\title{
Condições de vida dos catadores de caranguejos: uma proposta de educação ambiental em Vitória - (ES)
}

Rozangela Pereira Marins

Dissertação apresentada ao Programa de Pós-Graduação em Saúde Pública da Faculdade de Saúde Pública da Universidade de São Paulo para obtenção do título de Mestre em Saúde Pública.

Área de concentração: Serviços de Saúde Pública

Orientador: Prof. Dra. Maria Cecília Focesi Pelicioni

\section{São Paulo}

2005 


\section{$45655 / 2005 d x$}

Autorizo, exclusivamente para fins acadêmicos e científicos, a reprodução total ou parcial desta dissertação, por processos fotocopiadores. Ao usá-lo, cite a fonte.

Assinatura:

Data: 
Aos meus pais, Pedro Gonçalves Pereira e Elenita Lima Pereira pelo apoio, força, carinho, ajuda, compreensão e incentivo em todos os desafios da minha vida. 


\title{
AGRADECIMENTOS
}

Os meus sinceros agradecimentos a Professora Doutora Maria Cecília Focesi Pelicioni pela orientação prestada e pelo incentivo permanente na realização deste trabalho acadêmico.

\begin{abstract}
À André Gustavo Nunes que com dedicação, possibilitou a realização do estudo de campo, contribuindo com inúmeras sugestões e material bibliográfico para a concretização deste programa de mestrado.
\end{abstract}

A Associação Educacional de Vitória (FAESA Campus II) pela oportunidade e ajuda financeira oferecida.

As equipes de campo e gabinete, Amanda, Bruno, Danielle, Giselle, Jorge, Leonardo, Ludmilla, Márcio, Meryhelen, e Roger, pela dedicação, esforço e imprescindivel ajuda na coleta, análise e organização dos dados, sem os quais este trabalho não teria sido, de modo algum, possivel.

A professora Eliete Rabi Bortolini, diretora de Faculdade de Saúde e meio ambiente, pela sugestão na escolha da população de estudo e incentivo.

Aos catadores de caranguejo, do Município de Vitória, pela ajuda no levantamento dos dados e por acreditar no meu trabalho e proposta.

Ao meu querido marido, Luciano pela amizade e companheirismo durante todo o curso.

As minhas maravilhosas filhas, Danielle e Giselle, pela ajuda e incentivo.

Ao professor João Sossai pela ajuda, disponibilidade, sugestões, apoio, colaboração pessoal e pela paciència que dispensou a minha pessoa, durante todo o curso. 
Aos professores Marcos Reigota e Araci Witt de Pinho Spinola, que com sugestões colaboraram para a realização desta dissertação.

Ao meu sogro, Nilo Cardoso Marins (in memorian) pela torcida e incentivo para finalizar esta dissertação.

A todos que participaram direta ou indiretamente do meu trabalho, meus sinceros agradecimentos. 


\section{RESUMO}

\section{MARINS RP. Condições de vida dos catadores de caranguejos do município de}

Vitória - (ES). São Paulo; 2005. [Dissertação de Mestrado - Faculdade de Saúde Publica da Universidade de São Paulo].

A presente pesquisa, foi realizada no município de Vitória (ES), com a participação de 100 catadores de caranguejos, que atuavam diretamente nessa atividade. Teve como objetivo realizar a caracterização sócio-econômica-cultural e ecológica dos catadores de caranguejos, avaliar os agravos de saúde decorrentes das atividades desenvolvidas e levantar aspectos relacionados à captura do caranguejo que interferem no meio ambiente, visando a conservação do ecossistema manguezal do Município de Vitória. Para a coleta dos dados foram utilizadas entrevistas com formulários contendo questões abertas e fechadas para levantamento dos dados pessoais, familiares e profissionais dos catadores de caranguejo e entrevista com anamnese para levantamento e fichamento dos dados sobre a saúde dos catadores de caranguejo. Entre os resultados obtidos destacam-se a composição do grupo, que era composto exclusivamente por homens, as faixas etárias mais significativas foram entre 28 e 38 anos (38\%) e eram também os que detiam a experiência, "o saber popular" e portanto sob este aspecto podem ser considerados como a "população tradicional dos mangues". Grande parte das queixas verificadas durante a avaliação fisica estão diretamente relacionadas com o esforço despendido na locomoção, captura e transporte dos caranguejos dentro do manguezal. Constatou-se o desconhecimento sobre os cuidados básicos da higiene bucal (95\% apresentaram doença periodontal). Em relação ao exame audiométrico 3 (7,5\%) apresentaram uma perda auditiva significante, que pode estar associada à utilização de óleo diesel (solvente) no corpo. O resultado do estudo contribuirá, na implantação de medidas efetivas de gestão compartilhada para o município de Vitória, utilização sustentada de seus ecossistemas e melhoria das condições de vida dos catadores de caranguejos.

Palavras-chave: catadores de caranguejo; promoção da saúde; educação ambiental; sustentabilidade 


\section{SUMMARY}

\section{Living conditions of the crab catchers in the municipal district of Vitória, state}

of Espírito Santo. São Paulo; 2005. [Master Dissertation - Faculdade de Saúde Pública da Universidade de São Paulo].

The present work, carried out in the municipal district of Vitória, state of Espírito Santo, counted with the participation of 100 crab catchers that directly practice their working activity. Its main objectives were to search for the social, economical, cultural and environmental characteristics of those workers, evaluate the problems derived from the activity they perform, and point out aspects related to the catching of crabs that interfere in the environment. These objectives aimed to keep the marsh ecosystem of the municipal district. The data collection was done through interviews during which a questionnaire containing open and closed questions was answered. Its objective was to survey personal, familiar, and professional information about those workers. In addition to that, an interview with anamnesis was carried out in order to keep their files and health state. Among the findings the group composition could be pointed out. It was exclusively composed by men with the age ranging from 28 to 38 years (38\%), and those were the ones with much experience - they can be considered "the traditional marsh population" according to a popular saying. Most of the complaints registered during the physical evaluation were directly related to the strength used in the moving, catching and transportation of the crabs in the marshes. There was no knowledge about basic oral hygiene $(95 \%$ presented Periodontal Disease). As for the Audiometric Exam, 3 catchers (7.5\%) showed significant hearing loss, what could be associated to the use of diesel oil (solvent) in the body. Those findings will contribute to the implementation of effective measures of sharing management for the district, to the sustainable use of its ecosystem and resources, as well as to the improvements of the crab catchers' living conditions.

Key words: crab catchers; health promotion; environmental education; sustainability 


\section{ÍNDICE}

1) INTRODUÇÃO 20

1.1 A Gestão ambiental no Gerenciamento Integrado da Zona Costeira 23

1.2 A Gestão Compartilhada 25

2) CARACTERIZAÇÃO DO AMBIENTE DE MANGUE 28

3) UTILIZAÇÃO DA FAUNA DO MANGUEZAL COMO FONTE DE ALIMENTO COM ÊNFASE NO CARANGUEJO - UÇÁ (UCIDES CORDATUS)

4) A ETNOGRAFIA DOS CATADORES DE CARANGUEJO

5) A TEORIA DA EDUCAÇÃO AMBIENTAL E A SAÚDE PÚBLICA

6) O PROCESSO EDUCATIVO VISANDO AO DESENVOLVIMENTO DA SUSTENTABILIDADE

7) OBJETIVOS 57

$\begin{array}{lll}7.1 & \text { Objetivo geral } & 57\end{array}$

$\begin{array}{ll}7.2 \text { Objetivos específicos } & 57\end{array}$

8) LOCALIZAÇÃO E CARACTERIZAÇÃO DA ÁREA DE ESTUDO $\quad 58$

9) METODOLOGIA 60

$\begin{array}{ll}9.1 \text { População de estudo } & 60\end{array}$ 
9.2 Material e métodos 60

9.3 Pré-teste 65

9.4 Aspectos Éticos da Pesquisa 65

10)APRESENTAÇÃO E DISCUSSÃO DOS RESULTADOS 66

10.1 Descrição da população do estudo 66

10.2 Envolvimento da população em estudo nessa atividade $\quad 86$

10.3 Conseqüências ambientais 95

10.4 Agravos à saúde dos catadores $\quad 99$

11)CONCLUSÕES 113

12)CONSIDERAÇÕES FINAIS 118

13)RECOMENDAÇÕES $\quad 120$

14)REFERÊNCIAS 122

ANEXOS

Anexo 1 - Roteiro de entrevista

Anexo 2 - Ficha clínica interdisciplinar

Anexo 3 - Termo de consentimento

Anexo 4 - Entrevistas espontâneas 


\section{LISTA DE TABELAS}

Tabela 1 - Distribuição do número e da porcentagem dos catadores de caranguejos do município de Vitória por bairros

Tabela 2 - Distribuição do número e da porcentagem dos catadores de caranguejos segundo a idade

Tabela 3 - Número e percentagem dos catadores de caranguejos segundo o estado civil

Tabela 4 - Distribuição da situação e percentagem do trabalho das esposas/companheiras

Tabela 5 - Distribuição do número e percentagem dos catadores de caranguejos segundo a escolaridade

Tabela 6 - Distribuição do número de percentagem de catadores de caranguejos segundo o tempo de residência no local do estudo

Tabela 7 - Condições de moradia e ambientais dos catadores de Caranguejos

Tabela 8 - Número de catadores de caranguejo segundo tempo de trabalho no mangue

Tabela 9 - Número de catadores de caranguejos de acordo com a quantidade de dias trabalhados

Tabela 10 - Distribuição do número de catadores por dia da semana trabalhada

Tabela 11 - Distribuição do número dos catadores de caranguejos segundo a quantidade de dúzias coletadas

Tabela 12 - Quanto ao número de catadores atuando na região. 


\section{LISTA DE FIGURAS}

Fig. 01 - Região Metropolitana da Grande Vitória 59

Fig. 02 - Residência - bairro Maria Ortiz (Grande Vitória) 79

Fig. 03 - Destaque da cozinha bairro (Grande Vitória) 83

Fig. 04 - Distribuição dos catadores de caranguejos segundo a renda familiar média

Fig. 05 - Técnicas utilizadas para a captura do caranguejo-uçá (ucides cordatus) no município de Vitória

Fig. 06 - Quanto à utilização do caranguejo para o consume próprio no município de Vitória

Fig. 07 - Pescadores que coletam outros mariscos no município de Vitória

Fig. 08 - Quanto ao registro em órgãos ou entidades ligados à cata do caranguejo no município de Vitória

Fig. 09 - Caminhada na floresta do mangue

Fig. 10 - Retorno para o bote após uma entrada no mangue

Fig. 11 - Captura do caranguejo "no braço"

Fig. 12 - Transporte dos caranguejos

Fig. 13 - Amarração dos caranguejos

Fig. 14 - Catador com o frasco para transporte de óleo diesel amarrado à cintura 


\section{APRESENTAÇÃO}

A discussão sobre os temas saúde e ambiente mobiliza a sociedade como um todo, após acompanhar episódios como as grandes guerras mundiais, os campos de concentração, a fome, os conflitos no Oriente Médio, as experiências com genomas, as armas químicas $\mathrm{e}$ as agressões ao meio ambiente, situações muitas vezes vivenciadas, também, pelos meios de comunicação de massa.

Não se pode e não se deve agir como se a saúde fosse um bem comerciável e de responsabilidade apenas de profissionais que se dedicam a estudar o funcionamento do organismo humano. A saúde é um bem a ser mantido por ações cada vez mais integradas e assumidas enquanto responsabilidade coletiva

A ausência de "doenças" - leva-se em consideração que estas são classificadas e identificadas não por quem as sofre, mas por quem as "conhece" não é suficiente para garantir o estado saudável de uma pessoa. Pensar, portanto, em saúde somente no aspecto "curativo" é um ledo engano e uma demonstração de ingenuidade perigosa. Também não se pode acreditar que a "prevenção", pensada apenas no sofrimento enquanto alteração de funcionamento de um organismo vivo, é eficiente quando se detém em estudos fundamentados em patologias surgidas no aspecto "macrossocial".

Pensa-se a saúde como condição de vida, pode-se entendê-la, como política, o que leva a discussões que vão desde à educação básica formativa até a dotação orçamentária dos governos. Precisa-se pensá-la como atitude coletiva no sentido de construir condições favoráveis a qualquer forma de vida, potencializam-se os recursos naturais disponiveis ao consumo universal, administram-se os recursos financeiros de modo a reduzir as injustiças sociais.

Precisa-se assegurar os espaços para pensar em projetos pela defesa da vida com dignidade, com eqüidade de direitos, com acessibilidade aos serviços 
disponíveis e com maior condição de prover as próprias necessidades com autonomia, pela redução das desvantagens sociais.

Atua-se há 9 anos na educação superior especificamente na área social, na região da Grande São Pedro, em Vitória do Estado do Espírito Santo, Brasil, que um dia foi chamado de "lugar de toda pobreza". Durante algum tempo, a população conviveu com o lixo, usado como aterro para aumentar o espaço urbano.

A problemática das comunidades carentes sempre foi uma questão que me sensibilizou, atuando por várias vezes como voluntária na tentativa de diminuir a exclusão social.

Minha vocação para a área social ocorreu desde o último ano da graduação em Administração de Empresas, na Universidade Federal do Espírito Santo - UFES, onde o trabalho que apresentei de monografia, abordava a educação como meio de transformação da sociedade com enfoque na saúde e no meio ambiente. Antes de iniciar na área educacional, tive o privilégio de atuar em outros setores, onde pude conviver com diferentes realidades sociais. Essas experiências foram essenciais para minha formação profissional e pessoal.

Em 1996, ao iniciar minhas atividades como colaboradora da Associação Educacional de Vitória, mantenedora da então Faculdade de Comunicação e Educação situada no bairro São Pedro, município de Vitória, Brasil, como assessora administrativa, tracei um diagnóstico dos problemas sociais emergentes da área, como forma de identificar minhas possibilidades de atuação para contribuir para a melhoria de vida daquela comunidade.

As minhas pretensões naquela comunidade foram concretizadas, quando constatei que o grande foco de ação da FAESA é a área social, que apresenta como missão, "Promover o desenvolvimento social por meio do conhecimento". A ação educacional da FAESA tem como propósitos: a crescente melhoria da qualidade de vida dos seres humanos; o desenvolvimento da educação como fator de 
transformação social; a formação de cidadãos competentes que saibam, conceber e fazer, conviver, ser, agir, pensar e atuar prospectivamente.

Participei de várias intervenções no bairro São Pedro, entre elas podem ser citadas: a melhoria do muro que separa a comunidade da FAESA, algumas casas foram edificadas com o aproveitamento do muro da Instituição, sendo que o mesmo não seria calculado para suportar o peso que era colocado sobre ele. Antes que uma tragédia acontecesse, providenciou-se a construção de um outro muro pelo lado de dentro do terreno da FAESA, para servir de apoio a estas residências. É sabido que o saneamento básico é um grande desafio para a saúde pública, mesmo com toda a infra-estrutura implantada pela Prefeitura Municipal de Vitória, a maioria das casas ainda não está interligada à rede pública. Ao constatar o problema, a FAESA contratou profissionais e adquiriu os materiais necessários para levar o esgoto das casas do entorno da FAESA até a rede pública e a construção de banheiros para a melhoria das condições de vida dessa comunidade, antes disso, os resíduos físiológicos dos moradores eram depositados em sacolas plásticas e descartadas a céu aberto. A proteção do manguezal no entorno da FAESA foi intensificada.

Em 1997, iniciou-se a construção e a implantação da Faculdade de Odontologia. $\mathrm{O}$ projeto pedagógico do Curso de Odontologia, da FAESA, apresentava como principal atributo seu caráter inovador e ousado,em um contexto de formação profissional em que era evidente e notória sua morosidade em enveredar por um caminho que a levasse à modernidade demandada pela evolução científica e tecnológica da odontologia nas últimas décadas.

Durante a implantação da Faculdade de Odontologia ficou sob minha responsabilidade a implantação e supervisão da montagem dos laboratórios e clínicas para o funcionamento do curso. Foi nessa época que iniciei um curso de atualização na área de Educação em Saúde, em que obtive contato com os conceitos e estratégias da promoção em saúde 
Em 1998, viveu-se um novo momento, com o início da Faculdade de Ciências da Saude de Vitória, cuja origem esteve intimamente ligada ao projeto de criação do Curso de Odontologia. Constitui-se uma das metas alcançadas nos dias atuais, pelo planejamento global de uma instituição que representa, no contexto do ensino superior do Espírito Santo, um papel de significativa relevância no âmbito da formação de profissionais da área da saúde do Estado.

Os demais cursos aprovados e implantados a seguir, Enfermagem e Terapia Ocupacional em 2000/2, Ciências Biológicas, Educação Física e Fonoaudiologia em 2001/1, e mais recentemente Nutrição e Psicologia em 2002/1 foram fundamentados pela mesma filosofia do Curso de Odontologia e favoreceram o estabelecimento de um sistema que atende aos princípios primordiais do ensino superior na área da saúde: ensino, pesquisa e prestação de serviços de saúde - de caráter educativo, preventivo e curativo - em consonância com o já estabelecido pelo setor público e privado da região em que está localizada a instituição. Atuei diretamente na construção, aprovação e implantação dos cursos de graduação em saúde da FAESA.

Essa experiência foi fundamental para um envolvimento profissional mais efetivo nos vários projetos que já existiam e naqueles que foram implantados a partir do início das atividades dos cursos de graduação da Faculdade de Saúde. Um deles, o Projeto São Pedro na Ponta do Lápis, executado entre 2002 e 2003, traduz a responsabilidade social da FAESA não só com a excelência do ensino, mas também com a melhoria da qualidade de vida da comunidade em que se insere, além de seu compromisso com a inclusão social.

Desta forma, este projeto não se traduz somente em alfabetização de jovens e adultos, mas em formação de cidadãos. Para tanto, envolveram-se oito cursos da Instituição na elaboração de uma proposta conjunta.

Trabalham-se conteúdos de linguagem oral e escrita, alfabetização, matemática, artes, noções de informática, promoção à saúde e à formação do trabalhador, o projeto foi desenvolvido respeitando a especificidade do educando e 
construindo um espaço educativo que contribua para o enfrentamento dos desafios cotidianos dos trabalhadores não escolarizados.

Desde 2001, participo, como membro, da Comissão de Biossegurança, que tem como finalidade normatizar os procedimentos clínicos e laboratoriais, visando à prevenção de acidentes, à racionalização de tarefas e ao uso correto e adequado dos materiais nas clínicas e nos laboratórios da Faculdade de Saúde e Meio Ambiente. O protocolo de biossegurança vigente tem como objetivo primordial a proteção ao meio ambiente, a preservação da integridade física de alunos, funcionários, professores e todos os envolvidos no desenvolvimento das atividades clínicas e laboratoriais

De 2002 a 2004, participei da comissão de Processo Seletivo, na função de coordenadora operacional.

A produção vertiginosa do conhecimento nas diversas áreas do saber, a evolução nos hábitos, nos costumes e nos modos de vida da população determinam uma demanda, cada vez maior pelo trabalho em equipe

No contexto atual, nenhuma profissão, sobrevivendo isoladamente, consegue suprir os anseios de serviços e de produtos gerados pela sociedade nos seus diferentes setores. A rápida expansão e diversificação dos campos de trabalho dos profissionais da saúde, a crescente demanda pelos seus serviços, as contínuas e aceleradas transformações do conhecimento nessas áreas e as inovações tecnológicas delas decorrentes, bem como a crescente conscientização dos valores de cidadania, exigem das Instituições de Ensino atitudes cada vez mais agressivas, visando ao desenvolvimento das qualificações e das competências requeridas à sua intervenção nos diferentes contextos de sua atuação.

Hoje, colocam-se as tarefas de formar profissionais mais capacitados a tomar decisões assumindo riscos e consequeências e torná-los competentes para uma atuação profissional para que possam, efetivamente, participar de cada etapa do processo de 
prevenção, de promoção e de recuperação da saúde do individuo e da coletividade, em atividades inter e multiprofissionais.

$\mathrm{Na}$ área de saúde, o trabalho multiprofissional já é uma realidade em alguns programas governamentais, tal como: o Programa de Saúde da Família (PSF), em que estão envolvidos médicos, enfermeiros, nutricionistas, farmacêuticos, fisioterapeutas, terapeutas ocupacionais, psicólogos entre outros.

Todavia, o trabalho em equipe encontra-se ainda, incipiente em algumas instituições de atenção à saúde como Hospitais Públicos e Privados, Clínicas, Centros de Saúde, Ambulatórios e em outros serviços da área.

A razão disso está relacionada ao fato de que a articulação entre o saber e o fazer em algumas equipes multiprofissionais tem se dado, somente no momento da prática, isto é, os profissionais envolvidos não desenvolvem durante a sua formação as habilidades necessárias para um trabalho interprofissional o que acaba por agravar os transtornos e dificuldades inerentes à própria prática.

A FAESA atenta a essa questão, apresenta na concepção e na implementação de seus cursos da área de saúde uma proposta ousada e inovadora, em que o pensar e o fazer andam juntos. Implanta a Clínica Integrada, a partir de uma proposta institucional na formação profissional na área de saúde, em que a visão holística da abordagem e os cuidados dos agravos que acometem individual e coletivamente a população representam uma opção e a base de uma filosofia, e tem como propósitos: a construção de uma prática moderna de atenção à saúde; a busca de uma adequada articulação entre os cursos de graduação e a participação ativamente do contexto de atenção à saúde já estabelecido na comunidade.

Em 2002/2, a direção da Instituição solicitou um estudo para ver a viabilidade do funcionamento dos cursos da FAESA - Campus III, nas instalações do Campus II. Nos dias atuais, não se concebe a separação dos efeitos de fatores ambientais sobre a saúde da população. Segue-se esse raciocínio, a partir de 2003, os cursos de 
Engenharia Ambiental, Licenciatura em Química e Agronomia passam a funcionar no Campus II da FAESA, utilizando a estrutura física da Faculdade de Saúde, que mais tarde passou a se chamar Faculdade de Saúde e Meio Ambiente.

Com a confirmação da possibilidade de realizar o mestrado na Faculdade de Saúde Pública, inicialmente pensei em dar continuidade ao trabalho que realizava junto às crianças, no morro do Jaburu, Vitória- ES, como voluntária, mas como esta comunidade ficava distante da Instituição, onde sou colaboradora, resolvi trabalhar com uma comunidade mais próxima em que pudesse agregar valores à saúde e ao meio ambiente.

A escolha da população alvo recaiu sobre os catadores de caranguejos do município de Vitória, levada pela responsabilidade social e pelo compromisso profissional com os excluidos.

Contribuiu ainda mais para a escolha das comunidades dos catadores de caranguejos, o sentimento que me despertou ao me deparar com as condições de vida a que se submetem esses indivíduos.

O capitulo dois faz uma análise histórica das citações, sob diferentes aspectos, relacionados ao valor do manguezal e à ocupação desordenada dele.

O terceiro capítulo mostra a evolução histórica da utilização da fauna do manguezal como fonte de alimento com ênfase no caranguejo-uçá (ucides cordatus). Já o quarto capítulo trata da caracterização dos catadores de caranguejos e seus saberes.

O capítulo cinco faz uma análise histórica sobre as concepções da teoria da educação ambiental relacionada à saúde pública, com a finalidade de servir de contexto para um maior entendimento sobre a emergência da questão ambiental no âmbito global. 
O capítulo seis apresenta uma análise histórica do processo educativo visando ao desenvolvimento da sustentabilidade, ou seja, noções que possam nortear processos de sensibilização ambiental, para que sejam construídas representações sociais globalizantes de meio ambiente. Além de considerações sobre as limitações do termo desenvolvimento sustentável.

No capítulo sete, apresentam-se os objetivos da pesquisa. O capitulo posterior cita-se a localização e a caracterização da área de estudo e a seguir, descrevem-se as considerações metodológicas da pesquisa.

A apresentação e discussão dos resultados estão no capitulo dez, expostos conforme o roteiro de entrevista. A partir daí, foi possível chegar-se às conclusões de que estão no capítulo onze. No capítulo doze, foram expostas às considerações finais, e a seguir as recomendações com algumas sugestões de melhoria na condição de vida dos catadores de caranguejos do Município de Vitória. 


\section{INTRODUÇÃO}

O conflito de relacionamento do homem com a natureza, acentuado com o advento da tecnologia, reclama por uma nova consciência ecológico-ambiental e por uma nova postura ética da humanidade perante ao meio ambiente, patrimônio de todos. A exploração indiscriminada e predatória do meio ambiente pode colocar em risco a própria sobrevivência da espécie humana. Trata-se de administrar bem tal patrimônio. E, para isso, são necessários conhecimentos específicos acerca das interrelações que se dão no ambiente global. É necessário o desenvolvimento de valores sociais e de atitudes de respeito, que são, fundamentalmente, tarefas da educação. $O$ processo educativo e, especificamente, a educação ambiental, para ser eficaz não pode focalizar apenas os aspectos cognitivos, ser desvinculada da realidade, mas também, deve ser vivencial e voltada para a ação e para a solução dos problemas, para a proteção e para a defesa do meio ambiente.

O valor dos ecossistemas costeiros é bastante conhecido, por estes servirem de áreas de criação, refúgio, fonte de nutrientes, responsáveis por parte considerável dos recursos marinhos. A degradação desses locais, devido à poluição industrial e à doméstica, à especulação imobiliária, à falta de planejamento e à falta de políticas para a exploração sustentada, diminui a disponibilidade das populações de espécies exploráveis (NEIVA 1990) causando problemas financeiros, econômicos e sociais para as comunidades de cuja subsistência depende esses locais.

No Brasil, várias capitais de Estados e Territórios, além de importantes cidades, estão situadas em ecossistemas estuarinos. Vitória, no Estado do Espírito Santo, está incluída entre essas capitais. Originalmente, a maioria dos terrenos que compunha a parte plana de Vitória era coberta por mangues. Como a cidade fica localizada entre a montanha e o mar, o crescimento da área física foi feito por meio de sucessivos aterros de mangues e de praias, o que ocorre desde o século passado (CARMO 1987). 
Várias pesquisas têm relatam os problemas da cata do caranguejo e das comunidades catadoras encontradas nas regiões dos manguezais, no município de Vitória (TRISTÃO 1992; VALE 1993; CARMO 1995; ALVES 2004). Essas pesquisas descrevem problemas que permeiam a atividade da cata do caranguejo nos manguezais da Baía de Vitória, tais como, a captura desordenada para garantir a sobrevivência, os desmatamentos, os aterros, além da retirada do córtex de $R$. Mangle, planta característica do mangue, para extração do tanino, causando a redução da área de manguezal. O tanino é um composto orgânico de natureza glicosídica, bastante adstringente, utilizado, principalmente, em curtumes e para tingir cordas e redes de pescadores, dando maior resistência a esses materiais (HILL 1974).

Em seqüência a esses trabalhos, foi proposto o desenvolvimento de um grande projeto de pesquisa, envolvendo questões ligadas à preservação das áreas de restinga ao longo da costa do Estado do Espírito Santo. Esse projeto, denominado "Projeto Caranguejo: Bioecologia do Caranguejo Ucides cordatus e caracterização sócio-econômica e de saúde dos catadores de caranguejo no Espírito Santo" (2000), foi desenvolvido em parceria com as prefeituras Municipais de Anchieta, Aracruz, Conceição da Barra, Guarapari, Serra e Vitória, Instituto Brasileiro do Meio Ambiente e dos Recursos Naturais Renováveis (IBAMA), Secretaria de Estado de Meio Ambiente e de Recursos Hídricos (SEAMA), Instituto Nacional do Seguro Social (INSS), Delegacia Regional do Trabalho e Emprego (DRTE), Capitania dos Portos, Associação dos Marisqueiros e dos Pescadores dos Municípios da Grande Vitória, Colônias de Pescadores do Espírito Santo, Federação dos Pescadores do. Espírito Santo, Universidade Federal do Espírito Santo (UFES) e Fundação Ceciliano Abel de Almeida (FCAA).

A região noroeste da Ilha de Vitória ainda contempla uma extensa área verde. De um lado, o maciço central, com trechos em que a paisagem natural sofreu a intervenção humana. De outro lado, a Estação Ecológica Municipal Ilha do Lameirão, com seus 893 hectares de manguezal preservados. 
Considera-se a relevância da atividade da cata do caranguejo não apenas pelo seu caráter econômico, enquanto atividade produtiva provedora de renda a um significativo número de famílias, assim como para outros segmentos, indiretamente envolvidos com a mesma atividade em todo o município de Vitória, mas também, pelo aspecto cultural e histórico que a cata do caranguejo representa dentro do contexto nacional, estimularam o desenvolvimento da presente pesquisa, que propôs ações integradas de forma participativa, no processo de gestão dos recursos ambientais existentes no município de Vitória.

O processo de gestão compartilhada dos recursos permite às comunidades de pescadores artesanais operar em co-responsabilidade com o Estado, estabelece parceria, em que a atividade produtiva e o respeito à natureza são observados. Esse fato, além de legitimar as medidas que estabelecem critérios para o uso sustentado dos recursos ambientais facilita a organização da categoria profissional.

A implementação de um processo de gestão ambiental, só será possível com a obtenção de um diagnóstico prévio. A partir do diagnóstico de base realizado, será possível determinar um perfil das exigências e os problemas de ordem social, econômica e ambiental necessários para a criação de um Fórum de Gestão Compartilhada base para a sustentabilidade do ecossistema, das comunidades e sua cultura.

A presente pesquisa, envolvendo apenas o município de Vitória, constitui parte do "Projeto Caranguejo" e poderá servir de referência para outros municípios que fazem parte do mesmo. Além de uma iniciativa que busca operacionalizar princípios relacionados à promoção da saúde e ao desenvolvimento sustentável, mediante à proteção ao meio ambiente, seus resultados poderão ser utilizados para promover melhoria das condições de vida e ambientais, o desenvolvimento social e econômico e a dignidade humana, conforme recomenda a agenda 21, aprovada durante a Conferência das Nações Unidas sobre o Meio Ambiente e Desenvolvimento (Rio - 92), realizada no Rio de Janeiro em 1992. 


\subsection{A Gestão ambiental no Gerenciamento Integrado da Zona Costeira}

A Constituição Federal brasileira considera a Zona costeira como "patrimônio nacional", devendo ser utilizada observando a conservação do meio ambiente (art. $\left.225 \S 4^{\circ}\right)$.

Por sua vez a Lei 7661, de 16.5.88, que instituiu o Plano Nacional de Gerenciamento Costeiro (PNGC) definiu em seu art. $2^{\circ}$, parágrafo único, a Zona Costeira como "o espaço geográfico de interação do ar, do mar e da terra, incluindo seus recursos renováveis ou não, abrangendo uma faixa marítima e outra terrestre, que serão definidas pelo Plano". E em seu art. $3^{\circ}$, 1 , dá prioridade à conservação e proteção, em caso de zoneamento, entre outros, aos manguezais, prevendo, inclusive, sensações como interdição, embargos e demolição (art. $6^{\circ}$ ), além das penalidades do art. 14 da Lei 6.938/81, que instituiu a Política Nacional do Meio Ambiente.

Esse Plano Nacional de gerenciamento Costeiro foi aprovado pela Resolução $\mathrm{n}^{\circ} 01$ de 21.11.90 da Comissão Interministerial para os Recursos do Mar (CIRM) e pelo CONAMA - Conselho Nacional do Meio Ambiente e define a Zona Costeira como "a área de abrangência dos efeitos naturais resultantes das interações terra-marar, leva em conta a paisagem físico-ambiental, em função dos acidentes topográficos situados ao longo do litoral, como ilhas, estuários e baías, comporta em sua integridade os processos e interações características das unidades ecossistêmicas litorâneas e inclui as atividades sócio-econômicas que aí se estabelecem (Machado, 1992).

Em alguns Estados maritimos brasileiros pode-se constatar que na Constituição desses há expressa referência à preservação dos mangues, como na constituição dos Estados da Bahia, Ceará, Maranhão, Paraíba, Piauí e Rio de Janeiro. No restante dos Estados marítimos, os manguezais existentes em suas áreas estão de certa forma protegidos, porque em suas Constituições há dispositivos legais que protegem regiões que têm flora e fauna rica ou de importância, estando por conseguinte incluídos aí os mangues, de forma que os manguezais brasileiros estão 
bem definidos e incluídos na Zona Costeira do Brasil, e conseqüentemente protegidos por lei, quer expressamente quer indiretamente.

$\mathrm{O}$ art. 225, caput, da Constituição Federal, garante a todos o direito ao meio ambiente ecologicamente equilibrado, impondo ao Poder Público e à coletividade o dever de defendê-lo e preservá-lo.

Assim, pelo fato de estar dentro da Zona Costeira, somado às suas características especiais em termos biológicos, o ecossistema manguezal está protegido legalmente contra a degradação, e em muitos Estados marítimos brasileiros, é considerado área de proteção permanente em suas Constituições.

Mas, apesar de toda essa legislação, os manguezais são aterrados para a expansão urbana, sofrem desastres ecológicos por derramamento de petróleo e sofrem poluição por lançamento de esgotos entre outros, é catastrófico e obviamente não são observadas as diretrizes legais.

A ocupação do entorno do município de Vitória e os diferentes aspectos que envolvem a exploração de seus recursos naturais indicam um processo acelerado de degradação do meio fisico natural e, conseqüentemente, o desequilíbrio do sistema, tudo isso só poderá ser controlado adequadamente por meio de planejamento estratégico de gestão.

Todavia, para ser possivel viabilizar a implementação de um processo de gestão ambiental, torna-se necessário à obtenção de um diagnóstico prévio, que permita verificar como a dinâmica ambiental se associa, em diferentes níveis, à interferência humana, ao diagnóstico sócio-econômico relacionado à percepção ambiental das comunidades envolvidas, no caso, os usuários potenciais dos recursos naturais (caranguejos) representam um passo fundamental de qualquer proposta de gestão sustentada. 
A partir do diagnóstico de base realizado, será possível determinar um perfil das exigências e problemas de ordem social, econômica e ambiental necessárias para a criação de um Fórum de Gestão Compartilhada, base para a sustentabilidade do ecossistema garantia de respeito e cultura das comunidades.

\section{2 - A Gestão Compartilhada}

Pelo exposto, a gestão ambiental envolve, por principio, o processo participativo em todas suas etapas, desde o planejamento até as ações efetivas. Por participativo, entende-se ser o processo em que os indivíduos de diferentes setores da sociedade contribuem de alguma forma na sua consecução, assumindo, de forma compartilhada, os direitos, as responsabilidades, os problemas e os esforços advindos de sua implementação.

SAJISE (1995), descreve a gestão compartilhada como um processo, em que as próprias pessoas têm a oportunidade e/ou responsabilidade de manejar os próprios recursos, definindo suas necessidades, metas, aspirações, para tomar decisões que afetam seu bem estar. $\dot{E}$ inerentemente, portanto, evolucionário, participativo, localizado e considera fatores técnicos, sócio-culturais, econômicos, políticos e ambientais. Pode-se dizer que é basicamente, uma autorização comunitária para o uso do recurso, visando à produtividade, à sustentabilidade e à eqüidade.

De acordo com a definição proposta acima, o Projeto São Pedro Desenvolvimento Urbano Integrado e Preservação do Manguezal em Vitória (ES) é uma empreitada coletiva, em que governo e sociedade civil organizada estão juntos desde o planejamento até a manutenção das obras e serviços implementados, cujos pontos básicos eram a delimitação e preservação da área de manguezal não devastada e a urbanização dos locais já ocupados por moradores. Os moradores foram informados sobre a importância de se preservar o manguezal e sobre os benefícios do projeto para a vida da comunidade, que participaria da definição e implementação das ações. Estavam previstas obras como aterro, abertura de ruas, calçamento, esgoto, instalação de água e luz, construção de creche e área de lazer. Em lugar de se 
abrir um canal para delimitar a área que seria preservada, a opção acabou sendo pela criação de uma área de uso público, com equipamentos esportivos, culturais e de lazer.

De acordo com POMEROY (1998), a implementação da gestão participativa comunitária opera quatro componentes: manejo dos recursos, desenvolvimento sócio-econômico, capacidade de suporte e suporte institucional. Envolve várias parcerias, "acordos e graus de poder compartilhado". Constitui-se na integração do local (costumes, histórias, tradições) com os sistemas de administração do governo centralizado. Não deve ser encarada como uma técnica administrativa flexível, na qual um fórum ou estrutura age na participação, confecção de regras, administração de conflitos, divisão de poderes, lideranças, diálogo, tomada de decisões, geração e divulgação de conhecimentos.

A grande dificuldade encontrada na difusão de experiências de gestão compartilhada é a baixa credibilidade do poder público, seja no âmbito municipal, estadual ou federal. Neste caso é preciso trabalhar a idéia de que a gestão compartilhada precisa ser uma conquista da sociedade, ou seja, uma ampliação da esfera pública, uma forma de radicalizar a democracia, ampliando as possibilidades de participação e controle social na gestão daquilo que é de interesse público.

Segundo SMITH (1982), o elemento chave para a viabilização de uma administração de recursos pesqueiros, em beneficio não de poucos, mas da sociedade como um todo, é a participação das comunidades locais nas decisões administrativas, bem como na sua execução. Isso permitiria a adequação das medidas às condições localmente vigentes, sua legitimidade junto às comunidades pesqueiras e fiscalização permanente. Isto significaria mudar a preocupação, predominantemente centrada na preservação do binômio pescador-recurso, ou seja, focalizar a interação, seu agente e receptor.

Os economistas, ao contrário, numa visão, estritamente disciplinar, só começaram a se interessar pelos problemas ligados à gestão dos recursos renováveis 
no transcurso da década de 50 e os primeiros modelos teóricos desenvolvidos durante a época, focalizavam, sobretudo, o setor da pesca. (GORDON 1954; SCHAEFFER 1957)

Muito embora o desenvolvimento posterior de pesquisas tenha produzido alternativas de análises mais dinâmicas, pluriespecíficas e capazes de internalizar a dimensão da incerteza sistêmica (CLARK 1990), a gestão de recursos renováveis continua, até hoje, a ser considerada por este grupo, como um problema que diz respeito, apenas, à exploração racional dos estoques.

No entanto, REVERET (1991), defende a visão de que os recursos renováveis implicam não só o conjunto, "in situ", dos elementos que se tornam objeto de exploração, mas também, o conjunto da cadeia trófica alimentar, necessária à continuidade da exploração. Trata-se, portanto, de assumir a postura, segundo a qual, o esforço de gestão relaciona-se não só à problemática de um recurso específico, mas também a um conjunto de mecanismos de reprodução do ecossistema considerado.

O estabelecimento e o sucesso da operação do processo de gestão compartilhada das pescarias, tendo em vista as diferentes percepções que norteiam a compreensão sobre o processo, podem ser um esforço complexo, custoso e de muitos anos e a diversidade biológica e sócio-cultural constituem um dos componentes básicos desta modalidade de gestão (POMEROY e WILLIAMS 1994).

Os maiores responsáveis pelo desenvolvimento de uma localidade, são as pessoas que nela vivem. Sem o interesse, o envolvimento, o compromisso e a adesão da comunidade local, nenhuma política de indução ou promoção de desenvolvimento alcançará êxito para obter esse nível.

Para obter esse nível de participação da comunidade local, é preciso adotar estratégias de planejamento e gestão compartilhada do processo de desenvolvimento. Tais estratégias permitem à comunidade local, por meio da experiência prática, o aprendizado necessário para que ela seja capaz de identificar potencialidades, 
oportunidades, vantagens comparativas e competitivas, problemas, limites e obstáculos ao seu desenvolvimento, a partir dos quais poderá escolher vocações, escolher vocações, estabelecer metas, definir estratégias e prioridades, monitorar e avaliar resultados, enfim, a capacitação requerida para planejar e gerenciar, de forma compartilhada, o processo de desenvolvimento local.

As estratégias de planejamento e gestão compartilhada, por serem participativas, contribuem para o crescimento do capital humano e do capital social, ampliando as possibilidades de controle da população local e facilitando a conquista da gestão governamental, que são algumas das condições necessárias para o desenvolvimento sustentável.

\section{CARACTERIZAÇÃO DO AMBIENTE DO MANGUE}

O valor do manguezal, sob diferentes aspectos, tem sido enfatizado, por diversos autores, desde épocas bastante antigas.

O mais antigo europeu a fazer citações a respeito desse ecossistema foi o padre José de Anchieta, em famosa carta datada de maio de 1560, enviada ao Padre Diogo Leínes, em Roma. O documento cita com clareza os vários tipos de caranguejos, suas variedades e formas encontradas em São Vicente, litoral do atual Estado de São Paulo e outros estados brasileiros, inclusive o Espírito Santo (ANCHIETA 1984).

SOUZA (1971), por exemplo, nos seus tratados descritivos do Brasil, mencionou as árvores de mangue como madeira de boa qualidade e enalteceu o manguezal como importante produtor de alimentos.

LUEDERWALDT (1919), em estudos realizados nos manguezais de Santos (SP), referiu-se detalhadamente à fauna e à flora dos mesmos, citando ainda sua importância econômica. 
O crescimento da consciência sobre a importância do ecossistema manguezal fez com que surgissem experiências de recuperação e preservação das áreas desmatadas de mangue.

A concepção de que o manguezal é um ambiente improdutivo, visto apenas como depósito de lixo e de moradia para as populações carentes, parece não ser mais aceitável. A importância do manguezal decorre principalmente de suas delicadas, complexas e essenciais relações internas e externas. Ele é agente emissor e receptor de nutrientes e de outros elementos importantes para o equilíbrio ambiental.

RUSCHI (1950), estudando a Fitogeografia do Espirito Santo, distribuiu os manguezais desse estado desde Conceição da Barra, ao norte, até o Rio Itabapoana, ao sul. Todavia, a maior extensão desta cobertura vegetal apareceu na Baía de Vitória. Já naquela época, esse eminente cientista chamava atenção para o desmatamento dos manguezais capixabas. Da área privativa, por ela calculada em torno de $850 \mathrm{Km}^{2}$, só restavam, em 1948, cerca de $500 \mathrm{Km}^{2}$. Os principais impactos antrópicos citados pelo autor estavam relacionados à urbanização, extração de madeira e exploração de tanino. RUSCHI (1969), voltou a analisar a devastação dos manguezais capixabas, avaliando para os mesmos, no referido ano de publicação do trabalho, uma área de apenas $100 \mathrm{Km}^{2}$, ao contrário de 1948 , com $500 \mathrm{Km}^{2}$ e uma área original avaliada em $850 \mathrm{Km}^{2}$, como apresentado anteriormente.

RUSCHI (1979), deu mais uma valiosa contribuição ao estudo dos manguezais capixabas. Além de tecer comentários a respeito das espécies vegetais aí encontradas, ele dedica mais atenção à fauna, principalmente às aves, aos répteis e a alguns mamiferos. RUSCHI (1986), mais uma vez, avaliou a área ocupada pelos manguezais no litoral capixaba, considerando agora um total de apenas $40 \mathrm{Km}^{2}$. SILVA (1986), avaliou a cobertura de manguezal ao longo do litoral capixaba em torno de $36 \mathrm{Km}^{2}$.

Segundo FERREIRA (1989), provavelmente o ilustre naturalista Augusto Ruschi tenha exagerado no levantamento dos dados relativos às áreas de vegetação 
$\left(850 \mathrm{Km}^{2}\right.$ de cobertura original, $500 \mathrm{Km}^{2}$ em 1948, $100 \mathrm{Km}^{2} \mathrm{em} 1969$ e $40 \mathrm{Km}^{2}$ em 1986), bem como toda evolução do desmatamento da mesma.

Relatos e material cartográfico antigos levam as pessoas a crer que a baía de Vitória sempre representou a maior concentração de manguezais capixabas, sendo inclusive os mais alterados e impactados do estado ao longo do tempo.

ANDRADE (1974), ao estudar a geografia econômica do Nordeste, analisou o extrativismo animal praticado nos ecossistemas litorâneos daquela Região. Dividiu essa atividade em duas categorias: caça e pesca. A pesca, por sua vez, foi subdividida em pesca de estuários, litorânea e em alto mar. $\mathrm{Na}$ pesca dos estuários, o autor salientou os manguezais como uma área extremamente rica para a coleta de crustáceos (caranguejos, moluscos e guaiamuns).

ANDRADE (1984), ao pesquisar a comunidade do Salgado (PA), coletou importantes $\mathrm{e}$ interessantes dados sobre o que ela chamou de "o folclore do manguezal". O trabalho pode ser considerado como uma significante análise da utilização da fauna do manguezal para a alimentação das populações ali residentes.

No Espirito Santo, os manguezais aparecem desde o extremo norte, até o extremo sul do Estado, com maior concentração na baia de Vitória. São observados em Conceição da Barra, Aracruz, Nova Almeida, Cariacica, Vitória, Vila Velha, Barra do Jucu, Serra, Guarapari, Anchieta, Piúma, Itapemirim e Presidente Kennedy.

O manguezal é área considerada intocável, protegida pela lei 4.771 desde 1965, mas na prática, isso não ocorre. As ameaças ainda são muitas, como a ocupação indevida por meio de aterro sanitário, desmatamento, poluição por resíduos industriais, uso inadequado dos recursos e invasão por comunidades carentes.

O municipio de Vitória (ES) teve grande parte de sua área aumentada por aterros nos manguezais. As ameaças do passado unem-se às do presente. A extração das cascas do mangue-vermelho para tingir as tradicionais panelas de barro, do 
artesanato capixaba, constitui-se em uma séria ameaça à integridade dos manguezais. Se a casca fosse extraída em tiras não causaria danos a Rizophora mangle, mas, por falta de cuidado e informação, derruba-se ou retira-se toda a casca em anéis, ocasionando o desaparecimento dos manguezais.

Em meados da década de 1960, a Universidade Federal do Espírito Santo UFES escolheu para a construção do Campus Universitário uma área de restinga e mangue situada nas margens da atual rodovia BR 101 - Norte, à época "estrada para a Serra", onde se localizava o antigo Victoria Golf \& Country Club, que foi solicitado ao Ministério da Educação e Cultura providências que permitissem a desapropriação daquela área. $\mathrm{O}$ decreto federal $\mathrm{n}^{\circ}$ 1.026-A declarava de utilidade pública a área do Victoria Golf \& Country Club para efeito de construção das unidades universitárias, autorizando que fosse promovida a sua desapropriação (BORGO 1995).

Incentivada pela instalação da UFES e do Complexo Portuário do Tubarão, a urbanização passou a exercer pressão no setor nordeste da ilha, em direção ao continente. Em 1965, processou-se a invasão e posterior aterro do atual bairro Andorinhas, com fixação de população pobre. Na mesma época, começou a ocorrer o desmatamento dos manguezais ao longo do Canal da Passagem, no seu trecho final em direção à Praia de Camburi, onde foram construidas algumas casas de alto padrão (FERREIRA 1989).

Em 1976, grande parte do lixo da Grande Vitória era depositado no manguezal a norte da Ilha, cujo aterro originou um bairro, hoje denominado Maria Ortiz. O local era o ponto de atração para as pessoas que retiravam do lixo restos de comida e materiais que comercializavam.

Essa situação durou até julho de 1978, quando a Comissão Nacional das Regiões Metropolitanas e Direitos Urbanos discutiu a destinação final do lixo domiciliar e o controle da poluição ambiental causada por esse material. O controle foi feito pela Capitania dos Portos, que ameaçava com multas quem fizesse aterro 
com lixo e defendia a construção de uma usina para beneficiamento dos resíduos sólidos. A construção da usina era um projeto defendido pelos técnicos, contrária a posição dos políticos e gerou desconfiança nos moradores. Em 1979, a Prefeitura Municipal de Vitória já procurava um novo terreno para deposição de resíduos sólidos.

Em 1980, o lixo foi deslocado para Carapina, no município da Serra, com a proposta de construir ali um aterro sanitário. Embora o lixão estivesse instalado no manguezal, que é domínio da União, a área foi reclamada por uma empresa que se dizia proprietária do imóvel, uma batalha foi travada com a vitória dos catadores de lixo que continuaram a tirar os seus proventos do lixo. Em seguida, a Prefeitura Municipal de Vitória protestou quanto à instalação do lixão em Carapina. Sem a construção da usina e a falta de um outro local, a Prefeitura Municipal de Vitória resolveu depositar o lixo urbano no bairro São Pedro III. Os catadores que atuavam em Maria Ortiz, e depois em Carapina, acompanharam a trajetória do lixo.

A história da ocupação da área de mangue, às margens da Rodovia Serafím Derenzi, iniciou em setembro de 1977, com cerca de quarenta famílias, ali instaladas precariamente em barracas de lona, barracos rústicos e coberturas improvisadas. Muitos conflitos sucederam durante o processo de ocupação, mas não impossibilitou aos moradores se organizarem, para garantir a ocupação.

A área do manguezal, de propriedade da União, foi aos poucos ocupada por famílias que se equilibravam em palafitas (casas de madeira sobre estacas), caracterizada por uma ocupação desordenada que acelerou a devastação do ecossistema manguezal.

A área passou a ser utilizada pela Prefeitura Municipal de Vitória para depositar todo o lixo produzido no município de Vitória, tanto lixo domiciliar como hospitalar transformando as áreas do mangue em lixões a céu aberto, que recebiam na época aproximadamente duzentos e trinta toneladas de lixo/dia. O lixo foi depositado nesse local a pedido dos moradores. Dois objetivos justificavam tal 
pedido. Primeiro, porque centenas de pessoas utilizavam o lixo como forma de obter renda para sua sobrevivência, seja com a venda de plásticos e de vidros, seja com o reaproveitamento de restos alimentares e peças de vestuário. Segundo, por se tratar de viabilizar para essas famílias o aterro do mangue com o próprio lixo e posterior cobertura com terra. Tal providência deveria ser tomada para proteção dos moradores, mas não ocorreu. Inicialmente, o aterro foi feito somente com o lixo (NOGUEIRA 1996).

MARIUS e colaboradores (1987), estudaram especificamente os solos de manguezais da baia de Vitória, classificando-os como uma formação geológica quaternária, de origem flúvio-marinha. VERGARA (1994), definiu poeticamente o manguezal como "fruto do namoro entre um rio e o mar".

Os pequenos canais de água, predominantemente salobra, mudam de forma, de acordo com a maré. Dominadora absoluta desse ambiente mutável, a maré influencia também a parte terrestre, constantemente alagada. É nesse cenário que surge um componente vital, tantas vezes apontado como responsável pela imagem feia ou suja do manguezal, a lama acinzentada.

A lama do manguezal é pura vida, rica em matéria orgânica, por meio da decomposição das folhas que caem das poucas espécies de árvores que sobrevivem na água salobra. A lama abriga e alimenta os caranguejos. Os caranguejos ajudam a oxigenar o solo, abrindo milhares de orificios, tornando o ambiente favorável também à sobrevivência do mangue.

FERREIRA (1989), elaborou uma tese acerca dos manguezais localizados no norte da baia de Vitória (ES), onde caracterizou a estrutura, função e distribuição geográfica dos mesmos, sob o prisma da geografia fisica integrada. Seu trabalho evidenciou a ocupação dos manguezais pelo descontrolado crescimento urbano, em prejuízo não só da fauna e da flora, como também de toda população de pescadores e catadores a eles relacionados. 
A luta pela sobrevivência dos manguezais se insere em um contexto internacional. A experiência de países que reduziram brutalmente a área desses ecossistemas não foi positiva. A destruição dos manguezais causou problemas de seca e incêndio na Flórida, sul dos Estados Unidos e enchentes na Índia.

Em contrapartida, desde 1991 já existem instituições trabalhando para o reflorestamento dos manguezais do mundo, como a Sociedade Internacional para Ecossistemas de Mangues (Internacional Society for Mangrove Ecossistems ISME), sediada em Okinawa, Japão. O primeiro projeto da Sociedade Internacional para Ecossistemas de Mangues foi implantado no sudeste da Ásia, mais precisamente na Tailândia, Malásia e Indonésia. O segundo projeto foi de mapeamento $\mathrm{e}$ reflorestamento para a América Latina e África e está sediado no Brasil, sendo iniciado em 1992.

\section{UTILIZAÇÃO dA FAUNA DO MANGUEZAL COMO FONTE DE ALIMENTO COM ÊNFASE NO CARANGUEJO - UÇÁ (UCIDES CORDATUS)}

Existem diversas espécies de caranguejo e siris nos manguezais da Baía de Vitória. Mas somente quatro são capturados e comercializados pelos catadores de caranguejos: o goiamum (Cardisoma guanuni), o aratu (Goniopsis cruentata), o siriaçu (Callinectes exasperatus), e o caranguejo (Ucides cordatus). Este último representa um dos recursos naturais mais explorados nos manguezais brasileiros. Embora existam outras espécies de crustáceos capturados e comercializados, o Ucides cordatus representa o centro das atividades dos caranguejeiros e é a espécie da qual dependem para sobreviver (ALVES 2004).

CARDIM (1980), referiu-se a várias espécies de caranguejos como deliciosa fonte alimentícia. CARRERA (1977), menciona a coleta de peixes, moluscos e crustáceos praticada pelos indigenas nos manguezais da América desde os primórdios da descoberta do Novo Mundo por Cristóvão Colombo. 
O caranguejo, Ucides cordatus, vive unicamente nos manguezais e pode ser encontrado no litoral brasileiro, desde Santa Catarina até o Amapá É um animal semi-terrestre, pois passa parte de sua vida (fase larvária) dentro d'água. Alimentase, principalmente, de folhas das árvores do mangue que caem na lama. Ao serem armazenadas nas tocas, as folhas são atacadas por fungos, entrando em processo de decomposição e transformando-se numa pasta recoberta de fungos. "Isso leva a supor que os caranguejos provavelmente se alimentam não das folhas e sim dos fungos ou das proteínas produzidas por eles" (NASCIMENTO 1993).

ARAÚJO e MACIEL (1979), classificaram os vários tipos de crustáceos encontrados nos manguezais da baia de Guanabara. AVELINE (1980), tratou do mesmo assunto, estendendo sua pesquisa a todo litoral brasileiro.

A exploração do caranguejo, Ucides cordatus, nos manguezais do Município de Vitória, ocorre de maneira intensiva e durante o ano todo. É realizada de forma indiscriminada e utiliza-se de técnicas predatórias, que causam não só prejuizos para a espécie como também para o ecossistema manguezal. A partir da década de 1980, as técnicas tradicionais de captura do caranguejo (braço, tapagem, cavadeira) foram substituídas pelo uso da "redinha" (armadilha confeccionada com fios de ráfia, amarrados nas extremidades), na maioria dos mangues brasileiros. Esse artefato é colocado na abertura da galeria do caranguejo, durante a baixa-mar, sendo fixado pelos catadores de caranguejo com pedaços de galhos ou rizóforos do mangue vermelho (Rhizophora mangle) (VERGARA 1994, apud, ALVES, 2004).

Os caranguejos, ao saírem das galerias, ficam presos às redinhas, facilitando a sua captura. Muitos deles não são coletados e acabam morrendo. Além disso, esse artefato não é seletivo, aprisionando indiscriminadamente machos, fềmeas $\mathrm{e}$ caranguejos jovens. Os catadores de caranguejo, em alguns manguezais, para marcar o caminho e a localização das armadilhas, cortam os galhos e cascas das árvores. Essa prática causa impacto não só sobre a fauna, mas também sobre a flora. 
Além do impacto ambiental, a facilidade de utilização dessa técnica possibilitou a captura do caranguejo por pessoas não pertencentes à comunidade tradicional e, portanto, não detentora de conhecimentos sobre o caranguejo e o ecossistema manguezal. $\mathrm{O}$ caranguejo passou a ser capturado indiscriminadamente, sem preocupação com sustentabilidade da atividade.

A legislação vigente proíbe a cata do caranguejo pro meio da utilização da "redinha". Mas não há fiscalização suficiente para coibir essa prática e, apesar da maioria dos catadores ter a informação sobre as conseqüencias causadas pelo seu uso, continuam a fazê-lo.

RUSCHI (1950), fez referência aos bosques de mangue e aos alimentos fornecidos por ele. ROSA (1957), em sua obra "História Econômica do Brasil", descreveu a super abundância de alimentos na Baía de Vitória e atividade de cata praticada pelos indígenas. MELLO (1966), na obra "Diálogos das Grandezas do Brasil", referiu-se aos recursos naturais do Brasil, mencionando as diferentes "castas" de caranguejos que eram sustento dos índios, dos escravos provenientes da Guiné e dos pobres. ALCÂNTARA (1978), elaborou uma tese em que tratou da biologia e ecologia do caranguejo-uçá. NASCIMENTO e colaboradores (1984), caracterizaram os manguezais do Estado do Sergipe, realizando inclusive, um estudo bio-ecológico do caranguejo-uçá. Todas essas pesquisas abordam diferentes aspectos da utilização do caranguejo-uçá (ucides cordatus) como fonte de alimentação.

O Brasil é considerado o país que tem a maior área de manguezal. São 25 mil quilômetros quadrados, distribuídos em 7.408 quilômetros de orla litorânea que vão do extremo norte do Amapá até São Francisco do Sul, em Santa Catarina. Em toda esta extensão, destacam-se na produção de caranguejos a região do Salgado, no Pará, o delta do Parnaíba, entre Maranhão e Piauí, todo o Estado de Sergipe, as baias de Guanabara e de Sepetiba, no Rio de Janeiro, e o manguezal de Iguape-Cananéia, na divisa entre São Paulo e Paraná. Destas, Sergipe é o maior produtor e o estado que mais estuda o caranguejo-uçá (espécie mais comercial). De seus manguezais saem 
por semana uma média de 100 mil crustáceos, que em grande parte vão ser vendidos nas feiras da Bahia.

Os manguezais têm o clima mais ameno da zona costeira por causa da vegetação e são considerados por biólogos, pescadores e catadores como verdadeiras fábricas de alimento. Ambientes altamente produtivos, os manguezais são elos básicos para cerca de dois terços das espécies de peixe, que dependem deles ou para a procriação ou para a alimentação. Nessa cadeia, os caranguejos têm uma importância fundamental.

Moradores permanentes desse ambiente inóspito e pouco oxigenado, são eles que criam condições de vida para a flora e fauna do mangue. Quando os caranguejos fazem suas tocas, eles revolvem o solo mais profundo, oxigenando e distribuindo nutrientes que depois serão fornecidos ao mar com as cheias e vazantes da maré. Toda uma cadeia alimentar depende da atividade destes crustáceos, e a extinção dos mangues e dos caranguejos significa distribuir este ciclo, onde a atividade da pesca será a primeira afetada.

Durante a andada para acasalamento e liberação das larvas, apesar da fiscalização e dos esclarecimentos prestados pelos órgãos governamentais, muitos catadores regulares e outras pessoas ribeirinhas ou desempregadas que normalmente não catam caranguejo, capturam os animais, dentre eles muitas fêmeas ovigeras e espécimes menores que o permitido.

Para minimizar esses problemas, o Instituto Brasileiro do Meio Ambiente e dos Recursos Naturais Renováveis (IBAMA) publicou, em 1998, a primeira portaria para a região Sudeste e Sul (portaria $n^{\circ} 104$, de 27 de julho de 1998) que implantou o "período do defeso" para o caranguejo e deu outras providências relativas ao tamanho minimo de captura e técnicas de coleta. Entretanto, a legislação vigente não proíbe a captura durante o periodo reprodutivo, pois estabeleceu um periodo de defeso que não inclui os meses em que ocorre a reprodução da espécie no Estado do 
Espírito Santo, não sendo eficaz, portanto, para proteger o caranguejo durante esse período.

Outros trabalhos relatam a fixação do homem nas áreas de manguezal em estágio lento, atraidos, sobretudo, pela alimentação fornecida pelos mesmos, sem os grandes impactos verificados hoje. Deste modo citam-se os trabalhos de ANDRADE (1974), que estudou a geografia econômica do nordeste e a coleta de crustáceos; DIEGUES (1990), que escreveu um trabalho sobre as comunidades litorâneas e os manguezais do Brasil; LUCENA (1991), que descreveu os catadores de caranguejos no povoado de Livramento (PB). Entre outros, dois trabalhos merecem especial destaque no que se refere à forte relação do homem e o manguezal como fonte de alimento.

O primeiro trabalho é o de CASTRO (1983), que ao defender as populações dos alagados do Recife (PE), narra com muita sensibilidade a estreita relação existente entre os homens que habitavam os manguezais e os caranguejos:

E, foi assim que, pelas histórias dos homens e pelo roteiro do rio. fiquei sabendo que a fome não era um produto exclusivo dos mangues. Que os mangues apenas atraiam os homens famintos do Nordeste inteiro: da zona da seca e os da zona da cana. Todos atraidos por este terra da promissão, vindo se aninhar naquele ninho de lama, construido pelos rios $e$ onde brota o maravilhoso ciclo do caranguejo (p.24).

O segundo trabalho é o de ANDRADE (1984), que em sua pesquisa na "Região do Salgado" (PA), coletou importantes dados sobre o "folclore do manguezal" e da utilização da sua fauna para alimentação das populações do local. Sobre isso escreveu:

O problema do sustento do homem não se resolve com quantidade, mas com a qualidade do alimento oferecido (...). Ora. o mangal oculta. num escaninho singular de vida, um celeiro pouco conhecido. (...) Ele esta a 
merecer pesquisa conjunta de cientistas para levantar sua potencialidade e, enquanto é tempo, evitar a predação (p.72).

Este trabalho, dentro da bibliografia consultada, foi o mais específico no tratamento exclusivo da alimentação fornecida pelo manguezal e do seu aproveitamento pelas comunidades litorâneas, no caso a região do Salgado (PA).

\section{A ETNOGRAFIA DOS CATADORES DE CARANGUEJOS}

Segundo ALVES (2004), os catadores de caranguejos são possuidores de um conhecimento altamente elaborado sobre a biologia do caranguejo, à influência das fases da lua e dos ventos nas marés e no manguezal. Para sobreviver da cata desse crustáceo, foi necessário desenvolver e transmitir, ao longo de gerações, um saber sobre a ecologia, o comportamento e a taxonomia dessa espécie.

CASTRO (1983), ao descrever as populações dos alagados do Recife, narrou com muita sensibilidade a estreita relação entre as comunidades que habitavam os manguezais e os caranguejos.

O catador de caranguejo tem conhecimento sobre as técnicas de locomoção no manguezal: pisar sempre próximo às raizes, manter o corpo inclinado para frente, andar por dentro d'água ou por cima das raízes nas bordas da floresta e tomar muito cuidado com as ostras, pois cortam feito navalha. Andar na lama cerca de quatro horas por dia e ainda carregar um saco com até dez dúzias de caranguejo exige, além de habilidade, muito preparo físico.

O início do expediente para os catadores de caranguejos é marcado pelo movimento das marés. A coleta diária dura cerca de seis horas, no entanto, alguns catadores acampam nas proximidades do manguezal por quatro ou cinco dias, capturando os caranguejos a cada período de maré baixa. 
Em todo o litoral brasileiro, as populações tradicionais de catadores vivem exclusivamente dessa atividade. São pessoas que dependem do meio ambiente para sua sobrevivência e, que por isso mesmo, eles interagem, respeitando seus ciclos naturais. De acordo com o saber popular, os catadores de caranguejos conhecem tão bem os caranguejos que sabem diferenciá-los por espécie, idade e sexo. Mas há os catadores esporádicos, predadores vindos de outras profissões, que se dedicam a capturar o caranguejo na "época da andada", quando se realiza o grande passeio para o acasalamento.

A invasão das regiões, onde moravam as comunidades catadoras de caranguejo e dos mangues próximos às suas casas teve início no município de Vitória em 1977, no bairro de São Pedro I, continuando até 1989, quando a Prefeitura Municipal de Vitória (PMV) desenvolveu um projeto de contenção das invasões e de preservação do manguezal. Os locais, onde antigamente os caranguejeiros tiravam seu sustento, o caranguejo, foram aterrados e transformados em bairros. As florestas de mangue foram substituídas por áreas residenciais (BONDUKI 1996).

LIMA (1984), estudou a Laguna do Mundaú (AL) destacando a relação das comunidades ali instaladas com o meio ambiente. A autora descreve como uma comunidade pesqueira/coletora vivenciou a problemática dos impactos ambientais, provocado pelo crescimento econômico.

A pressão de captura no manguezal de Vitória está tão intensa que os caranguejos estão sendo capturados e comercializados antes de chegarem ao tamanho considerado como ideal para o consumo. As comunidades que vivem exclusivamente da cata do caranguejo estão sendo afetadas em função desta sobrepesca, que provoca a queda na população de caranguejos (ALVES 2004).

LUCENA (1991), descreveu como vivem os catadores de caranguejos do povoado de Nossa Senhora do Livramento (PB). DIEGUES (1990), apresentou no II Simpósio de Ecossistemas da Costa Sul e Sudeste Brasileira, um trabalho muito interessante sobre as comunidades litorâneas e os manguezais do Brasil. KATER e 
KATER (1991), estudaram as condições de vida das "pescadeiras de crustáceos" e a degradação dos manguezais dos municípios de Igarassu e Itapissiuma (PE). Todas essas pesquisas ressaltam a importância que os catadores de caranguejo representam no contexto do ciclo de vida dos caranguejos e na caracterização do manguezal

NORDI (1992), fez a caracterização nutricional dos catadores de caranguejos, na região de Várzia Nova (PB), por meio da avaliação antropométrica. Efetuou medidas de peso, altura, circunstância braquial e dobra cutâneas. Concluiu que a cata do caranguejo-uçá está enquadrada como atividade de alto custo energético, principalmente, pela caminhada em sedimento lodoso e pelo transporte da mercadoria ao posto de comercialização. As atividades pós-coleta e os dias da semana que os catadores não freqüentaram o mangue foram considerados como estratégia de recuperação física e energética e de adaptação a ingesta calórica diária. As avaliações antropométricas dos catadores de caranguejo revelaram a existência de problemas nutricionais que podem ser interpretados como uma inadequação da ingesta a suas atividades diárias. Eles apresentaram um quadro de estabilidade nutricional ao longo do estudo, com poucas reservas adiposas. $\mathrm{O}$ consumo energético familiar foi deficiente, sendo que muitas famílias acusaram débitos calóricos agudos.

$\mathrm{Na}$ comunidade dos catadores de caranguejos do Município de Vitória, até o presente momento não foi realizado nenhum estudo referente à caracterização nutricional dos catadores.

A proteção ao meio ambiente é vital, porém, não é um fim em si mesma, assim como o crescimento econômico constitui apenas um meio, e não um fím (BARBIERI 1996). O objetivo dos nossos esforços deve ser proteger a vida e as opções humanas. Devemos optar por um desenvolvimento eqüitativo e sustentável, começando a ter um olhar mais crítico e a enxergar que, em muitos lugares, a espécie que está em maior perigo de extinção é a espécie humana, retratada aqui pelo catador de caranguejo. 
Nos últimos anos, a questão da preservação da diversidade cultural e biológica tem ganho ênfase (DIEGUES e col. 1998). Cresce o reconhecimento de que o modo de vida de alguns segmentos culturalmente diferenciados, é menos predatório do que o da sociedade industrial abrangente (CUNHA 1989).

GADGIL e colaboradores (1993), destacam a importância do conhecimento nativo ou tradicional para a conservação da biodiversidade, principalmente, de pescadores, de horticultores e de agricultores de subsistência. Segundo CLAY (1985), a chave do entendimento de atividades auto-sustentáveis em meios frágeis, começa com os residentes locais. Seu conhecimento é valioso para o futuro do ambiente e das pessoas e alerta para o fato, de que jamais aprenderemos sobre os sistemas de uso, se os povos que os desenvolveram continuarem a ser destruídos ou privados de continuar seus meios de vida.

No que concerne às relações que os pescadores artesanais mantêm com os ecossistemas litorâneos tem-se apontado o conhecimento e dependência que possuem do ambiente, o que permitiu a sustentabilidade no tempo dos recursos naturais e das relações sociais. O que os caracteriza, não é somente o viver da pesca, mas é sobretudo, a apropriação real dos meios de produção, o controle de como pescar e do que pescar (DIEGUES 1983).

As análises dos estudos sobre a pesca artesanal ressaltam aspectos como o conhecimento do mar, do tempo, das espécies e de seu comportamento; o controle de todo o processo de produção, a perecibilidade do produto o que determina a comercialização do mesmo, em condições desvantajosas definidas pelos intermediários, a divisão do trabalho, a ausência de vínculos empregatícios, os laços de afetividade, o fato de produzirem a sobrevivência num meio instável, o que torna a atividade perigosa. Todos esses fatores contribuíram para desenvolver a identidade cultural própria de pescador artesanal, como a valorização da independência, da autonomia, a desconfiança de pessoas de fora da comunidade, o conservadorismo, a resistência às mudanças e à incorporação de novas tecnologias (LAGO 1996). 


\section{A TEORIA DA EDUCAÇÃO AMBIENTAL E A SAÚDE PÚBLICA}

$\mathrm{Na}$ década de 60, a humanidade experimentou uma abrupta queda de qualidade de vida ocasionada pela rápida degradação ambiental. Em 1962, o mundo conhecia, por meio da linguagem simples da jornalista Rachel Carson em seu livro "Primavera Silenciosa", uma seqüência de desastres ambientais, em várias partes do mundo. Buscado em sucessivas edições por um público já alimentado por perdas de qualidade ambiental, o livro se tornaria um clássico dos movimentos preservacionista, ambientalista e ecologista em todo o mundo, e provocaria uma grande inquietação internacional sobre o tema. Tais inquietações chegaram à ONU seis anos depois, quando a delegação da Suécia chamou a atenção da comunidade internacional para a crescente crise do ambiente humano, sendo esta a primeira observação oficial sobre a necessidade de uma abordagem globalizante para a busca de soluções contra o agravamento dos problemas ambientais (DIAS 1991).

De acordo com NOVAES (2003), o ano de 1972 testemunhou os eventos mais decisivos para a evolução da abordagem ambiental no mundo. Impulsionada pela repercussão internacional do Relatório do Clube de Roma, a Organização das Nações Unidas promoveria, de 5 a 16 de junho, na Suécia, a "Conferência da ONU sobre o Ambiente Humano", ou Conferência de Estocolmo, como ficaria consagrada, reunindo representantes de 113 países, com o objetivo de estabelecer uma visão global e princípios comuns que servissem de inspiração e orientação à humanidade, para a preservação e melhoria do ambiente humano. Considerada um marco histórico-político internacional, decisivo para o surgimento de políticas de gerenciamento ambiental, a Conferência gerou a "Declaração sobre o Ambiente Humano", estabeleceu um "Plano de Ação Mundial" e, em particular, recomendou que deveria ser organizado um Programa Internacional de Educação Ambiental. A recomendação $\mathrm{n}^{\circ} 96$ da Declaração reconhecia o desenvolvimento da Educação Ambiental como o elemento fundamental para combate à crise ambiental. 
Segundo FELDMANN (2003), em resposta às recomendações da Conferência de Estocolmo, a Unesco promoveria em Belgrado, Iugoslávia (1975), o Encontro Internacional sobre Educação Ambiental, congregando especialistas de 65 paises. No encontro, foram formulados princípios e orientações para um programa internacional de Educação Ambiental, segundo os quais esta deveria ser contínua, multidisciplinar, integrada às diferenças regionais e voltada para interesses nacionais. Ficaria acertada a realização de uma conferência intergovernamental, dentro de dois anos, com o objetivo de estabelecer as bases conceituais e metodológicas para o desenvolvimento da Educação Ambiental, em nivel mundial. Outrossim, a discussão sobre as grandes disparidades entre os países do Norte e do Sul, à luz da crescente perda de qualidade de vida, gerou, nesse encontro, a Carta de Belgrado, em que se expressava a necessidade do exercício de uma nova ética global, que proporcionasse a erradicação da pobreza, da fome, do analfabetismo, da poluição e da dominação e da exploração humana. A Carta, um dos documentos considerados mais lúcidos produzidos sobre o tema na época, preconizava que os recursos do mundo deveriam ser utilizados de um modo que beneficiasse toda a humanidade e proporcionasse a todos a possibilidade de aumento da qualidade de vida .

Percebe-se essa situação e sabe-se da urgência ditada pela perda de qualidade ambiental, amplamente discutida na comunidade internacional em 1976, os órgãos estaduais brasileiros de meio ambiente tomaram a iniciativa de promover Educação Ambiental no Brasil. Começariam a surgir parcerias entre as instituições de meio ambiente e as Secretarias de Educação dos Estados. Ao mesmo tempo, dissemina-se no país o "ecologismo" - deformação de abordagem que circunscrevia a importância da Educação Ambiental à flora e à fauna, à apologia do "verde pelo verde", sem que as nossas mazelas socioeconômicas fossem consideradas neste tipo de análise, conforme proposta por instituições internacionais com sede nos países ricos. Por sua vez, o Ministério da Educação e do Desporto (MEC) e o Ministério do interior (MINTER), como para reafirmar sua inoperância, firmaram "Protocolos de Intenções", com o objetivo de formalizar trabalhos conjuntos, segundo DIAS (2000), visando à "inclusão de temas ecológicos" (sic) nos currículos do ensino de $1^{\circ}$ e $2^{\circ}$ graus. Tais "Protocolos de Intenções", "pérolas" refinadas da idiossincrasia 
tecnocrata vigente, nunca sairiam realmente das intenções e seriam prósperos em fazer a conexão entre o nada e coisa alguma (DIAS 2000).

Assim, realizar-se-ia de 14 a 26 de outubro de 1975, em Tbilisi, na Geórgia (ex-União Soviética), a Primeira Conferência Intergovernamental sobre Educação Ambiental, organizada pela UNESCO, em colaboração com o Programa das Nações Unidas para o Meio Ambiente (PNUMA). Foi um prolongamento da Conferência das Nações Unidas sobre o Ambiente Humano ocorrida em Estocolmo em 1972.

Segundo BESSERMAN (2003), a Conferência de Tbilisi - como ficou consagrada - foi o ponto culminante da Primeira Fase do Programa Internacional de Educação Ambiental (PIEA), iniciado em 1975, em Belgrado. Reuniu especialistas de todo o mundo, para apreciar e discutir propostas elaboradas em vários encontros sub-regionais, promovidas em todos os paises acreditados na ONU, e contribuiu para precisar a natureza da Educação Ambiental, definindo seus princípios, objetivos e características, formulando recomendações e estratégicas pertinentes aos planos regional, nacional e internacional. Lançou a Conferência, ainda, um chamamento aos estados membros, para que incluíssem, em suas políticas de educação, medidas que visassem à incorporação dos conteúdos, diretrizes e atividades ambientais nos seus sistemas e convidou as autoridades a intensificarem seus trabalhos de reflexão, pesquisa e inovação, com respeito à Educação Ambiental.

Para o desenvolvimento da Educação Ambiental, foi recomendado que se considerassem todos os aspectos que compõem a questão ambiental, ou seja, os aspectos políticos, sociais, econômicos, científicos, tecnológicos, culturais, ecológicos e éticos; que a Educação Ambiental deveria ser o resultado de uma reorientação e articulação de diversas disciplinas e experiências educativas, que facilitassem a visão integrada do ambiente; que os indivíduos e a coletividade pudessem compreender a natureza complexa do ambiente e adquirir os conhecimentos, os valores, os comportamentos $\mathrm{e}$ as habilidades práticas para participar eficazmente da prevenção e solução dos problemas ambientais; que se mostrassem, com toda clareza, as interdependências econômicas, políticas e 
ecológicas do mundo moderno, em que as decisões e comportamentos dos diversos paises produziriam conseqüências de alcance internacional que suscitassem uma vinculação mais estreita entre os processos educativos e a realidade, estruturando suas atividades em torno dos problemas concretos que se impõem à comunidade $\mathrm{e}$ enfocando-as por meio de uma perspectiva interdisciplinar e globalizadora; que fosse concebida como um processo contínuo, dirigido a todos os grupos de idade e categorias profissionais.

Sobre o assunto, REIGOTA (2002), afirma que o compromisso político de toda pessoa interessada em praticar a Educação Ambiental deverá estar relacionado com a possibilidade (utópica) de construção de uma sociedade sustentável baseada na justiça, dignidade, solidariedade, civilidade, ética e cidadania. Vai mais além e considera como condição básica para assumir esse compromisso, a competência técnica. Com a aquisição de conhecimentos específicos sobre a problemática ambiental, a ser considerada, assim como a compreensão das implicações sociais, culturais, econômicas e pessoais.

A Educação Ambiental é um processo de ensino-aprendizagem para o exercício da cidadania da responsabilidade social e política. É preciso agregar a teoria da educação aos aspectos que envolvem questões que atingem a sociedade, assim como, o saneamento, a saúde pública, a comunicação, os ecossistemas, a sociedade e escolher as melhores estratégias para a condução da população para o tema. Conclui afirmando que toda prática educativa envolve uma teoria que se baseia numa concepção de homem e de mundo (PHILIPPI e PELICIONI 2002).

Dessa forma, a Educação Ambiental estabelece um conjunto de elementos capaz de compor um processo por meio do qual o ser humano percebe, de forma nítida, reflexiva e crítica, os mecanismos sociais, políticos e econômicos que estavam estabelecendo uma nova dinâmica global, preparando-os para o exercício pleno, responsável e consciente dos seus direitos de cidadão, por meio dos diversos canais de participação comunitária, em busca da melhoria de sua qualidade de vida e, em última análise, da qualidade da experiência humana. 
No final de 1989, o MEC criou o Grupo de Trabalho para a Educação Ambiental, que seria coordenado pela professora Neli Aparecida de Melo. A partir daí, uma série de iniciativas teria lugar, principalmente, após a Conferência das Nações Unidas sobre o Desenvolvimento e o Meio Ambiente, realizada no Rio de Janeiro (Rio - 92), com a participação de representantes de 170 países.

De acordo com CRESPO (2003), a Rio - 92, em termos de Educação Ambiental, corroborou as premissas de Tbilisi e Moscou e acrescentou a necessidade de concentração de esforços para a erradicação do analfabetismo ambiental e para as atividades de capacitação de recursos humanos para área. Visando à concretização das recomendações aprovadas nessa conferência, o MEC instituiu um Grupo de Trabalho em caráter permanente (Portaria 773 de 10/05/93), para também coordenar, apoiar, acompanhar, avaliar e orientar as ações, metas e estratégias para a implantação da Educação Ambiental nos sistemas de ensino, em todos os niveis e modalidades. Esse Grupo de Trabalho conseguiu promover em todas as regiões do país encontros com as Secretarias de Educação dos Estados e Municípios para planejamento conjunto, mas foi prejudicado pela deficiência de informações sobre o assunto, da parte dos participantes, na maioria dos encontros promovidos. A despeito dessas dificuldades, o grupo conseguiu realizar, em dois anos, o que o MEC não fora capaz, desde a Conferência de Tbilisi, em 1977.

No Centro de Ecoalfabetização da Califórnia, CAPRA e colaborador (2003), estão desenvolvendo, nos níveis da escola primária e secundária, um sistema de educação para uma vida sustentável. Com uma pedagogia centrada na compreensão da vida, uma experiência de aprendizagem no mundo real que supere a alienação da natureza e reascenda o senso de participação com um curriculo que ensine as crianças os principios básicos da ecologia.

A Educação Ambiental, como parte do processo educacional, deve ser utilizada para diminuir as desigualdades de informação e de qualidade de vida, contribuindo para um contínuo exercício da cidadania e participação dos cidadãos. 
As estratégias para a educação ambiental como parte de um processo ambiental mais amplo devem considerar a observação, a experimentação, a síntese e o trabalho prático, como componentes importantes do problema.

A Educação Ambiental está diretamente correlacionada ao conceito de meio ambiente, patrimônio comum da humanidade e, para o seu entendimento, os aspectos ecológicos, econômicos, políticos, sociais e culturais devem ser considerados como constitutivos de um conhecimento integrado para a formação de uma visão holística.

REIGOTA (1991), definiu o meio ambiente como o lugar determinado ou percebido onde os elementos naturais e sociais estão em relações dinâmicas e em interação. Essas relações implicam processos de criação cultural e tecnológica e processos históricos e sociais de transformação do meio natural e construído.

Com o intenso processo de urbanização mundial que ocorre de maneira cada vez mais acelerada, as cidades passaram a ser o foco das atenções do mundo contemporâneo. Dentro de alguns poucos anos, mais da metade da população mundial viverá em cidades. Uma urbanização sem precedentes em nossa história, que com seus desdobramentos fisicos, sociais e econômicos, provoca um impacto importante na saúde da população. Hoje, com os grandes tormentos da poluição, da violência e da pobreza, as cidades deixaram de assegurar uma boa qualidade de vida e tornaram-se ambientes insalubres (GOUVEIA 1999).

A Organização Mundial da Saúde (OMS) define Saúde Ambiental como "as conseqüências na saúde da interação entre a população humana e o meio ambiente físico-natural e o transformado pelo homem e o social" (WHO 1996). Saúde Ambiental também pode ser entendida apenas como agravos à saúde devido a fatores físicos, químicos e biológicos mais diretamente relacionados com a poluição, o que atribui um caráter eminentemente ecológico ao processo saúde-doença.

A industrialização e os avanços tecnológicos fizeram aumentar consideravelmente a quantidade e a variedade de contaminantes químicos eliminados no meio ambiente, ao mesmo tempo em que o processo de urbanização mundial sem 
precedentes tem vastas implicações na qualidade de vida da população, objetivo comum à educação em saúde e à educação ambiental.

Desse modo, enquanto, de um lado, as concepções dominantes do processo saúde-doença se distanciavam cada vez mais do conceito de "meio ambiente", de outro lado, a degradação crescente deste meio, principalmente nas áreas urbanas, fez multiplicar os movimentos de caráter ambientalista, que passaram a ter um escopo mais abrangente, mas quase nunca tendo a saúde como prioridade. Apenas mais recentemente, com o agravamento da degradação ambiental e a observação de suas conseqüências diretas na saúde, é que essas duas áreas voltaram a convergir (GOUVEIA 1999).

Ao contrário do que se acreditava, a crise do meio ambiente urbano está apresentando um impacto na saúde, maior e mais imediato do que o esperado, de problemas ambientais considerados prioritários, como as mudanças climáticas globais, chuva ácida, destruição de florestas tropicais, e desaparecimento de diversas espécies animais e vegetais (ROSSI e col. 1991). Dentre os diversos problemas relacionados com a saúde ambiental podemos citar: a água e saneamento, moradia, resíduos sólidos (lixo) e poluição do ar. É necessário, portanto, que haja maior integração das questões do meio ambiente nas políticas de saúde de modo a garantir à população o direito à saúde e a um ambiente equilibrado e saudável na perspectiva do desenvolvimento sustentável.

A Constituição de 1988, estabelece que "a saúde é direito de todos e dever do Estado, garantida mediante políticas sociais e econômicas que visem à redução do risco de doenças e de outros agravos e ao acesso universal e igualitário às ações e serviços para sua promoção, proteção e recuperação" (art. 196). Determina, também, que todos têm direito ao meio ambiente ecologicamente equilibrado, bem de uso comum do povo e essencial à sadia qualidade de vida, impondo-se ao Poder Público e à coletividade o dever de defendê-lo e preservá-lo para as presentes e futuras gerações (art. 225) e incumbe ao Poder Público "promover a educação ambiental em 
todos os niveis de ensino e a conscientização pública para a preservação do meio ambiente (art. $225-\mathrm{VI})$ "'.

Embora a legislação preconize a promoção da saúde de forma integrada com a proteção ao meio ambiente, ainda continuam a ser considerados, na realidade, apesar das recomendações oficiais, como setores distintos. É preciso, portanto, reincorporar as questões do meio ambiente às políticas de saúde e integrar os objetivos da saúde ambiental numa ampla estratégia de desenvolvimento sustentável.

Para que isso ocorra, é preciso formar recursos humanos conscientes, com pensamento crítico, baseado em conceitos éticos, com postura participativa em suas comunidades, aptos, portanto, a enfrentar esse novo paradigma.

\section{O PROCESSO EDUCATIVO VISANDO AO DESENVOLVIMENTO DA SUSTENTABILIDADE}

Nos últimos anos começaram a emergir os problemas decorrentes da degradação ambiental relativa à utilização predatória do meio ambiente, acima de suas capacidades de regeneração. A natureza, tratada como mercadoria ou estoque infindável de recursos, sofreu danos irreparáveis diante da busca desenfreada por mais status social produzida pela ideologia capitalista, fundamentada na quantificação de bens materiais acumulados.

A globalização da economia e dos mercados, as mudanças constantes no ambiente externo às organizações e a necessidade de antecipar-se para manter a competitividade, aliados às fortes alterações no comportamento, atitudes e expectativas de consumidores, investidores e da classe trabalhadora como um todo, reflete de maneira direta a influência da reestruturação do modo capitalista de produção, por meio do qual se modelam novas formas organizacionais e condicionam-se as bases das mudanças sociais. 
Nesse novo contexto, a produção apresenta-se como um processo social novo e complexo, em que cada elemento é diferenciado internamente, e os recursos naturais assumem um papel determinante.

Os modelos produtivos configuram-se então, diretamente dependentes da natureza. A natureza modificada pelo homem, a natureza produzida pelo homem e a própria natureza humana, visto que a ação humana de milênios incorporou o meio ambiente natural na estrutura social, tornando o homem, "de forma concreta e simbólica, parte inseparável desse meio ambiente" (CASTELLS 1999).

Por meio da ideologia capitalista, os países pobres são estimulados a explorar seus recursos naturais e estes, fazem-no por necessidade de sobrevivência, impondo-se apenas o modo predatório como uma alternativa de desenvolvimento necessária para a superação das condições sócio-econômicas. Segundo o Relatório da Comissão Mundial de Meio Ambiente e Desenvolvimento (CMMAD 1991).

\begin{abstract}
Muitas partes do mundo entraram numa espiral descendente e viciosa: os povos mais pobres são obrigados a usar excessivamente seus recursos ambientais a fim de sobreviverem. e o fato de empobrecerem seu meio ambiente os empobrece mais, tornando sua sobrevivência mais dificil e incerta. A prosperidade conseguida em algumas partes do mundo é com freqüência precária, pois foi obtida mediante práticas agricolas, florestais e industriais que só trazem lucro e progresso em curto prazo.
\end{abstract}

Nessa ótica, o atual ritmo de consumo assinala para uma crise sem precedentes na história da humanidade num cenário de escassez de recursos e de um estado de degradação ambiental irreversíveis. As conseqüências desse estilo de desenvolvimento sobre o meio ambiente são inúmeras e quase irreversíveis. E como conseqüências sócio-econômicas pode-se citar o aumento do contingente de pobres e da desigualdade social, a diminuição do número de postos de trabalho, a perda do poder de compra de alguns seguimentos da classe média, entre outros. A educação, por sua vez, tornou-se mais instrumental para a sociedade e mais lucrativa como 
setor econômico, e o acesso à saúde cada vez mais diferenciado. Diante de tantas vulnerabilidades, exclusões e danos, torna-se urgente vislumbrar novas alternativas, pensar em novas formas de desenvolvimento que estejam relacionadas com a idéia de meio ambiente saudável, de justiça social e de cidadania com capacidade de reflexão e de trabalho (BARBIERI e LAGE 2001).

Até os anos 60, a questão ambiental, nas raras vezes que era tratada, era vista como um problema interno de cada país. Nos anos mais recentes, passou a ser considerada como um problema global, a partir de desastres ecológicos que não respeitavam limites geográficos ou sócio-econômicos, como por exemplo, poluídos como por exemplo rios que atravessam vários países e extensas áreas de oceanos. Esse pensamento tomou proporções planetárias quando, em 1971, o Clube de Roma, entidade que reunia cientistas de vários paises, publicou o livro "Limites de Crescimento", contendo os resultados dos estudos liderados pelo cientista Dennis Meadows, que apontava que a humanidade no século XXI iria se defrontar com graves problemas, se não mudasse os padrões de produção e consumo (BARBIERI e LAGE 2001).

Desde que o homem, enquanto ser social e em constante interação com a natureza, descobriu que a continuidade da vida no planeta Terra depende do modo como foi executada a apropriação dos recursos naturais, surgiu a necessidade de buscar-se um novo modelo de desenvolvimento; um modelo de desenvolvimento que não aceite o falso conceito de que crescimento econômico exige destruição da natureza e degradação ambiental; um desenvolvimento com utilização sustentada dos recursos naturais, incorporando em seu processo a noção de crescimento com eqüidade social e equilíbrio ecológico; um desenvolvimento que assuma compromissos tanto com a atual, como com as futuras gerações (MUNHOZ 1991).

No ano de 1983, a Primeira-ministra da Noruega, Gro Harlem Brundtland, foi nomeada pela ONU para presidir e constituir uma comissão independente para estudar as questões relacionadas com o desenvolvimento da humanidade. Essa comissão foi denominada de Comissão Mundial sobre o Meio Ambiente e 
Desenvolvimento (CMMAD). Os resultados dos estudos dessa comissão foram reunidos no relatório "Nosso Futuro Comum", onde constava pela primeira vez o termo "desenvolvimento sustentável", na tentativa de incorporar o conceito de sustentabilidade ao conceito de desenvolvimento. Desse modo, desenvolvimento sustentável foi conceituado como "aquele que responde às necessidades do presente sem comprometer a capacidade de gerações futuras em atender às suas próprias necessidades" (CMMAD 1991).

Segundo essa conceituação, desenvolvimento sustentável pressupõe que a exploração dos recursos naturais deva ser feita em condições tais que as futuras gerações possam utilizar esses recursos e beneficiar-se de um processo contínuo e equilibrado de desenvolvimento, em que a redução das desigualdades econômicas e sociais e a diminuição da pobreza sejam metas fundamentais. Além disso, a preservação e restauração dos ecossistemas naturais, a reciclagem de materiais e o deslocamento das prioridades de um crescimento quantitativo para um crescimento qualitativo têm um papel importante. $\mathrm{O}$ crescimento tecnológico deve, sem dúvida, levar em conta o componente ambiental. É necessário buscar, insistentemente o equilibrio entre esses dois aspectos: o crescimento quantitativo e o crescimento qualitativo.

A sobrevivência da sociedade produtiva depende, portanto, de sua capacidade de utilização racional e de conservação dos recursos naturais. Pressupõe a implementação de estruturas e de processos flexíveis com o objetivo de eliminar ou atenuar os impactos ambientais decorrentes da atividade produtiva. Esse esforço adaptativo gera nas organizações produtivas uma crescente demanda por informações ambientais, para o desenvolvimento de manobras estratégicas que lhes permitam adaptar sua estrutura e funcionamento interno às exigências legais e sociais de controle e preservação ambiental.

Apesar de aparentemente simples, esse conceito traz consigo todas as dificuldades inerentes ao confronto da perspectiva capitalista, centrada no mercado e no lucro, com a perspectiva da solidariedade e da responsabilidade para com as 
gerações futuras. Nesse sentido, um dos grandes desafios para implementar este conceito, diz respeito à definição de quais são as necessidades da atual geração e quais serão as necessidades das gerações futuras (BARBIERI e LAGE 2001).

Passados, então, 20 anos da Conferência de Estocolmo, reuniram-se no Rio de Janeiro, em 1992 líderes de 178 países, na Conferência das Nações Unidas sobre Meio Ambiente e Desenvolvimento (CNUMAD), para discutir novamente a questão ambiental global. Naquela oportunidade, foi firmado um compromisso mundial para implementação de ações visando alcançar um desenvolvimento em bases sustentáveis. Esse compromisso, denominado Agenda 21, constituiu-se num documento com 40 capítulos, contendo recomendações sobre as questões que impedem ou dificultam a promoção do desenvolvimento sustentável nas sociedades atuais, quer sejam ricas ou pobres (BARBIERI e LAGE 2001).

$O$ conceito de sustentabilidade tem raízes fincadas na Ecologia e está associado à capacidade de recomposição e regeneração dos ecossistemas. Entretanto, a questão do meio ambiente e do desenvolvimento constituem-se numa discussão cheia de conflitos e divergências entre as várias partes interessadas no tema. Para um grupo com orientação mais ecológica, as teorias da natureza e da sociedade são interdependentes e estão intrinsecamente relacionadas e, portanto, não podem ser consideradas em separado. Para uma outra vertente, com orientação econômica, a questão ambiental traz consigo um conflito permanente entre a lógica da natureza, com seus ecossistemas, e a lógica do mercado, com seus propósitos de lucro.

Nesse contexto, pensar em sociedade sustentável significa ampliar as preocupações para todas as dimensões do desenvolvimento. Deve-se começar por uma abordagem interdimensional do conceito de sustentabilidade, de modo a permitir as interações dos fenômenos do meio ambiente dentro de uma visão mais ampla dos problemas que as sociedades, principalmente, dos países periféricos convivem como a pobreza, a desigualdade social, a falta de trabalho, as concentrações urbanas e tantos outros problemas que estão intrinsecamente relacionados. Nesse sentido, pode-se dizer que o conceito de sustentabilidade aborda 
outras dimensões das atividades humanas além da ecológica, tais como a econômica, a social, a espacial, a cultural, a tecnológica e a política, apesar de se reconhecer as dificuldades na determinação do limite claro de sustentabilidade entre cada uma dessas dimensões, principalmente, ao serem consideradas as relações de interdependência às quais essas dimensões estão sujeitas e dentro do contexto de uma sociedade plural (BARBIERI e LAGE 2001).

De acordo com SOUZA (2003), o conceito de desenvolvimento sustentável apresenta falhas e limitações, em princípio, por não se apresentar como um modelo fechado. Podendo ser adequado aos diversos interesses, apresenta apenas princípios norteadores, dando margem a cada segmento ou grupo da sociedade de estabelecer ações a serem colocadas em prática de acordo com os seus interesses particulares.

Sob o aspecto ético, não é mais aceito que o desenvolvimento exponha o patrimônio natural a formas de exploração que aumentam as diferenças sócioeconômicas, esgotem os recursos naturais e poluam os espaços naturais e construídos, sem pensar nas gerações futuras, mas, ao contrário exige-se uma sociedade sustentável que atenda às necessidades sociais de toda a população, inclusive a dos excluídos com igualdade e justiça (PELICIONI 1998).

O desenvolvimento econômico e o bem-estar do ser humano dependem dos recursos da Terra. O desenvolvimento sustentável é simplesmente impossível se for permitido que a degradação ambiental continue. Os recursos da Terra são suficientes para atender às necessidades de todos os seres vivos do planeta se forem manejados de forma eficiente e sustentados. Tanto a opulência quanto à pobreza podem causar problemas ao meio ambiente. $\mathrm{O}$ desenvolvimento econômico e o cuidado com o meio ambiente são compatíveis, interdependentes e necessários. A alta produtividade, a tecnologia moderna e o desenvolvimento econômico podem e devem coexistir com um meio ambiente saudável (DIAS 2000). 
A busca de um modelo de desenvolvimento sustentável para o pais depende necessariamente do processo educativo. Nenhuma estratégia de desenvolvimento sustentável terá efeito se não for acompanhada por politicas, programas e projetos de formação, informação e conscientização da sociedade (MUNHOZ 1991).

Concluindo segundo ALMEIDA (2003), a humanidade está diante de uma encruzilhada. A opção pode ser primária e suicida ou sábia e sustentável. No primeiro caso, é a situação em que empresas e indivíduos aceitam que a sustentabilidade é importante, mas não a consideram condição sine qua non para fazerem suas escolhas políticas, econômicas e de vida.

A segunda opção é a mudança da ênfase no desempenho econômico para uma nova prioridade: o equilíbrio entre as dimensões econômica, ambiental e social e o exercício da responsabilidade compartilhada entre governo, empresas e sociedade civil organizada. 


\section{OBJETIVOS}

\subsection{Objetivo geral}

Pretende-se, com os resultados do presente estudo:

1) Contribuir para o processo de gestão ambiental e melhoria das condições de vida dos catadores de caranguejo.

2) Propor estratégias a serem utilizadas em atividades de educação ambiental e saúde no manguezal.

3) Oferecer subsidios ao Projeto Caranguejo: "Bioecologia do Caranguejo Ucides Cordatus e caracterização sócio-econômica e de saúde dos catadores de caranguejo no Espírito Santo", na implantação de medidas efetivas de gestão compartilhada para a região do Municipio de Vitória e a utilização sustentada de seus ecossistemas e recursos

\subsection{Objetivos específicos}

Identificar aspectos sócio-econômico-culturais e ecológicos dos catadores de caranguejo e de suas famílias;

> Identificar o envolvimento da população de catadores de caranguejo do Município de Vitória nesta atividade;

Avaliar os agravos à saúde dos catadores de caranguejo, decorrentes do esforço despendido na locomoção, captura e transporte dos caranguejos dentro do manguezal e também das condições insalubres do ambiente de trabalho;

> Levantar as conseqüências ambientais da captura do caranguejo e de atividades correlacionadas; 
Analisar a cata do caranguejo enquanto atividade de subsistência econômica para os catadores de caranguejo.

$>$ Contribuir para melhoria das condições de vida e ambientais do grupo estudado.

\section{LOCALIZAÇÃo E CARACTERIZAÇÃo DA ÁREA DE ESTUDO}

O Estado do Espírito Santo integra à Região Sudeste, mais precisamente na porção oriental do Brasil, tendo como área territorial estadual $46.184,1 \mathrm{Km}^{2}$. Limitase com: Bahia (Norte), Oceano Atlântico (Leste), Rio de Janeiro (Sul) e Minas Gerais (Oeste). Apresenta duas regiões naturais, o litoral com 400 quilômetros e o planalto. Dados do último Censo (2000), apontam uma população de aproximadamente 3.093 .171 habitantes, que estão distribuídos entre os 78 municípios existentes, sendo Vitória (capital) o mais populoso.

O Espírito Santo possui 3,09 milhões de habitantes e é a $7^{\mathrm{a}}$ economia mais competitiva do Brasil. Seu crescimento industrial tem sido líder no cenário brasileiro dos últimos 2 anos. É o $4^{\circ}$ estado brasileiro em "Índice de Desenvolvimento Humano", e sua capital, Vitória, é a $4^{\mathrm{a}}$ em qualidade de vida no país. O Estado apresenta clima tropical em $416 \mathrm{Km}$ de litoral, com lindas praias e clima temperado e frio da montanha.

O levantamento, ordenado por Vasco Fernandes Coutinho, das terras a ele doadas por Carta régia leva colonizadores a descobrir, em 13 de Junho de 1535, uma grande ilha que chamaram de Ilha de Santo Antônio. A colonização efetivou-se com a doação da ilha a Duarte Lemos, que passou a chamar de Ilha. Em 1551, adversidades enfrentadas pelos colonizadores levaram Coutinho a transferir a sede do governo e de sua residência para a Ilha. Em 8 de setembro de 1551, os índios foram expulsos definitivamente da ilha, vitória atribuída a Nossa Senhora, quando surge o nome: Nossa Senhora da Vitória, e depois simplesmente Vitória. 
Fundada em 8 de setembro de 1551, é a terceira capital mais antiga do Brasil. Com área de $105 \mathrm{Km}^{2}$ e população de 290 mil habitantes, possui mais de 80 bairros, muitos com menos de 30 anos de ocupação. Os bairros são interligados ao mundo globalizado via atividades de comércio exterior e desenvolvimento de tecnologia. Mantém regiões que guardam a tradição dos pescadores e a arte quatrocentona das panelas de barro. Vitória, uma ilha cercada de beleza e oportunidades de negócios.

A região metropolitana da Grande Vitória - RMGV, é composta pelos municípios de Vitória, Vila Velha, Cariacica, Serra, Viana e Guarapari Esses seis municipios abrigam quase metade da população do Espírito Santo, ou seja, $46 \%$ do total, $57 \%$ da população urbana do Espirito Santo (Figura 01).

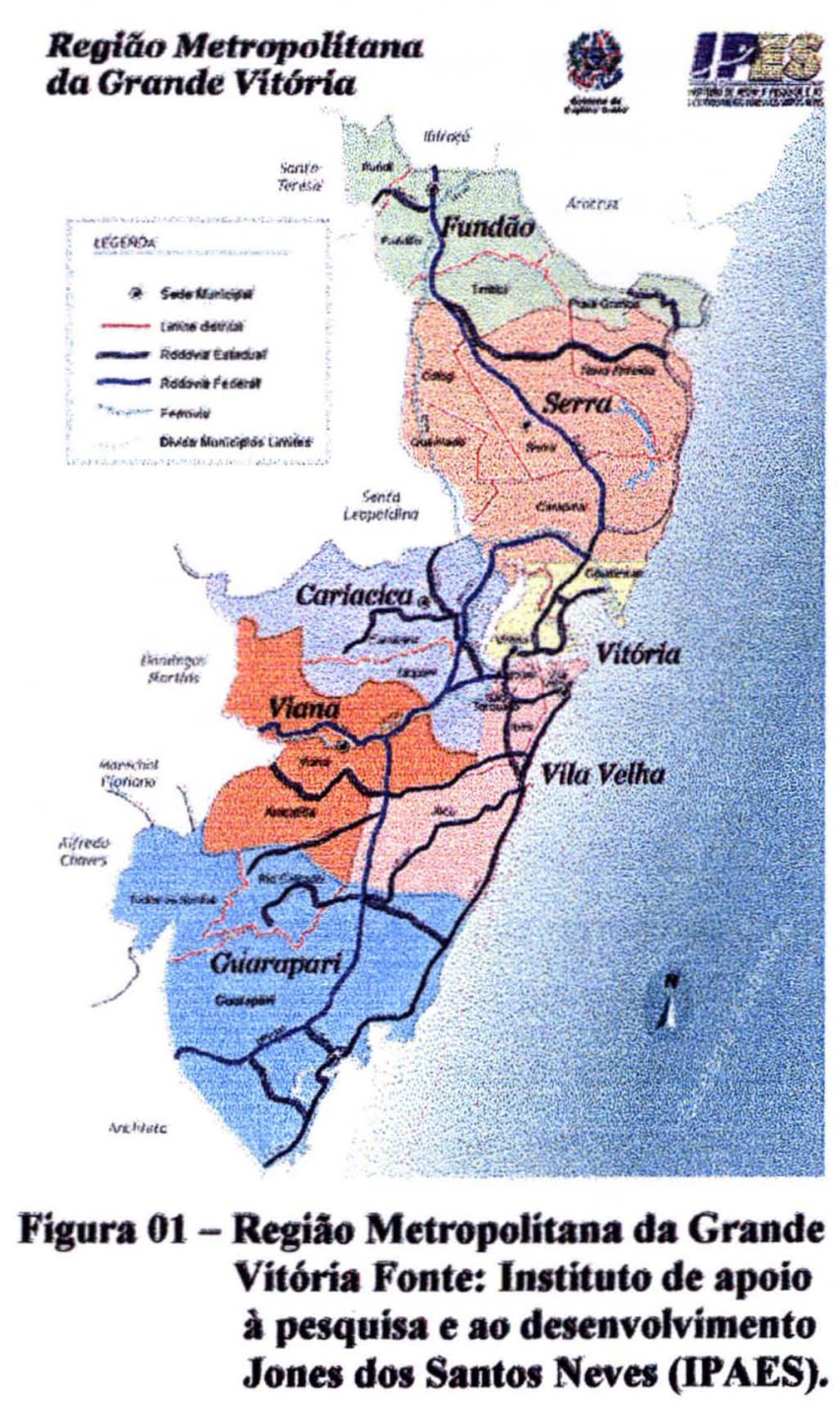




\section{METODOLOGIA}

\subsection{População de estudo}

Participaram da pesquisa 100 catadores de caranguejo, que atuam diretamente nessa atividade e que residem no município de Vitória (ES).

\subsection{Material e métodos}

Conforme SILVA (1988), se realmente se pretende sair da superficialidade do aparente, interessa captar as relações sociais que atravessam a comunidade, os problemas que a desafiam e a percepção que tem da realidade e de suas possibilidades de mudanças. Com base nesses pressupostos desenvolveu-se uma combinação de métodos quantitativos e qualitativos, acreditando-se na sua complementaridade e maior adequação à complexidade das relações humanas com o meio ambiente.

Dentre os métodos qualitativos, destaca-se o de observação direta, complementado por entrevistas semi - estruturadas. A técnica adotada é equivalente à do "observador participante não-membro", defendida por STEBBINS (1987), por garantir o distanciamento científico apropriado para a validação da pesquisa.

Baseado na sua experiência, o autor relacionou três pré-requisitos básicos para que o emprego desta técnica no trabalho de campo seja bem sucedido: primeiro, o pesquisador deve ter pelo menos uma compreensão mínima das atividades e do estilo de vida dos indivíduos com os quais fará o contato inicial. Ou seja, deve saber o suficiente das populações ou pessoas que desejam estudar; segundo, deve ser compreensivo com prováveis intolerâncias, ser paciente e ter discernimento quanto ao momento mais adequado para buscar informações, procurando intervir o mínimo possível, respeitar a posição do indivíduo e a dinâmica; e terceiro, o pesquisador precisa demonstrar entusiasmo e curiosidade sincera acerca do que os indivíduos têm a dizer, pois eles estão falando sobre o seu modo de vida, e continuarão a fazê-lo 
com desprendimento, se isto lhes parecer agradável e se é percebido que há interesse verdadeiro entre seus interlocutores.

Essas regras foram seguidas rigidamente nas abordagens, durante a pesquisa com os catadores de caranguejo. As visitas à comunidade dos catadores de caranguejos foram realizadas durante aproximadamente, seis meses, nos finais de semana. Durante as visitas, procurou-se adquirir a confiança da população, explicar as intenções da pesquisa, aprender a ouvir os catadores de caranguejo sobre suas dificuldades e recolher informações para o redirecionamento da pesquisa. As entrevistas contendo questões abertas e fechadas foram utilizadas com a finalidade de motivar o discurso do catador, de forma a possibilitar um melhor conhecimento de sua própria interpretação da realidade em que vive, permitindo a obtenção de dados com maior profundidade. Outra razão para a escolha da entrevista é o fato de um número significativo de pessoas possuir baixa escolaridade (GIL, 2000; MARCONI e LAKATOS, 1996; RICHARDSON, 1999).

Como refere MINAYO (1999), esse instrumento permite "compreender os valores culturais e as representações de determinado grupo sobre temas específicos" sendo capaz de "incorporar a questão do significado e da intencionalidade como inerentes aos atos, às estruturas sociais, como construções humanas significativas" (p.10).

Por sua vez, decidiu-se utilizar ainda a entrevista semi-estruturada, por ser um instrumento privilegiado de coleta de informações, pois a fala é reveladora de condições estruturais, de um sistema de valores, normas e símbolos, além de transmitir, através de um porta-voz, as representações de grupos sociais em situações sócio-econômicas, históricas e culturais específicas (MINAYO 1999).

\section{Instrumentos}

Para a coleta dos dados foram utilizados ainda os seguintes instrumentos:

- Mapas, para facilitar o roteiro, direcionados para as entrevistas individuais. 
- Anotações do diário de campo, com observações do grupo sistematizadas em mapas.

- Ficha para anamnese (anexo 2): foi utilizada para o levantamento e fichamento dos dados sobre a saúde dos catadores de caranguejo.

- Entrevistas espontâneas (anexo 4).

- Observação não participante, que possibilitou o registro do cotidiano dos catadores.

\section{Procedimentos}

O agendamento das entrevistas foi feito por ocasião do primeiro contato para reconhecimento da população alvo da pesquisa. Os registros foram anotados pelos entrevistadores em formulário próprio (anexo 1).

As entrevistas foram realizadas nas residências dos catadores, no período de junho a dezembro de 2003, pela pesquisadora, com a colaboração de oito alunos dos cursos de graduação da Faculdade de Saúde e Meio ambiente - FAESA, previamente treinados para esse fim, primeiro individualmente e, posteriormente, em grupo e supervisionados para garantir maior uniformidade na coleta de dados. Os registros das respostas foram feitos manualmente. A coleta foi realizada, às segundas-feiras, nos períodos da manhã e da tarde, respeitando os horários propostos pelos catadores de caranguejos. Todos os catadores de caranguejo concordaram em participar da pesquisa, depois de explicados seus objetivos.

Os dados sócio-econômico-culturais e ecológicos foram levantados a partir da aplicação de entrevistas semi-estruturadas com os 100 catadores de caranguejos. As questões foram as usuais nesse tipo de estudo, e se referiram ao nível de renda, escolaridade, composição familiar, condições ambientais e de moradia.

O registro das manifestações dos catadores de caranguejos, aspectos físicos, bem como as reflexões da pesquisadora surgidas em face da observação dos 
fenômenos foram realizadas com a utilização da observação direta (observador participante não-membro). Os registros foram anotados no diário de campo.

Do total dos catadores de caranguejo que participaram da pesquisa, somente $40(40 \%)$ compareceram para a realização da anamnese, levantamento e fichamento dos dados sobre a saúde realizada na Clínica-Escola Integrada da FAESA - Campus II, localizada no Bairro Condusa, Município de Vitória, nas proximidades dos bairros onde residia a maioria da população do estudo embora todos tivessem sido convidados.

O baixo número de participantes talvez possa ser explicado pela resistência dessa população em participar de alguns projetos. Esta conduta ficou bem clara na fala dos catadores, quando narravam a participação do grupo em projetos juntos à Prefeitura Municipal de Vitória. No entender dos mesmos, os técnicos não costumam dar retorno dos resultados de pesquisas realizadas na região, tendo ficado evidente o sentimento de que as pessoas haviam sido usadas como meio de obter informações pela Prefeitura Municipal de Vitória. Trata-se de uma problemática bastante complexa e de dificil solução, pois envolve aspectos sócio-culturais, políticos, educacionais, entre outros.

Outra provável explicação seria a falta de hábito de buscar atendimento preventivo e de promoção da saúde por razões de ordem cultural e de falta de acesso aos Serviços, mesmo quando a busca é para serviços curativos, tratamento e recuperação de doenças.

A informação é importante para a sensibilização da comunidade, mas a pedagogia exclusivamente informativa não motiva o participante a buscar soluções para os problemas da sociedade que, de alguma forma o atingem. $O$ material pedagógico elaborado para esse fim, algumas vezes, não reflete a realidade ambiental da localidade, onde ele é veiculado, ao invés de se inspirar na diversidade dos problemas locais, para envolver o interesse do usuário, o seu conteúdo é generalizado e conveniente ao ensejo do poder público. 
Foram duas as tentativas para a realização da anamnese, sendo que na primeira, compareceram seis catadores, enquanto que, na segunda, compareceram onze catadores

A primeira tentativa foi realizada no dia 01 de dezembro de 2003 , às 13 horas, em uma segunda-feira, dia da semana em que a maioria dos catadores não trabalha no mangue.

O convite foi realizado pela pesquisadora ao término de uma atividade promovida pela Prefeitura Municipal de Vitória em que todos os catadores estavam participando. Foi esclarecida ao grupo a relevância da participação de todos para que um dos objetivos previstos pelo projeto fosse alcançado e os resultados fossem aplicados em beneficio do grupo. A data para realização da anamnese foi marcada com uma semana de antecedência.

A segunda tentativa ocorreu na semana seguinte, no dia 08 de dezembro, no mesmo horário e levou-se em consideração o mesmo pressuposto anterior. $O$ atendimento foi solicitado por elementos do grupo que, por motivos diversos, não pôde comparecer na semana anterior. Foi aguardado pela equipe multidisciplinar, composta por professores e alunos, porém, os catadores não compareceram na hora prevista. A equipe aguardou por mais algum tempo, entretanto, como nenhum dos catadores agendados compareceu, a pesquisadora dirigiu-se à residência de alguns catadores na tentativa de encontrá-los. Do Bairro Inhanguetá, foram encaminhados 3 catadores, os demais relataram saber da importância do compromisso, mas alegaram que o cansaço não permitiu que comparecessem. Da Ilha das Caieiras, foram encaminhados 4 catadores, embora um número bem maior de catadores tivesse sido encontrado. A maioria dos catadores estava alcoolizada e os outros, em número de quatro, moradores do Bairro Jabour, utilizaram transporte cedido pela Prefeitura Municipal de Vitória e justificaram o atraso, pois estavam aguardando outros colegas, que não compareceram. 
$\mathrm{O}$ atendimento dos outros vinte e três catadores foi realizado em outros dias de acordo com a disponibilidade de cada um deles.

\subsection{Pré-teste}

Com a finalidade de verificar a adequação da linguagem, compreensão das questões e também se os objetivos propostos pelo estudo haviam sido contemplados por meio das questões, aplicou-se, como pré-teste, o formulário em população semelhante. O pré-teste realizou-se no bairro Cajueiro, município de Cariacica, ES, com a participação de 5 catadores de caranguejos, população com características semelhantes, portanto as dos catadores de Vitória. O roteiro de entrevista foi aplicado pela pesquisadora, nas residências dos catadores e mostrou-se pertinente para atender aos objetivos propostos pelo projeto.

\subsection{Aspectos Éticos da Pesquisa}

Os procedimentos metodológicos deste trabalho cumpriram as exigências éticas fundamentais, conforme a Resolução $\mathrm{n}^{\circ}$ 01, de 13/06/1988 - CNS, sobre pesquisas científicas desenvolvidas em seres humanos: a ausência de discriminação ou estigmatização dos agentes sociais envolvidos na pesquisa; o consentimento livre, esclarecido e por escrito para sua participação, assim como a garantia de privacidade e anonimato; a confidencialidade dos dados coletados e a publicação dos resultados da pesquisa como um todo (Anexo 3). 


\section{APRESENTAÇÃO E DISCUSSÃO DOS RESULTADOS}

\subsection{Descrição da população do estudo}

Entre os manguezais da Grande Vitória (ES), foram selecionados para esta pesquisa os mangues do município de Vitória, que se situam na região da Grande São Pedro, onde residem as comunidades atendidas pela Faculdade de Saúde e Meio Ambiente - FAESA (Campus II), que presta serviços de saúde e educação a essas comunidades.

Considerou-se a divisão do Município de Vitória segundo dados da Prefeitura Municipal de Vitória, para a apresentação da localização da população de estudo.

Para a descrição e discussão dos resultados, optou-se pela utilização dos dados quantitativos obtidos por meio da entrevista, e também os dados levantados a partir das observações registradas no diário de pesquisa de campo e na anamnese feita com os catadores de caranguejo por ocasião dos exames físicos.

Com a finalidade de identificar os aspectos sócio-econômico-culturais e ecológicos da população do estudo, que retratam em grande parte a sua qualidade de vida, foram estudadas as seguintes variáveis: localização do grupo de estudo por bairros, tempo de residência, idade, estado civil, condições de trabalho das esposas/companheiras, instrução dos entrevistados, número de filhos, tipo e condições de moradia, nível salarial e tipo de organização social.

Um total de 100 catadores de caranguejos, participou do estudo. Este número, no entanto, não corresponde necessariamente ao universo de catadores do municipio de Vitória. O cadastro existente na Prefeitura Municipal de Vitória não condiz com a realidade atual de catadores, pois alguns já não estão mais em atividade, ao mesmo tempo, outros indivíduos passaram a fazer parte do grupo. 


\section{Localização da população de estudo}

De acordo com COSTA (1981), a população de Vitória saltou de 45.212 habitantes em 1940, para 207.560 habitantes em 1980. Os fracassos verificados nas atividades agrícolas do país e o desenvolvimento industrial, principalmente nas décadas de 1960 e 1970, foram os responsáveis pela migração das populações rurais em direção aos centros urbanos, provocando a ocupação desordenada do espaço, sobretudo, das áreas de manguezais.

A descaracterização do manguezal como fonte de alimento imprescindível às populações litorâneas, transformou-o em área de fixação de palafitas, depósito de lixo e posterior sustentação de aterros, em prejuízo das populações tradicionais.

Em Vitória (ES), esse processo foi relatado por ANDREATTA (1987), em um livro sobre a ocupação do manguezal em um determinado local que, mais tarde, deu origem ao bairro São Pedro. Segundo seu depoimento, como participante da invasão, para aquela população só restou o manguezal como opção de moradia. Ao descrever a invasão dos terrenos de mangue ao longo da Rodovia Serafim Derenzi, em 1977, (atuais bairros de São Pedro I, II, III e IV, Redenção, Nova Palestina, Resistência, Conquista, Santo André e Joana D'arc) a autora documentou a fartura de caranguejo existente na área e o seu posterior aniquilamento, com o depósito de lixo, construção de palafitas e aterros. Sobre o assunto escreveu ANDREATTA:

(...) não poderemos renovar, jamais, a quantidade de caranguejos, siris $e$ outros peixes que destruimos. Temos plena consciencia de toda atrocidade contra a natureza (...) entre nós e os caranguejos, escolhemos nós, e ficamos com o mangue (...). Sabemos também que. enquanto temos que desalojar plantas e animais marinhos de seu habitat natural, nossos irmãos mais abastados moram em terra seca e têm quintal para seus filhos brincarem. ou clubes particulares (p. 133).

Vale ressaltar que essa população não pode ser considerada como “Civilização do Mangue”. Segundo DIEGUES (1987), seria necessário haver 
harmonia entre a população e o ambiente $O$ qụe se pôde observar é que, na situação analisada, essa harmonia foi totalmente destruída. Esses invasores, apesar de conscientes da destruição que causaram, não conseguem estabelecer uma forma de relação harmônica com os manguezais, como costuma acontecer em algumas comunidades indigenas e mesmo de pescadores.

No município de Vitória, em 2003, por ocasião da pesquisa, os catadores de caranguejos residiam nos seguintes bairros conforme apresentado na tabela 1 , a seguir.

Tabela 1 - Distribuição do número e da percentagem dos catadores de caranguejos do município de Vitória por bairro.

\begin{tabular}{lcc}
\hline Bairro & N & $\%$ \\
\hline Estrelinha & 16 & 16 \\
Jabour & 15 & 15 \\
Maria Ortiz & 15 & 15 \\
Inhanguetá & 14 & 14 \\
Ilha das Caieiras & 12 & 12 \\
São Pedro II & 8 & 8 \\
São Pedro I & 6 & 6 \\
Resistência & 4 & 4 \\
São Pedro III & 2 & 2 \\
Nova Palestina & 2 & 2 \\
São Pedro V & 2 & 2 \\
Grande Vitória & 2 & 2 \\
Redenção & 2 & 2 \\
\hline Total & 100 & 100 \\
\hline
\end{tabular}

Quanto ao local de residência, a tabela 1 mostra que $16 \%$ dos entrevistados residiam no bairro Estrelinha; $15 \%$ no bairro Jabour e Maria Ortiz; $14 \%$ em Inhanguetá; $12 \%$ no bairro Ilha das Caieiras; $8 \%$ no bairro São Pedro II; $6 \%$ no bairro São Pedro I; 4\% no bairro Resistência e 2\% nos demais. 
No decorrer da pesquisa, constatou-se que houve migração dos catadores residentes nos bairros Jabour e Maria Ortiz para a região do município da Serra, mais precisamente para os bairros Jardim Tropical e Jardim Carapina, motivados pelo alto custo do aluguel residencial. Mesmo residindo em outro Município, os catadores de caranguejo continuaram a pertencer ao mesmo grupo de trabalho, inclusive com relação ao rodízio do ponto de comercialização no bairro de Goiabeiras.

A destruição dos manguezais ao longo da Rodovia Serafim Derenzi acarretou conseqüências danosas aos moradores nativos da Ilha das Caieiras, pequena ilha de pescadores. Surgiu no final do século XIX, como ponto de descanso de remadores que desciam da região serrana pelo Rio Santa Maria trazendo produtos agrícolas. Os primeiros moradores eram colonos de fazendas de café e mercadores desejosos de mudar de vida, passando a dedicar-se à exploração do abundante pescado existente no estuário (DIAS 2001).

Atualmente, a maioria dos catadores de caranguejos nativos da Ilha das Caieiras se queixa da pouca quantidade e baixa qualidade dos caranguejos dessa baía. No passado, a atividade de cata era feita no local de moradia. Hoje, dada a escassez do crustáceo nas proximidades das residências, a cata foi transferida para a Estação Ecológica Municipal do Lameirão, uma grande ilha de manguezal e nos seus entornos e no delta do Rio Santa Maria, formado por suas ilhas de manguezal, sendo necessário para o deslocamento em torno de uma hora de viajem de barco.

\section{Faixa etária}

Conforme pode-se verificar na tabela 2 , a idade do grupo de estudo variou de 19 a 56 anos com freqüência maior na faixa etária de 28 a 38 anos (38\%).

Os que se encontravam na faixa que vai de 48 a 58 anos representavam apenas $10 \%$ do grupo entrevistado. Acima de 58 anos não foi encontrado nenhum catador praticando a cata do caranguejo. 
Tabela 2 - Distribuição do número e da percentagem dos catadores de caranguejos segundo a faixa etária.

\begin{tabular}{lcc}
\hline Faixa Etária & $\mathrm{N}$ & $\%$ \\
\hline $18 \vdash 28$ & 16 & 16 \\
$28 \vdash 38$ & 38 & 38 \\
$38 \vdash 48$ & 36 & 36 \\
$48 \vdash 58$ & 10 & 10 \\
\hline Total & 100 & 100 \\
\hline
\end{tabular}

Segundo a fala dos catadores de caranguejos, o oficio de catar caranguejo não está mais sendo passado de pai para filho, pois não acreditam que a família poderia continuar obtendo sua subsistência do mangue.

Observou-se que os mais jovens, menores de 18 anos, não estão seguindo o oficio dos pais, mas, encontravam-se estudando. Parte deles porque os pais já não se dedicam integralmente à sua atividade tradicional (a cata do caranguejo) e os demais, porque não encontram na família o incentivo, pois não consideram mais a cata do caranguejo uma boa opção de vida para o futuro de seus filhos.

GARCIA (1999), em estudo desenvolvido na comunidade de pescadores artesanais do entorno da Lagoa da Conceição (Florianópolis/ SC), encontrou-se em situação semelhante os pescadores que ainda se dedicavam à pesca, como principal atividade de sobrevivência, eram os mais velhos. Dos grupos pesquisados, $26 \%$ afirmaram que não conheciam outra opção para proporcionar o sustento da família. A população economicamente ativa entre esses pescadores, outrora, incluía as crianças a partir de 10 anos. Hoje, isto não mais ocorre, uma vez que os filhos de pescadores já não tendem a se manter na pesca como atividade principal.

A análise das faixas etárias entre o grupo de catadores de caranguejos, permitiu revelar caracteristicas interessantes quanto ao grau de necessidades que este grupo apresentou e buscava satisfazer, explorando os recursos disponiveis no 
ambiente. Verificou-se, também, uma provável redução de catadores mais jovens, quando comparado a outros estudos.

\section{Estado civil}

O estado civil dos catadores de caranguejo está representado na tabela 3 :

Tabela 3 - Número e percentagem dos catadores de caranguejos segundo o estado civil.

\begin{tabular}{lrr}
\hline Estado Civil & N & $\%$ \\
\hline Solteiro & 58 & 58 \\
Casado (de fato e de direito) & 34 & 34 \\
Separado & 6 & 6 \\
Viúvo & 2 & 2 \\
\hline Total & 100 & 100 \\
\hline
\end{tabular}

A tabela 3 permite observar que 58\% dos entrevistados declararam-se solteiros. Os 42 restantes distribuem-se entre casados (34\%), separados (6\%) e viúvos $(2 \%)$ no entanto grande parte mantinha relacionamento mesmo informal.

Conforme relato dos catadores, observou-se grande parte dos que se diziam solteiro, mantinham relacionamento informal.

\section{Condições de trabalho das esposas/ companheiras}

$\mathrm{Na}$ época da pesquisa, $26 \%$ das esposas/companheiras estavam trabalhando. Entre as $36 \%$ que não trabalhavam, 20 informaram que cuidavam da casa, 10 que não encontravam emprego e 5 eram aposentadas. Trinta e oito (38\%) não responderam a essa questão (Tabela 4 ). 
Tabela 4 - Situação das esposas/companheiras em relação a trabalho.

\begin{tabular}{lcc}
\hline Condições de Trabalho & $\mathrm{N}$ & $\%$ \\
\hline Trabalhavam & 26 & 26 \\
Não trabalhavam & 36 & 36 \\
NR & 38 & 38 \\
\hline Total & 100 & 100 \\
\hline
\end{tabular}

MACHADO (1995), relatou que para a comunidade de Zacarias, em Maricá/RJ, a pesca era um espaço masculino e reconhecido, genericamente, como "trabalho", conferindo aos praticantes, o status de "pescador". Na casa, estava o espaço da mulher, que "ajudava", mas "não trabalhava".

LAGO (1996), ressaltou que a atividade de pesca é tipicamente masculina. A mulher era considerada apenas como uma ajudante. $O$ trabalho acessório da mulher era o artesanato da renda.

De acordo com CASCAES (1978), à medida que a pesca assumia uma maior importância na economia das populações do litoral, foi se estabelecendo de forma mais marcada a divisão sexual do trabalho. Sexual por ser a pesca uma atividade tradicionalmente masculina.

$\mathrm{Na}$ Ilha de Búzios/SP, os homens eram os responsáveis pelo desenvolvimento da principal atividade econômica local, a pesca, além de desenvolverem também algumas atividades agrícolas. Apenas a participação masculina era contabilizada como renda na comunidade, uma vez que poucas mulheres tinham fontes de renda (BEGOSSI 1996).

No que se refere à participação nas atividades relacionadas à pesca, a exclusividade masculina é observada na maioria das comunidades de pescadores artesanais, também se confirma no município de Vitória como tendência. 
Entre os catadores de caranguejos, o mais comum era que os homens operassem, diretamente na atividade, ficando as mulheres restritas ao trabalho doméstico que envolve a educação dos filhos. Um pequeno contingente dessas esposas/companheiras colaboravam no orçamento doméstico, atuando em outras atividades: $20 \%$ como doméstica, $2 \%$ faxineira, $2 \%$ como atendente em cantinas escolares e $2 \%$ ficava com a venda do caranguejo e como desfiadeiras de crustáceos e mariscos.

“...Não, as mulheres que não trabalham no mangue, trabalham como domésticas para ajudar, pô..." (Jorge, 40 anos).

“...É muito bruto, é frio, arriscado pegar uma pneumonia, cobra, marimbondo dentro do mangue, porque no mangue tem de tudo rapaz, marimbondo, abelha, surucucu, às vezes você passa em cada rodizio de surucucu que a galha chega está arriada rapaz, não é assim não, o mangue não é fácil não, tem maruí, mutuca, mosquito pernilongo, tem isso tudo rapaz para enfrentar, entendeu?..." (Marcos, 23 anos).

“...Não tem necessidade não, elas não agüentam. Agente que se acidenta lá, como eu te falei, é cobra, maruí, pernilongo, abelha, surucucu e o que mais da no mangue, jibóia agente nem tem medo de jibóia, porque passa fora deixa ela para lá, nem mechemo com ela, ela num meche com você. Cabou, a surucucu é muito perigosa..." (Sergio, 42 anos)

\section{Filhos}

Houve interesse, no presente estudo, em levantar os dados a respeito do número de filhos dos entrevistados, pois considerou-se ser esta uma variável importante para esclarecer alguns comportamentos e mudanças na vida da população estudada. Verificou-se que 90 dos entrevistados tinham filhos, sendo 104 do sexo feminino e 98 do sexo masculino. Apenas 10 entrevistados (10\%) não tiveram filhos A maioria das familias era composta por mais de quatro filhos. 


\section{Nível de Instrução dos entrevistados}

Quanto ao grau de escolaridade, a maioria, (90\%) dos catadores entrevistados, freqüentaram a escola. Apenas 10\% declararam nunca ter freqüentado a escola.

A tabela 5 , mostra que somente $16 \%$ freqüentaram até o $1^{\circ}$ grau completo, demonstrando a baixa escolaridade dos catadores de caranguejo. É elevada, a porcentagem de catadores com o $1^{\circ}$ grau incompleto $(62 \%)$ e bastante significativo do ponto de vista qualitativo, os $10 \%$ de catadores sem nenhuma escolaridade. É importante observar que mesmo os catadores que declararam ter feito o $2^{\circ}$ grau completo, não tiveram condições suficientes para inserção no mercado de trabalho remunerado.

\begin{tabular}{lccc} 
Tabela 5 - Distribuição do número e percentagem dos & dos \\
$\begin{array}{c}\text { catadores de } \\
\text { escolaridade. }\end{array}$ & caranguejos & segundo & a \\
\hline Escolaridade & $\mathrm{N}$ & $\%$ \\
\hline Não alfabetizado & 10 & 10 \\
$1^{\circ}$ grau completo & 16 & 16 \\
$1^{\circ}$ grau incompleto & 62 & 62 \\
$2^{\circ}$ grau completo & 4 & 4 \\
$2^{\circ}$ grau incompleto & 8 & 8 \\
\hline Total & 100 & 100 \\
\hline
\end{tabular}

A educação é um direito social, assegurado na Constituição Federal "A educação, direito de todos e dever do Estado e da família, será promovida e incentivada com a colaboração da sociedade, visando ao pleno desenvolvimento da pessoa, seu preparo para o exercício da cidadania e sua qualificação para o trabalho" (art. 205). “O ensino público deverá ser gratuito em estabelecimentos oficiais" (art. 206 - IV) - (Brasil 1988).

A Constituição Federal prevê ainda que a educação deverá ser efetivada mediante a garantia: de ensino fundamental, obrigatório e gratuito, inclusive para os 
que a ele não tiveram acesso na idade própria; deverá ser progressivamente estendida a obrigatoriedade e gratuidade ao ensino médio; deverá ser oferecido atendimento educacional especializado aos portadores de deficiência, preferencialmente na rede regular de ensino; deverão ser atendidas em creche, e pré-escola, às crianças de zero a seis anos de idade; deverá ser garantido o acesso aos níveis mais elevados do ensino, da pesquisa e da criação artística, segundo a capacidade de cada um; deverá, também, ser oferecido o ensino noturno regular, adequado às condições do educando; deverá ser garantido atendimento ao educando, no ensino fundamental, por meio de programas suplementares de material didático-escolar, transporte, alimentação e assistência à saúde (art. 208).

A legislação, embora preconize a educação como um direito de todos, necessita de mais controle na qualidade do ensino e gestão eficazes de modo a garantir realmente aos cidadãos o direito a educação e seu desenvolvimento para o exercício da cidadania e qualificação para o trabalho. Os dados levantados demonstraram o baixo nível de instrução da categoria, $62 \%$ deles não completaram o $1^{\circ}$ grau, este fato talvez possa ser explicado pela dificuldade, em muitos casos, de conciliar estudo e trabalho.

O grau de instrução exibido por um dado segmento social, via de regra, está relacionado à condição de vida que seus integrantes possuem, muito embora não reflita, necessariamente, uma correspondente sensibilidade quando são tratadas as questões ambientais, nem tão pouco traduz, nos tempos atuais, a garantia de emprego.

Segundo SUNKEL (1998) citado por VIEIRA e colaboradores (1998), fazer da educação o objetivo central do desenvolvimento seria correto, mas pensar que o problema do desemprego resolveria se pudesse dispor de mais educação, não. $O$ autor declarou ser essa idéia falsa e comenta conhecer paises, onde existem muitos desempregados que aprenderam na escola, que trabalhar na terra não constituia opção legítima para "gente educada". 
Na verdade, a labuta no mar exige muito mais habilidade na "lida", adquirida por meio da experiência, como uma decorrência da prática, do que conhecimentos absorvidos nos bancos escolares.

Os dados obtidos, de certa forma corroboraram este raciocínio, muito embora, a maioria dos pescadores expressou o desejo de ver seus filhos dentro das escolas. Isto, não porque pensassem que lá receberiam ensinamentos fundamentais para continuarem operando como pescadores. Ao contrário, a maioria desejaria ver seus filhos dedicados a outras profissões que consideram mais promissoras economicamente falando e mais seguras.

Esse fenômeno pode ter caracterizado uma incapacidade por parte dos catadores em continuar a manter, apenas com a cata do caranguejo suas famílias, existindo a necessidade dos demais, buscarem renda complementar em outras atividades produtivas.

“...Tem catador que leva, mas eu acho que o certo é deixar os filhos estudar né..." (Jorge, 40 anos).

“...Eu acho que os jovens têm que estudar né. Estudar para amanhã ou depois que isso aí não é vida, isso aí é sofrer de mais. Então estou 3 anos aí ou mais com uma hérnia que vou operar, dificilmente vou no caranguejo só na última hora..." (Sergio, 42 anos).

\section{Tempo de residência}

O tempo de residência, a procedência dos entrevistados e a intenção de permanecerem vivendo no local foram questões pesquisadas entre os membros das comunidades selecionadas. A intenção de verificar estes aspectos não se restringiu apenas ao fato de se tratar de um lado relacionado ao apego que as pessoas desenvolvem para com o local, onde nasceram e/ou habitam (topofilia). A questão envolveu, também, as relações que dizem respeito aos laços familiares entre os que 
fixam raizes em determinada região. A condição de serem moradores locais há vários anos lhes confere a capacidade para "perceberem" o lugar, as mudanças que ocorreram com o tempo, os problemas e as potencialidades regionais.

Em relação ao tempo de residência no local pela população participante da pesquisa, percebeu-se que $38 \%$ da população residiam no mesmo local há 44 anos, sendo que a grande maioria (76\%) residia no mesmo local há 25 anos ou mais, de acordo com a tabela 6.

Tabela 6 - Distribuição do número e percentagem dos catadores de caranguejos segundo tempo de residência no local do estudo.

\begin{tabular}{ccc}
\hline $\begin{array}{c}\text { Tempo que reside no local } \\
\text { (em anos) }\end{array}$ & $\mathrm{N}$ & $\%$ \\
\hline $1 \vdash 5$ & 2 & 2 \\
$5 \vdash 10$ & 4 & 4 \\
$10 \vdash 15$ & 5 & 5 \\
$15 \vdash 20$ & 8 & 8 \\
$20 \longmapsto 25$ & 5 & 5 \\
$25 \longmapsto 30$ & 14 & 14 \\
$30 \vdash 35$ & 16 & 16 \\
$35 \longmapsto 40$ & 8 & 8 \\
$40 \vdash 45$ & 38 & 38 \\
\hline Total & 100 & 100 \\
\hline
\end{tabular}

O levantamento dos dados demonstrou que os catadores residiam no mesmo local há muitos anos, sendo que grande parte dos entrevistados afirmou ter nascido na região.

DEL RIO e OLIVEIRA (1998), descrevem o "lugar" como objeto de sentimento e o espaço como um objeto de pensamento. De acordo com os autores, moradores vivenciam o lugar; estudiosos pensam sobre o espaço. Moradores se 
sentem à vontade mergulhados na "ambiência" do lugar; estudiosos explicam o espaço como processo de evolução, portanto, em constante mudança.

Considera-se que a paisagem resulta da fusão entre os componentes naturais e construídos, com o cenário do mundo vivido, algumas de suas particularidades são conhecidas apenas por seus moradores, não sendo percebidas pelo viajante, que apenas passa por ela. Só quem tem a experiência, por meio de um contato direto e contínuo, poderá alcançar melhor compreensão dela.

Os catadores mais idosos vivenciaram a invasão do manguezal e o aterro da fonte de subsistência de suas famílias. Nessa época, a coleta dos caranguejos era feita próxima às residências dos catadores e existia fartura desse crustáceo. Além do que, eram poucas as pessoas que exploravam os recursos do manguezal.

Dentre os representantes mais idosos do grupo, foi localizado o Sr. Gilberto, 56 anos residente da Ilha das Caieiras, que declarou morar no local desde que nasceu. $\mathrm{Na}$ época da pesquisa, estava residindo sozinho, encontrava-se separado de sua esposa, com quem teve 3 filhos. Os mesmos não seguiram a profissão do pai, por opção própria, mas o desejo do patriarca era que os filhos continuassem o trabalho, ligado as suas raizes como povo lutador do mangue. Sua principal renda era a venda do caranguejo. Já havia trabalhado como empregado, mas relatou que preferia trabalhar no mangue, a liberdade que o mangue lhe proporcionava era mais forte do que o trabalho assalariado controlado por um patrão, com hora para entrar e sair, mesmo com a segurança de obter um salário certo no final do mês e outras garantias em relação aos direitos trabalhistas. Iniciou suas atividades no manguezal aos 10 anos de idade influenciado por familiares.

Esse representante do grupo de catadores, certamente guarda em sua memória, toda a história do grupo daquela região. Tratava-se de um personagem importante, para o resgate da cultura dos catadores de caranguejos do município de Vitória. 
Ficou registrado na memória dos catadores, o aniquilamento dos caranguejos, para dar espaço as pessoas que não tinham onde morar.

\section{Condições de moradia}

Outro aspecto que fơ pesquisado, diz respeito às residências dos catadores de caranguejos dos bairros selecionados, que são quase na sua totalidade, habitadas por seus proprietarios, conforme a tabela 7 .

Tabela 7 - Condiçỡes de moradia dos catadores de caranguejos.

\begin{tabular}{lcc}
\hline $\begin{array}{l}\text { Condições de moradia } \\
\text { Habítação }\end{array}$ & $\mathrm{N}$ & $\%$ \\
\hline Própría & 55 & 55 \\
Aluggada & 30 & 30 \\
Emprestada & 15 & 15 \\
\hline Total & 100 & 100 \\
\hline
\end{tabular}

Em torno de $55 \%$ dos caranguejeiros possuíam habitação própria. A maioria das construções era de tijolo, coberta por telhas e com piso de cimento. Os $45 \%$ restantes moravam em casas alugadas (30\%) ou emprestadas (15\%). A média de indivíduos nos domicílios fó de 6 pessoas, chegando até 17 pessoas por residência (Figura 02).

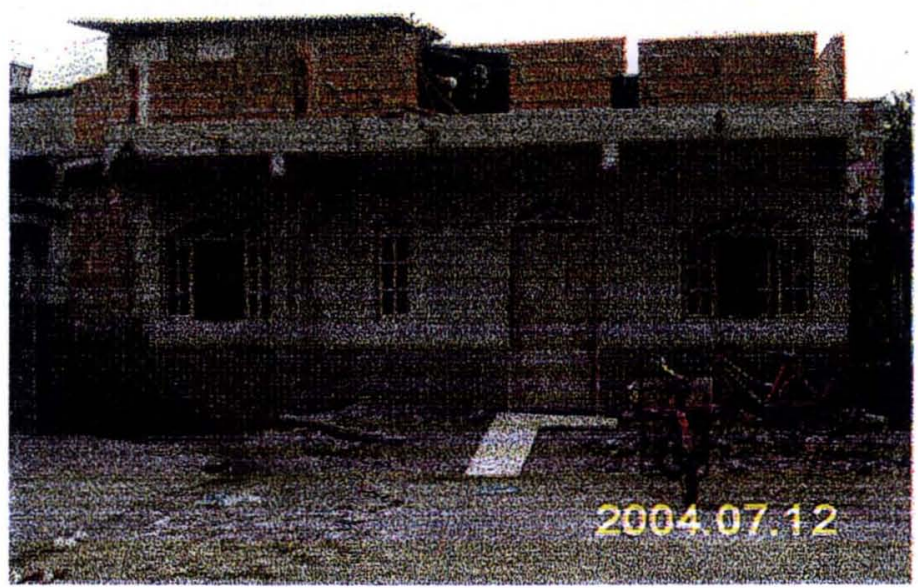

Figura 02 - Residência - bairro Maria Ortiz 
GARCIA (1999), descreveu as residências de pescadores do entorno da Lagoa da Conceição, Florianópolis, com respeito ao material e à condição de moradia. Segundo a autora, nessa área também foi encontrada a maioria absoluta de pessoas usufruindo o privilégio da casa própria $(98,4 \%)$, sendo que destas, $53,2 \%$ eram casas de alvenaria. Comenta, ainda, que esse quadro conduz a considerações sobre a seguinte questão: atualmente, a pesca como atividade em decadência, gerou no passado condições suficientes para que seus praticantes alcançassem, em grande parte, a possibilidade de obter sua casa própria, unicamente, pela atividade em si.

No municipio de Vitória, o cenário da cata do caranguejo também apresentou esta mesma realidade, no passado havia fartura de caranguejo, que possibilitou para alguns, a aquisição da casa própria.

Em relação aos aspectos ambientais, constatou-se que a Prefeitura Municipal de Vitória estava trabalhando para garantir com a quase totalidade a existência de condições essenciais para que houvesse um quadro de higiene básica satisfatória.

A condição de ser proprietário da casa onde mora, poderiam ser associadas outras características, que dizem respeito à infra-estrutura, normalmente, de responsabilidade pública quanto ao seu fornecimento e que proporcionam qualidade de vida aos habitantes favorecidos pela prestação desses serviços.

A companhia responsável pelo abastecimento de água no município de Vitória é a Companhia Espírito-Santense de Saneamento - CESAN, que é uma empresa de economia mista, enquadrada no regime jurídico de direito privado como sociedade anônima. $O$ trabalho da empresa consiste na captação, no tratamento e na distribuição de água, na coleta e no tratamento de esgotos, tratamento e destinação final do lixo e controle da incidência dos vetores no Espírito Santo, por delegação do Governo Estadual e de parte dos municípios em que atua. A CESAN está presente em 52 dos 78 municipios do Espírito Santo, sendo 6 na Região da Grande Vitória e 46 no interior. Em média, os serviços da companhia cobrem mais de $70 \%$ do Espírito Santo e cerca de $98 \%$ de todas as localidades por ela atendida. 
Com relação ao esgoto doméstico, os dejetos eram eliminados em vasos sanitários e lançados na rede de esgoto. CECCA (1997), relacionou o saneamento básico com a saúde da população, o que tornou essa questão, um dos mais importantes indicadores da qualidade ambiental de uma área urbana ou semi-urbana.

A garantia de consumo de água segundo padrões de potabilidade adequados é questão relevante para a saúde pública.

Diversos fatores podem comprometer a qualidade da água. $\mathrm{O}$ destino final do esgoto doméstico e industrial em fossas e tanque sépticos, a disposição inadequada de resíduos sólidos urbanos e industriais, postos de combustíveis e de lavagem e a modernização da agricultura representam fontes de contaminação das águas por bactérias e vírus patogênicos, parasitas, substâncias orgânicas e inorgânicas.

O consumo de água, os crustáceos e os bivalvos contaminados por agentes biológicos ou físico-químicos são associados a diversos problemas de saúde. Algumas epidemias de doenças gastrointestinais, por exemplo, têm como fonte de infecção a água contaminada.

VAROVESKA O, VERÇOSA C (1997), relataram como o consumo de bivalvos (mexilhões, ostras, berbigões) representava riscos à saúde pública, em função de serem espécies filtradoras e concentradoras de microorganismos e substâncias químicas presentes na água. Para a segurança do consumidor, o controle sanitário dos bivalvos exigia a adoção de medidas distintas às empregadas no controle de pescado, como a classificação e identificação da área de origem do produto e a depuração obrigatória.

Com relação ao lixo, os problemas que envolviam sua geração, o acondicionamento, a coleta, a disposição final e, em certos casos, a reciclagem, encontravam-se relacionados entre as maiores preocupações ao redor do mundo, em especial, nas grandes concentrações urbanas. De acordo com o Banco Nacional de Desenvolvimento Econômico e Social (BNDES), cerca de 59\% dos municípios 
brasileiros com mais de 80.000 habitantes utilizavam lixões ou vazas sem tratamento para depositar o lixo. Os demais $41 \%$, tratavam o lixo parcialmente, devido às limitações quanto à capacidade de tratamento.

O lixo da região onde foi realizado o estudo era coletado nos domicílios por uma empresa terceirizada que prestava serviço à Prefeitura Municipal de Vitória, transportado para a usina de triagem e compostagem de lixo de Vitória, que foi inaugurada em 8 de setembro de 1990, com capacidade para processar até 320 toneladas diárias de detritos (NOGUEIRA 1996). O funcionamento da "Usina de Lixo" deu destino adequado à significativa parcela de lixo gerado no município de Vitória, evitando que novas áreas de manguezais continuassem a ser ocupadas.

A concessionária responsável pela distribuição de energia elétrica em todo o estado do Espírito Santo é a Espírito Santo Centrais Elétricas SA - ESCELSA (a primeira concessionária estatal a ser desestatizada) que opera na região, abrangendo um espectro amplo de atendimento. Este serviço de infra-estrutura básica, da mesma forma que o de água e esgotos, está relacionado com a qualidade de vida da população beneficiária.

Constatou-se durante a pesquisa o interesse desta comunidade em adquirir eletrodomésticos modernos que facilitam o trabalho doméstico. Uma série deles, que compunha os equipamentos de cozinhas modernas, também faziam parte dos aparelhos elétricos das famílias dos catadores de caranguejos. Todas as residências visitadas dispunham de geladeira e televisão. Algumas, possuíam, ainda, máquina de lavar roupas, liquidificadores e batedeiras, o que caracteriza uma mudança gradativa da forma de lidar com as tarefas do lar. Contudo, embora tivessem fogão a gás nas residências, o fogão à lenha ainda era utilizado por boa parte das famílias entrevistadas, como alternativa para diminuir o consumo de gás (figura 03). 


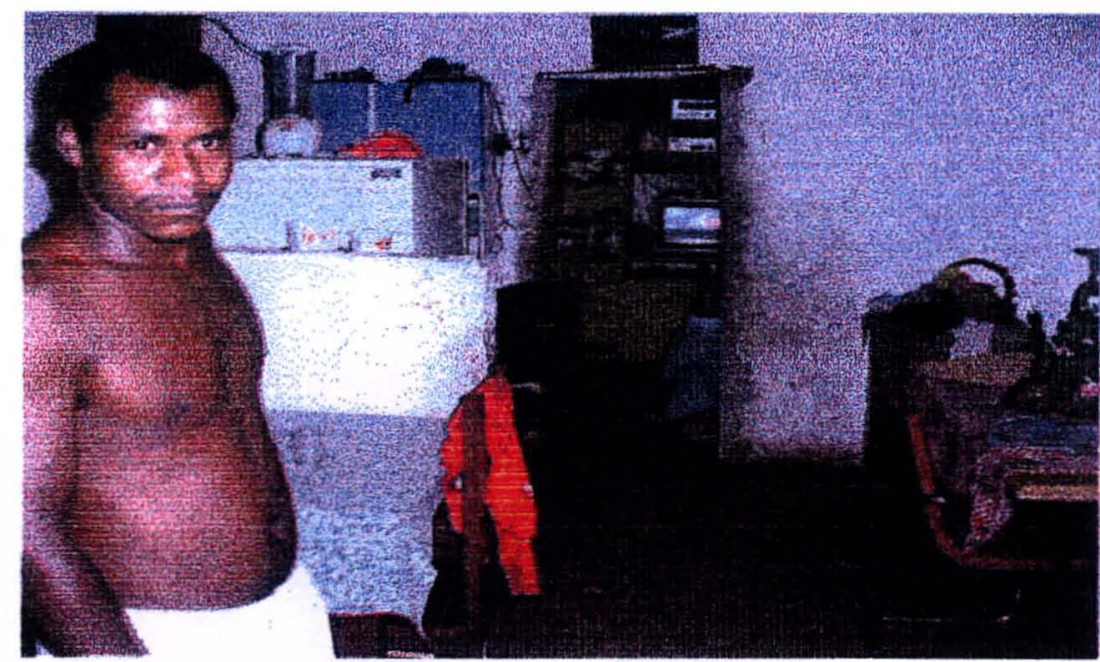

Figura 03 - Destaque da cozinha (Bairro Grande
Vitória)

Todas as residências possuíam energia elétrica, porém, nem todas estavam dentro dos padrões de exigência da Espírito Santo Centrais Elétricas SA ESCELSA. Muitos, para se isentarem do pagamento das taxas, interligaram suas casas diretamente na rede oficial, o que é popularmente conhecido como "gato" (ligação clandestina para consumir energia elétrica sem pagar).

\section{Renda familiar}

A maioria dos catadores de caranguejos vivia exclusivamente da cata do caranguejo-uçá, ou seja, retirava sua sobrevivência e a da família da captura desse crustáceo. Dos entrevistados, $14 \%$ relataram receber outro tipo de rendimento, como aposentadoria e seguro desemprego. Os demais $76 \%$ informaram que não recebiam nenhum outro tipo de rendimento.

Dos catadores entrevistados, $56 \%$ recebiam entre um e dois salários mínimos, $24 \%$ recebiam entre três e cinco salários mínimos, enquanto $20 \%$ recebiam somente um salário mínimo. Esses dados mostram que a renda familiar média era bastante baixa (Figura 04). 


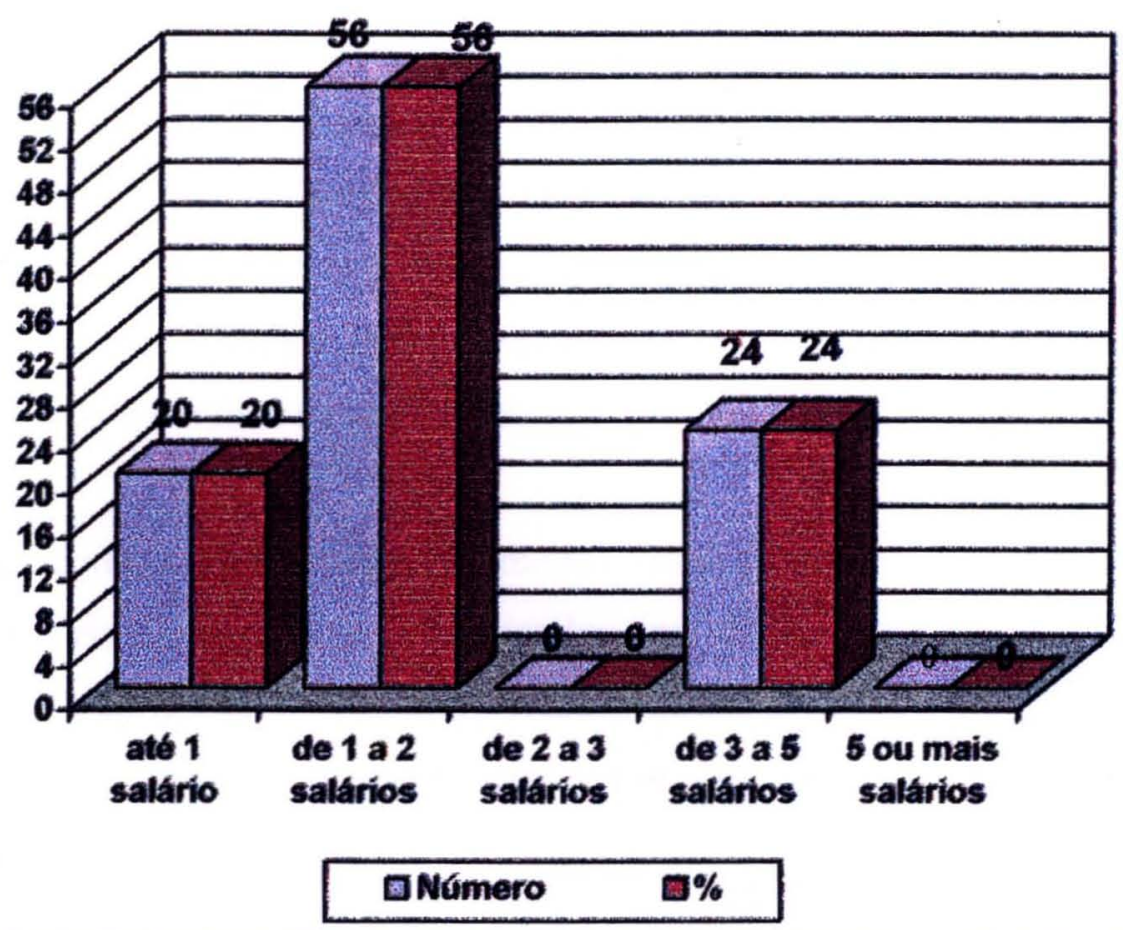

Figura 04 - Distribuição dos catadores de caranguejos segundo a renda familiar média.

Segundo RODRIGUES (2000), em sua pesquisa na Baía de Babitonga (SC), a ocorrência de caranguejo Uçá (Ucides Cordatus) fó observada, como sendo sua cata nos bosques do manguezal, uma atividade geradora de renda expressiva para as comunidades de pescadores artesanais na regiäo.

$\mathrm{Na}$ época da pesquisa, $80 \%$ dos catadores não tínham outra atividade além da cata do caranguejo, 20\% dos catadores tinham outra atividade e ocupavam funções como pedreiro $5 \%$, jardineiro $2 \%$, vigilante $2 \%$, funcionário de supermercado $2 \%$, carpinteiro $9 \%$ e com a prática dessas atividades ainda sobrava tempo para que eles se organizassem e freqúentassem o mangue. Alguns dos entrevistados dísseram não conseguir outra fonte de renda por diferentes razões: idade avançada, doenças variadas, baixo nível de instrução e dificuldade em conseguir emprego.

Essas informações mostram que parte dos catadores entrevistados buscava uma fonte alternativa de subsistência e, ao mesmo tempo, a maior segurança no trabalho assalariado. 
A inexistência de garantias para o futuro foi uma das dificuldades mais importantes citadas pelos catadores de caranguejos com respeito à atividade de catação considerada pelo grupo como um trabalho muito pesado e que exige muito sacrificio. Apesar desse sentimento generalizado, $80 \%$ da população estudada disseram estar satisfeitas com a ocupação de catador e não pretendiam mudar. Essa postura parece estar ligada à sensação de liberdade e à possibilidade de ganhar mais dinheiro do que em trabalhos assalariados.

De acordo com os dados levantados, $68 \%$ dos entrevistados já trabalharam com registro em carteira, foram empregados com carteira assinada e $32 \%$ relataram nunca terem sido fichados. Dos entrevistados que relataram ter trabalhado fichados, $12 \%$ permaneceram no emprego por um período de até dois anos e os demais por periodos inferiores.

A Secretaria Municipal de Meio Ambiente da Prefeitura de Vitória desenvolve desde 1998, por meio do Projeto de Gestão Sustentável da Pesca de Caranguejos e Guaiamuns, ações de fiscalização, monitoramento e educação ambiental, tendo como principal objetivo garantir a proteção essencial à reprodução e à continuidade dessas espécies, pois representam fonte de alimento e renda para muitas famílias.

Em função desse projeto, foi criada em 27 de Julho de 1998, a "Portaria 000104", publicada pelo IBAMA - Instituto Brasileiro do Meio Ambiente e dos Recursos Naturais Renováveis que determina o tamanho mínimo de captura do caranguejo e proíbe a cata em determinados períodos.

Durante o período da "andada", época de reprodução dos caranguejos, e do "defeso", periodo do ano em que o caranguejo troca seu casco para poder crescer, os catadores ficam proibidos de capturar e comercializar o caranguejo. Devido a isso, esses profissionais ficam sem fonte de renda. A maioria não é cadastrada no IBAMA - Instituto Brasileiro do Meio Ambiente e dos Recursos Naturais Renováveis ou DFA - Delegacia Federal de Agricultura e no INSS - Instituto Nacional de 
Seguridade Social, não possui, portanto, direito ao Seguro Desemprego, referente a um salário mínimo, o que acarreta sérios problemas sociais aos catadores e seus familiares.

“...Sim, minha atividade é fazer um biscate, quando acho uma mudança para fazer, é o que eu tenho que fazer. Ultimamente eu não estou podendo fazer, que minha mulher faleceu e eu tenho que cuidar dos meninos. Estou mais pescando de noite..." (Jorge, 40 anos).

“...O que tiver a disposição para mim, oficina de serralheria, supermercado, qualquer coisa, ajudante de pedreiro..." (Marcos, 23 anos).

\subsection{Envolvimento da população em estudo nessa atividade}

O tempo de trabalho no mangue apresentou uma grande variação, indo de 3 a 40 anos. As maiores freqüências ocorreram entre os que trabalhavam havia 25 e 26 anos, ambos com 10\%, e que trabalhavam havia 3 e 15 anos, ambos com $8 \%$ (tabela 8).

Tabela 8 - Número de catadores de caranguejos segundo tempo de trabalho no mangue.

\begin{tabular}{ccc}
\hline Tempo de trabalho (em anos) & $\mathrm{N}$ & $\%$ \\
\hline $1 \vdash 10$ & 22 & 22 \\
$10 \vdash 20$ & 28 & 28 \\
$20 \vdash 30$ & 34 & 34 \\
$30 \vdash 40$ & 16 & 16 \\
\hline Total & 100 & 100 \\
\hline
\end{tabular}

“... Na cata do caranguejo ta com vai fazer 30 anos..." (Jorge, 40 anos). 
“...Desde 1996..." (Marcos, 23 anos).

“...Desde 14 anos, vou fazer 43 anos agora..." (Sergio, 42 anos).

De acordo com SILVA (2004), as comunidades pesqueiras da Ilha das Caieiras faziam largo uso do pescado e ocupavam amplamente o espaço do manguezal, estabelecendo durante séculos, uma importante área de uso comum e mantendo com este ecossistema uma relação que extrapola a questão de subsistência integrando atividades de lazer, transmissão de patrimônio, sociabilidade e construção de uma identidade social local amplamente definida pelo saber e o fazer da pesca. Dentre as relações que estão presentes na pesca no manguezal, as técnicas utilizadas na captura de diferentes tipos de pescado revelavam um saber especializado que indicava uma interação entre a comunidade e o ambiente.

Um número expressivo de catadores, ou seja, $52 \%$ trabalhavam durante 4 dias da semana no mangue, $24 \%$ durante 3 dias e $12 \%$ durante cinco dias (tabela 9 ).

Tabela 9 - Número de catadores de caranguejos de acordo com a quantidade de dias da semana trabalhados.

\begin{tabular}{lrr}
\hline Dias da semana & $\mathrm{N}$ & $\%$ \\
\hline 1 dia & 2 & 2 \\
2 dias & 4 & 4 \\
3 dias & 24 & 24 \\
4 dias & 52 & 52 \\
5 dias & 12 & 12 \\
6 dias & 2 & 2 \\
7 dias & 4 & 4 \\
\hline Total & 100 & 100 \\
\hline
\end{tabular}

“...Dependendo da maré, seis horas à oito horas, depende da maré, na maré grande quatro horas, na maré morta dá pra ficar até oito horas..." (Jorge, 40 anos). 
“...Seis horas..." (Marcos, 23 anos).

“...Cinco horas..." (Sergio, 42 anos).

De acordo com a tabela $10,70 \%$ dos catadores trabalhavam em diversos dias da semana, exceto sábado e domingo. Somente $30 \%$ informaram, portanto, que trabalhavam sábado e domingo.

Tabela 10 - Distribuição do número de catadores por dia da semana trabalhados.

\begin{tabular}{lrr}
\hline Dias da semana & $N$ & $\%$ \\
\hline $2^{\mathrm{a}}, 3^{\mathrm{a}}, 5^{\mathrm{a}}$ e $6^{\mathrm{a}}$ & 6 & 6 \\
$3^{\mathrm{a}}, 4^{\mathrm{a}}, 5^{\mathrm{a}}$ e $6^{\mathrm{a}}$ & 30 & 30 \\
$4^{\mathrm{a}}, 5^{\mathrm{a}}$ e $6^{\mathrm{a}}$ & 22 & 22 \\
$3^{\mathrm{a}}, 4^{\mathrm{a}}$ e $5^{\mathrm{a}}$ & 2 & 2 \\
$2^{\mathrm{a}}, 3^{\mathrm{a}}, 4^{\mathrm{a}}, 5^{\mathrm{a}}$ e $6^{\mathrm{a}}$ & 10 & 10 \\
Outros & 30 & 30 \\
\hline Total & 100 & 100 \\
\hline
\end{tabular}

A quantidade de caranguejos coletados pelos catadores está representada na tabela 11. Cada catador de caranguejo coletava, em média, 23,06 dúzias de caranguejo por semana. A partir do diário de campo, foi possível verificar que durante o verão a quantidade era sempre maior. A partir do final do outono, durante o inverno e no início da primavera a quantidade caía para quase metade da quantidade esperada. 

Tabela 11 - Distribuição do número de catadores de caranguejos segundo a quantidade de dúzias coletadas.

\begin{tabular}{ccc}
\hline Quantidade de dúzias & $\mathrm{N}$ & $\%$ \\
\hline $1 \vdash 10$ & 20 & 20 \\
$10 \vdash 20$ & 9 & 9 \\
$20 \vdash 30$ & 30 & 30 \\
$30 \vdash 40$ & 8 & 8 \\
$40 \vdash 50$ & 1 & 1 \\
$50 \vdash 60$ & 3 & 3 \\
\hline Total & 71 & 71 \\
\hline
\end{tabular}

De acordo com os dados obtidos por meio das anotações no diário de campo, os entrevistados afirmaram na sua totalidade que costumavam capturar somente os caranguejos machos. Era quase um consenso que as fềmeas não deveriam ser capturadas.

Segundo GODELIER (1978), um fenômeno natural só se torna um recurso a partir da combinação de duas condições: deve ser direta ou indiretamente capaz de satisfazer uma necessidade humana e ter alguma utilidade social. Além disso, o homem precisa desenvolver os meios técnicos para extrair coisas da natureza e fazêla servir às suas necessidades, ou seja, deve ter uma certa interpretação do ambiente em volta de si, para ser capaz de combinar os meios intelectuais com os materiais, de modo a atuar sobre ele para dele conseguir sua própria reprodução fisica e social.

Dentre as técnicas de captura do caranguejo, $90 \%$ dos catadores disseram utilizar o braço enquanto $10 \%$ disseram utilizar a redinha. A maioria, $58 \%$ dos catadores justificaram a sua preferência pela técnica utilizada, pois a mesma preserva as espécies (figura 05). 


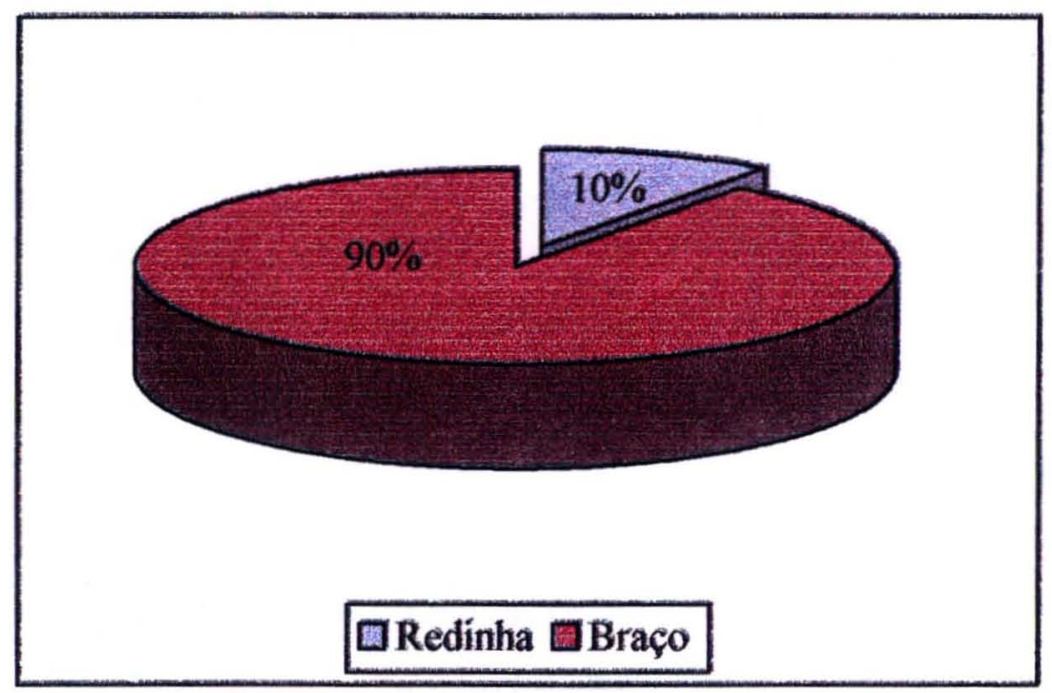

\section{Figura 05 - Técnicas utilizadas para a captura do caranguejo-uçá (ucides cordatus) no município de Vitória (ES).}

As afirmações passaram a não ser em sua totalidade confiáveis, a partir do momento em que se constatou nas visitas de campo algumas redinhas, esquecidas no mangue. Quando questionados sobre as mesmas, responderam ser a maioria utilizada por pessoas desempregadas que tentam retirar o sustento do mangue a qualquer custo.

Não se observou a incorporação definitiva do uso da "redinha", que tem agravantes adicionais como os de não ser reutilizável permanecendo no ambiente.

Os catadores de caranguejo em geral são surpreendentemente conservadores, existem casos documentados em que a inovação era muito mais rejeitada do que aceita, provavelmente por ser incompatível com o modelo cultural do grupo.

De acordo com DIEGUES (1988), o pescador artesanal possui um acervo mental acerca da dinâmica dos recursos pescados que é transmitida de pai para filho e que o credencia a refutar ou incorporar inovações.

MALDONADO (1986), em sua obra sobre pescadores do mar, afirmou que dispondo de seu próprío cabedal de informações e representações, eles eram 
plenamente capazes de avaliar e opinar adequadamente sobre a viabilidade de novos elementos tecnológicos.

Segundo FORMAN (1970), a resistência à introdução de uma nova tecnologia de pesca entre os pescadores jangadeiros da Bahia era atribuida a decisões tomadas por autores individuais, que perceberam que teriam menor parte na divisão da coleta, se ela fosse aumentada pela utilização de barcos maiores.

BEGOSSI (1989), também se referiu às decisões individuais dos pescadores para explicar a aceitação da "lambreta", tecnologia de pesca introduzida na região de Búzios para a captura da anchova. Segundo ela, os pescadores se basearam no interesse imediato de maximização da produção, mesmo sabedores que esta tecnologia representava um grande risco para a comunidade.

De acordo com AGNEU (1981), isso significa admitir que prováveis mudanças no ambiente não refletem numa adaptação coletiva automática, mas antes disso, parecem promover uma série de ações e reações individuais, no curso das quais imerge alguma organização comunitária.

Segundo CARRERA (1977), desde os primórdios do descobrimento da América por Cristóvão Colombo em 1492, os indigenas já utilizavam na sua alimentação ostras, peixes, crustáceos e moluscos, consideravam o manguezal como um ecossistema altamente produtivo e dele se beneficiaram ao máximo, de acordo com o conhecimento que possuíam.

Dos catadores de caranguejos entrevistados, $66 \%$ costumavam comer o caranguejo e os demais $34 \%$ não o consumiam, devido ao longo tempo que o faziam, considerando o seu sabor intolerável e o longo período gasto para consumir o que significava segundo eles tempo perdido de trabalho (figura 06). 


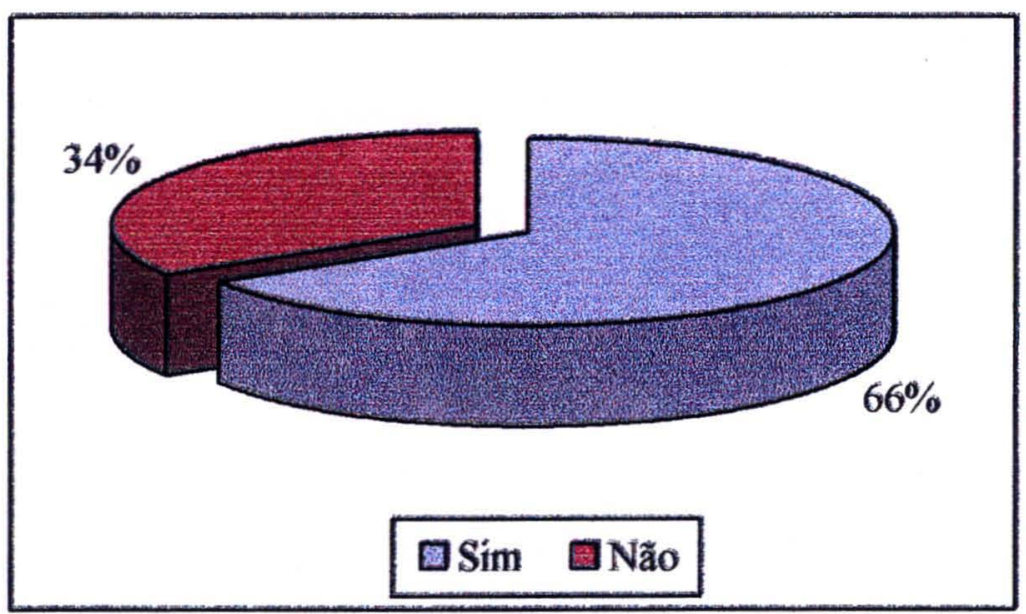

Figura 06 - Quanto à utilização do caranguejo para o consumo próprio no município de Vitória (ES).

Dos catadores de caranguejos estudados, $84 \%$ afirmaram capturar outros produtos do mangue, apresentando maior expressividade na captura de siri (18\%), peixes $(16 \%)$, ostra e sururu $(13 \%)$ e somente sururu $(12 \%)$.

Somente $16 \%$ dos catadores afirmaram não capturar outro produto do mangue, justificando não se identifícarem com outras atividades de captura se não a do caranguejo (Figura 07).

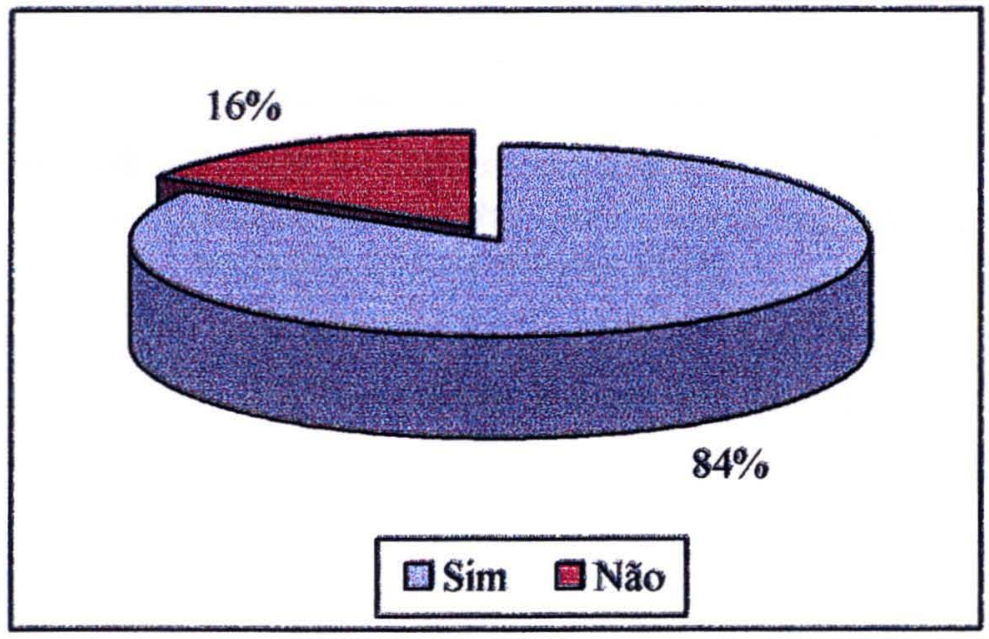

Figura 07 -Catadores de caranguejos que coletavam outros mariscos no municipio de Vitória (ES). 
Em relação à utilização dos mesmos, 35\% responderam utilizar os produtos para sua própria alimentação, enquanto $49 \%$ comercializavam os produtos para complementação da fonte de rendimento.

\section{Organização social}

Disseram fazer parte de alguma associação, afirmando ser importante participar dela $76 \%$ dos catadores de caranguejos, em função dessas associações trazerem benefícios para os associados, ensinando coisas novas, ajudando na resolução de problemas e dando a eles segurança. Já os outros $24 \%$ dos catadores nunca participaram, dizendo não ter interesse na associação, pois achavam que era desorganizada e por consumir muito de seu tempo (Figura 08).

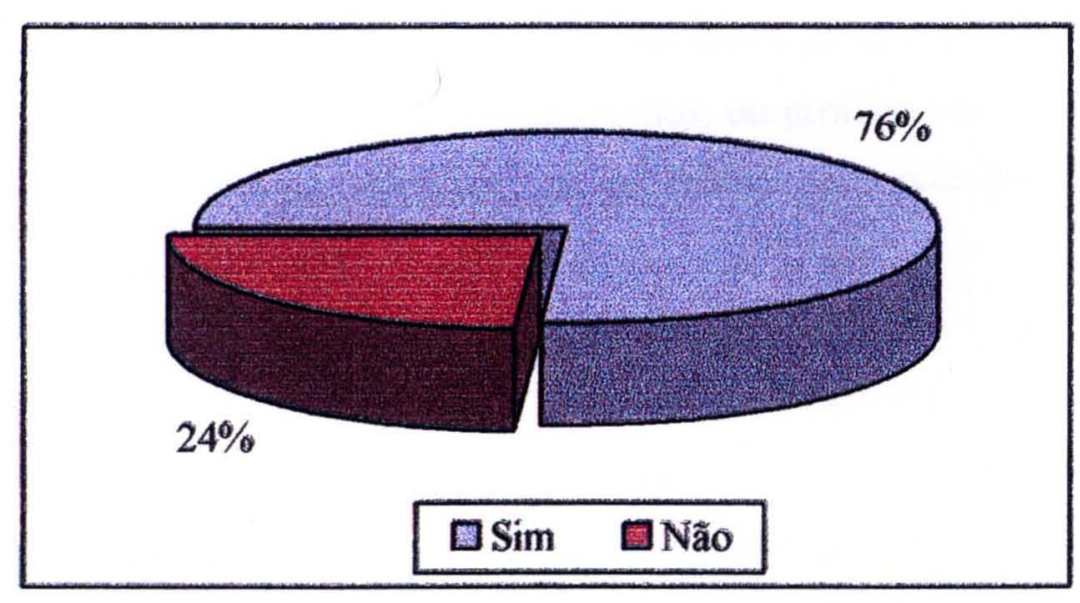

Figura 08 - Quanto ao registro em órgãos ou associaçôes ligadas à cata do caranguejo no município de Vitória (ES).

A maioria dos catadores acreditava que os organismos públicos estavam interessados na melhoria das condiçő̃es de vida, das várias categorias sociais inseridas no processo de reprodução da atividade pesqueira em geral.

Nos bairros onde os catadores residiam constatou-se que existiam associações de moradores, marisqueiros, catadores, comerciantes, pescadores, sindicatos, cooperativas e colônias de pescadores, que eram associações profissionais, daqueles que faziam da cata de caranguejos a sua profissão, ou meio principal de vida. 
À época da coleta de dados, $68 \%$ dos entrevistados concordavam que essas organizações auxiliavam na solução de problemas, argumentando que há união entre os catadores e que a associação corria atrás dos interesses, ajudava a esclarecer dúvidas e a resolver problemas da comunidade, como a instalação de creches e postos de saúde. Já $32 \%$ dos catadores discordavam, dizendo que as organizações existentes em seus bairros não traziam nenhuma melhoria à população.

Observou-se que a informação é importante para a sensibilização da comunidade, mas a pedagogia exclusivamente informativa não motivava os catadores a buscarem soluções para os problemas da sociedade que, de alguma forma os atingiam.

Segundo a consolidação das Leis do Trabalho - CLT, é lícita a associação dos seus interesses econômicos ou profissionais de todos os que, como empregadores, empregados, agentes ou trabalhadores autônomos, ou profissionais liberais, exerçam respectivamente, a mesma atividade ou profissão ou atividades ou profissões similares ou conexas (art. 511).

A Associação dos Catadores de caranguejos, fundada pelos caranguejeiros do bairro Maria Ortiz e Jabour, surgiu com o objetivo de promover o desenvolvimento da atividade da cata do caranguejo por meio da união dos catadores de caranguejo. Era a forma de eles adquirirem recursos financeiros e materiais junto às instituições governamentais como prefeituras sedes estaduais e organismos federais.

Destaca-se a prevalência do trabalho em equipe na medida em que nele os conhecimentos são enriquecidos pelo de outros companheiros. É, geralmente, no grupo que o individuo toma consciência do trabalho coletivo, o que contribui para a compreensão da essência da ação democrática.

A associação vivenciou tempos conturbados, ocasionados por desavenças entre os associados. Observou-se a falta de integração entre os componentes da associação, talvez pela ausência de um profissional para dar apoio necessário, na tomada de 
decisões. O último presidente deu um desfalque na conta bancária da associação, como conseqüência, alguns dos catadores têm claro em suas mentes que o erro foi de todos, pois não havia união no grupo e o comando da associação foi entregue nas mãos de um único representante.

“...A minha opinião sobre a associação seria uma coisa assim, para um ajudar o outro, sem prejudicar o outro, mas quando eu cresci e vi que já cresceram o olho em dinheiro, fiquei de sair fora, e sai fora. Que eu queria fazer um trabalho pra um ajudar o outro, que acho que associação é uma entidade humana pra um ajudar o outro, mas quando eles começaram a crescer os olhos em dinheiro eu peguei e saí fora disso aí. Meu objetivo era ajudar eles..." (Jorge, 40 anos).

“...Na minha opinião, não teve uma associação que teve firmeza para ajudar os catadores, sempre só entrou ladrão, que pegava a merrequinha que tinha lá dentro, até hoje não deu certo não..." (Marcos, 23 anos).

“...Tem que ter, é bom para organizar...” (Sergio, 42 anos).

\subsection{Conseqüências ambientais}

De acordo com $82 \%$ dos catadores de caranguejos entrevistados, a fiscalização do governo na área do manguezal é efetiva, pois os fiscais estão mais atentos aos problemas do mangue, o controle está mais eficaz e, conseqüentemente, o ambiente do mangue tem melhorado para as comunidades que vivem dele.

Dentre as inúmeras queixas apresentadas pelo restante do grupo (18\%) todas reverteram de alguma forma ao problema de fiscalização. Reivindicavam uma fiscalização mais assídua, menos repressora com a classe, mais imparcial e preparada. Cobravam a presença da autoridade pública, necessária para coibir os abusos praticados no mangue e que o governo não dava a eles um apoio financeiro durante o período da proibição da captura do caranguejo. 
No município de Vitória, mesmo com a existência de órgãos, entidades governamentais, seguimentos representativos da sociedade, que tratam a questão da educação ambiental, continua a não existir uma política ambiental que contenha a destruição de significativos ecossistemas.

Em relação às mudanças percebidas pelos catadores referente à cata do caranguejo ressalta-se a diminuição das áreas de mangue, o aumento do número de pessoas sobrevivendo da captura dos caranguejos e a utilização da redinha, classificada pelos próprios catadores de caranguejos como predatória. $\mathrm{O}$ conjunto dessas mudanças acarretou o declínio da quantidade de caranguejos existentes nos manguezais de Vitória.

Entre os entrevistados, $40 \%$ sentiram diferença na qualidade da água da baía de Vitória, enquanto $60 \%$ relataram não sentir nenhuma diferença. $O$ problema levantado pelos catadores foi em relação ao lixo que era depositado pelos próprios moradores, aumentando a poluição da água.

Esses depoimentos indicam o princípio de uma tomada de consciência, se considerada como consciência o fato de o indivíduo assumir o seu papel de sujeito no contexto de desenvolvimento humano geral. Para tanto, a incorporação de atitudes ambientais positivas significa um compromisso com a realidade social.

Esse aspecto reforça a necessidade de operar junto às comunidades locais trabalhos de conscientização. Neste sentido, a educação ambiental desempenha papel fundamental tanto no campo individual, quanto no coletivo, buscando por meio da disponibilização de informações e do diálogo, sensibilizar diferentes grupos sobre a importância dos hábitos e atitudes para utilização do meio natural e seus recursos e, como estes refletem no todo e interferem na qualidade da vida humana.

CARMO (1987), fez uma análise das características físico-quimicas e biológicas dos manguezais localizados ao norte da baía de Vitória (ES) e dos índices 
de contaminação a que está sujeita a fauna e a flora. Em estudos realizados quanto aos indices de contaminação em carne de sururu (Mytella charruana e Mytella guyanensis) recolhidos na baía de Vitória, encontrou altos índices de coliformes fecais $(0,36$ a $2.400 \mathrm{nmp} / 100 \mathrm{ml})$, o que evidenciou um elevado grau de contaminação por dejetos humanos.

A fiscalização destacou-se como um assunto crucial em todas as manifestações populares e merece ser analisada, com maior detalhamento. Isto porque, ninguém consegue compreender qualquer processo de gestão, em que os infratores das regras determinadas, não sejam exemplarmente punidos. Tão pouco se concebe a fiscalização que pune aquele infrator que comete um delito, muitas vezes para saciar a fome, enquanto que grandes usurpadores do meio ambiente, quase sempre são poupados de qualquer penalidade sobre seus atos, cujas dimensões são infinitamente maiores.

Em 2003, ano do levantamento dos dados para a presente pesquisa, constatouse que a fiscalização durante o período de defeso do caranguejo e do guaiamum foi executada de maneira mais rígida e integrada entre o IBAMA, prefeituras e Polícia Ambiental.

O esquema montado teve como objetivo realizar o monitoramento ao longo dos manguezais do Espírito Santo. Foi firmada uma parceria com a Polícia Rodoviária Federal para que os caranguejos vindos do Estado da Bahia, também fossem fiscalizados. A operação, denominada "Pente Fino", retia os caranguejos para averiguação das notas fiscais. Os fiscais do IBAMA do Espírito Santo confirmavam a procedência dos caranguejos com o IBAMA do Estado da Bahia.

O IBAMA determinou que todos os catadores de caranguejos que tivessem estoque do crustáceo congelado ou cozido (estocar vivo é proibido) teriam que registrar os mesmos na sede do IBAMA até uma semana antes do inicio do "defeso". 
A Polícia Ambiental chegou a efetuar várias prisões durante o defeso e a cobrança da fiança foi de $\mathrm{R} \$ 700,00$ (setecentos reais) para libertação dos catadores que infligiram a lei.

Os órgãos competentes para fazer a fiscalização do mangue têm efetuado um bom trabalho junto às comunidades de catadores em relação às ações de fiscalização, monitoramento e educação ambiental, porém, medidas alternativas devem ser criadas para sustentar essas famílias durante o período de proibição da captura do caranguejo.

$\mathrm{O}$ fato de um maior número de pessoas encontrarem-se envolvidas com a atividade, pode ser indicador de um quadro de dificuldades sócio-econômicas existente na região do estudo, a exemplo do que vem ocorrendo em todo país, com a conseqüente retração do mercado de trabalho, o que obriga a muitos buscarem alternativas de subsistência em outras atividades produtivas.

As tintas anti-incrustantes utilizadas na pintura das embarcações, no processo de manutenção das mesmas, representam uma fonte de mercúrio para o meio ambiente, que pode ser convertido por bactérias a compostos orgânicos, muito mais tóxicos (metil-mercúrio). Não existia por parte dos catadores a preocupação quanto à contaminação dos recursos naturais oriundos do mangue em relação ao mercúrio, pois os catadores desconhecem as propriedades que compõem a tinta antiincrustante.

Dos catadores de caranguejos entrevistados, $60 \%$ afirmaram que o número de catadores aumentou consideravelmente e que em sua maioria eram pessoas desempregadas, que tentam tirar o seu sustento do mangue, já $16 \%$ não notaram nenhuma diferença e os $24 \%$ restantes não souberam responder a pergunta. 
Tabela 12 - Numero de catadores atuando na região.

\begin{tabular}{lrr}
\hline $\begin{array}{l}\text { Catadores atuando na } \\
\text { região }\end{array}$ & $\mathrm{N}$ & $\%$ \\
\hline aumentou & 60 & 60 \\
não sabe & 24 & 24 \\
ficou igual & 16 & 16 \\
diminuiu & 0 & 0 \\
\hline Total & 100 & 100 \\
\hline
\end{tabular}

Os catadores de caranguejos, quando questionados sobre a responsabilidade da comunidade junto ao poder público diante do quadro político atual, entre os entrevistados $76 \%$ afirmaram que quem deveria tomar conta do manguezal era a própria comunidade que sobrevivia às custas dos seus recursos naturais. Já os $24 \%$ restantes acreditavam que os cuidados com o manguezal eram de responsabilidade do governo.

O local de trabalho foi descrito por $56 \%$ dos catadores como sendo satisfatório. Essa porcentagem reflete a opinião dos catadores mais antigos, que tinham o manguezal como uma possível fonte de alimento e renda para o sustento futuro de sua família. Já $27 \%$ dos entrevistados descreveram o seu local de trabalho como destruído pelo próprio catador. Essa porcentagem reflete a opinião dos catadores mais jovens, que só se importavam com o ganho imediato, não se preocupando com a preservação desse recurso para as futuras gerações. Os 17\% restantes afirmaram que o seu local de trabalho era muito perigoso.

\subsection{Agravos à saúde dos catadores}

Para a avaliação dos agravos à saúde dos catadores de caranguejos, decorrentes do esforço despendido na locomoção, captura e transporte dos caranguejos dentro do manguezal e também das condições insalubres do ambiente de trabalho, utilizou-se os dados levantados na ficha para anamnese, que foi utilizada 
para o levantamento e fichamento dos dados sobre a saúde dos catadores de caranguejos.

\section{Avaliação física}

Em relação à avaliação física, 7,6\% referiram sentir dores na coluna; $6 \%$ de dor nos ombros; $4 \%$ de dor no quadril; $2,25 \%$ de insônia; $2 \%$ de câimbra no abdômen; $2 \%$ de dores de cabeça; $2 \%$ de dor nos braços; $1,2 \%$ dores nos rins; $1,2 \%$ reclamou de varizes; $1,2 \%$ de câimbra nos membros superiores; $1,2 \%$ de stress; $1,2 \%$ de dor no tórax e $1 \%$ de mãos inchadas. Constatou-se um caso de desequilíbrio mental.

No levantamento dos distúrbios cardiovasculares constatou-se que 14 (35\%) sentiam dores no peito; $9(22,5 \%)$ sentiam falta de ar ao fazer exercícios leves; 7 $(17,5 \%)$ catadores aferiam a pressão arterial com freqüência e $2(5 \%)$ que usavam marcapasso ou prótese cardíaca.

Com relação aos distúrbios respiratórios, 7 (17,5\%) apresentavam tosse persistente causada pelo cigarro e $5(12,5 \%)$ tinham dificuldade de respirar. As queixas referentes a dores de cabeça freqüentes estavam relacionadas, segundo os catadores, às brigas em família.

De acordo, com ITO e colaboradores (1998), o consumo de cigarro era lícito e razoavelmente aceito em nosso país. A substância contida nos cigarros que mantém a dependência, é a nicotina, que é um estimulante poderoso que atinge o cérebro cerca de vinte segundos depois de um cigarro ser tragado.

A dependência da nicotina era isoladamente a principal causa evitável de mortes prematuras, causando três milhões de mortes no mundo inteiro a cada ano, provocadas por cânceres e doenças vasculares decorrentes do cigarro (ROBINS e REGIER 1991) 
Em relação aos hábitos de vida $47,5 \%$ dos participantes fumavam regularmente e destes, um revelou ser usuário de drogas ilícitas. Entre os que referiram ingestão de bebida alcoólica ( $\mathrm{n}=35$ catadores ou $87,5 \%$ dos participantes), afirmaram beber socialmente. Destes, 2 (5\%) apresentaram distúrbios gastrointestinais (vomitaram sangue) devido ao excesso de álcool no organismo.

Somente o abuso e a dependência de álcool atingiam cerca de 10 a $15 \%$ dos adultos do Ocidente, sendo a principal causa de acidentes graves, mortes violentas e doenças hepáticas e gastrointestinais. $\mathrm{O}$ álcool era uma das drogas mais utilizadas em nosso país. Estimava-se que era consumida por mais de $70 \%$ dos adultos. Um quarto desse total desenvolvia abuso ou dependência em algum período da vida (ROBINS e REGIER 1991).

“...Bebo uma cervejinha, uma pinga. Quando chego da maré bebo mesmo, não adianta mentir..." (Jorge, 40 anos).

“...De vez em quando eu bebo..." (Sergio, 42 anos).

“...É beber com comportamento, saber o que esta fazendo, erguer a cabeça e fazer o que é certo. É não perder a cabeça, ter responsabilidade naquilo que esta fazendo..." (Jorge, 40 anos).

“..Quem bebe uma vez ou outra, fim de semana, não todo dia...” (Sergio, 23 anos).

O álcool é um depressor do sistema nervoso central com efeitos sedativos e hipnóticos; a liberação de dopamina e peptídeos opióides no sistema nervoso central parece mediar alguns de seus efeitos prazerosos. A síndrome de abstinência alcoólica pode ser bastante desconfortável. Tipicamente, inicia-se nos dois primeiros dias depois do último gole, com ansiedade, irritabilidade, insônia, tremores, náuseas. Quando grave, pode evoluir com convulsões e delirium tremens (ITO e col. 1998). 
Não é demais afirmar que a proposição de desenvolver os conceitos e métodos da ergonomia no campo da saúde do trabalhador esbarra em suas carências epistemológicas acerca dos fundamentos metodológicos que sustentam as suas pesquisas ao tempo que contribui para contorná-las, pois fornecem elementos sobre o trabalho, os trabalhadores e a saúde. Criar novas abordagens é parte de um processo que pretende contribuir para as práticas preventivas dos danos à saúde relacionados ao trabalho e abre as vias para formulações futuras mais complexas.

Para a escola de ergonomia francesa, atividade de trabalho designa a maneira do ser humano mobilizar as suas capacidades para atingir os objetivos da produção. Tem-se como pressuposto que o trabalho convoca o corpo inteiro e a inteligência para enfrentar o que não é dado pela estrutura técnico-organizacional, configurandose como um dos espaços de vida determinantes na construção e na desconstrução da saúde (ASSUNÇÃO 1998).

A realidade atual exige dos pesquisadores envolvidos com a temática da saúde maiores esforços para compreender as mudanças recentes, pois a maneira das pessoas fazerem uso de suas capacidades fisicas, cognitivas e afetivas para produzir, foi transformado. Os catadores de caranguejos, além de aprenderem as técnicas de locomoção, pois o solo é mole e lamacento, precisam ter preparo físico e habilidade para andar na lama cerca de quatro horas por dia e carregar um saco com até dez dúzias de caranguejo (Figura 09). 


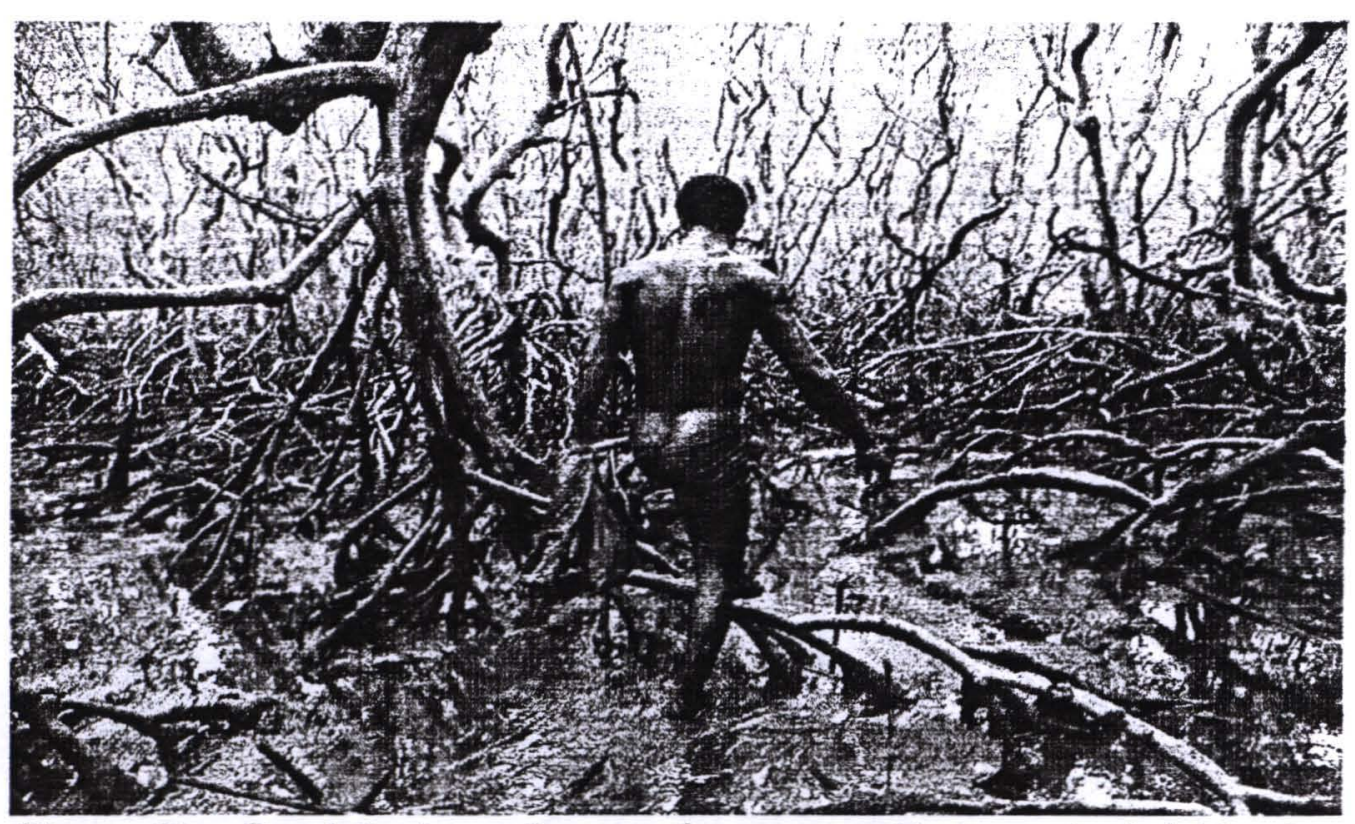

Figura 09 - Caminhada na floresta de mangue (Acervo: André Alves)

Os catadores de caranguejos do município de Vitória desenvolveram uma estratégia para amenizar o esforço na captura do caranguejo. As canoas eram amarradas nas árvores e os catadores davam cerca de três entradas no mangue. Cada entrada durava em torno de uma hora e nesse tempo eles capturavam de duas a quatro dúzias (Figura 10).

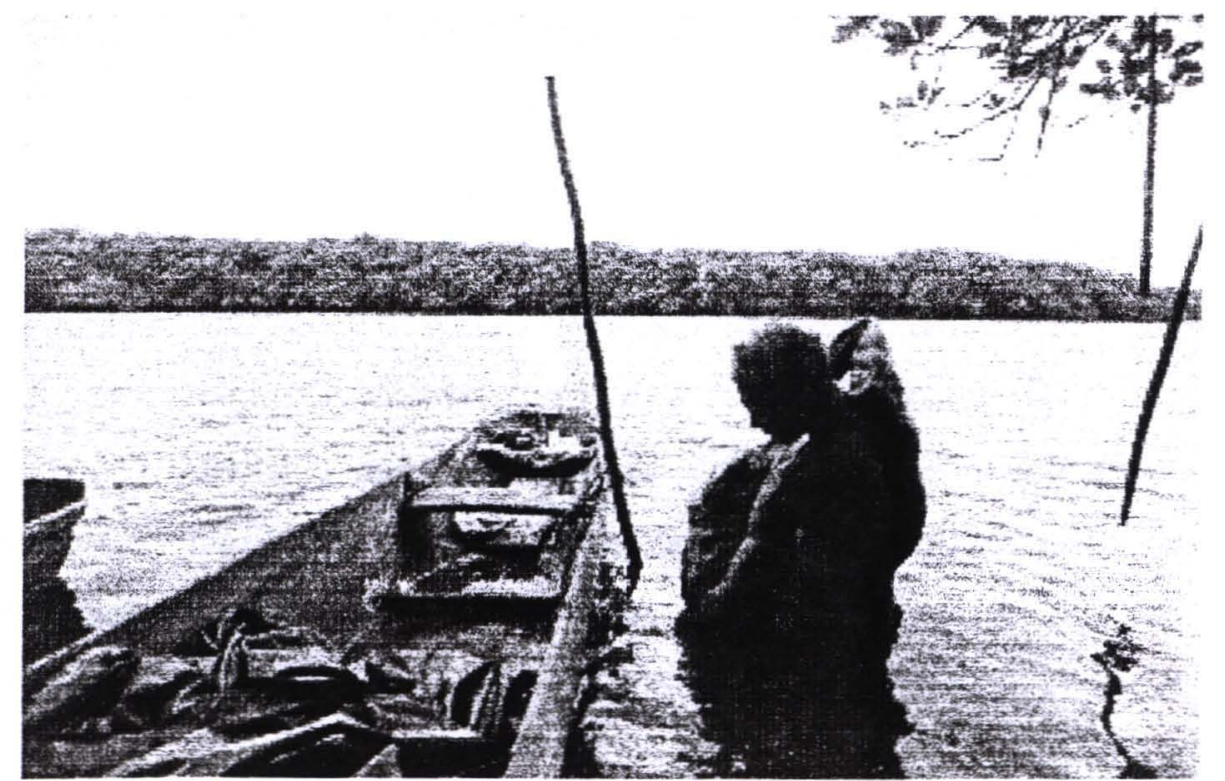

Figura 10 - Retorno para o bote após uma entrada no mangue (Acervo: André Alves) 
O esforço necessário para tirar os caranguejos do mangue e a distância percorrida durante um dia de trabalho variavam de acordo com a técnica de captura utilizada. As técnicas tradicionais (retirar caranguejo com o "braço", com o "pé", "tapando", e "com cavadeira”), embora apresentem variação entre si, exigem do catador maior esforço fisico e conhecimento sobre o ambiente (Figura 11).

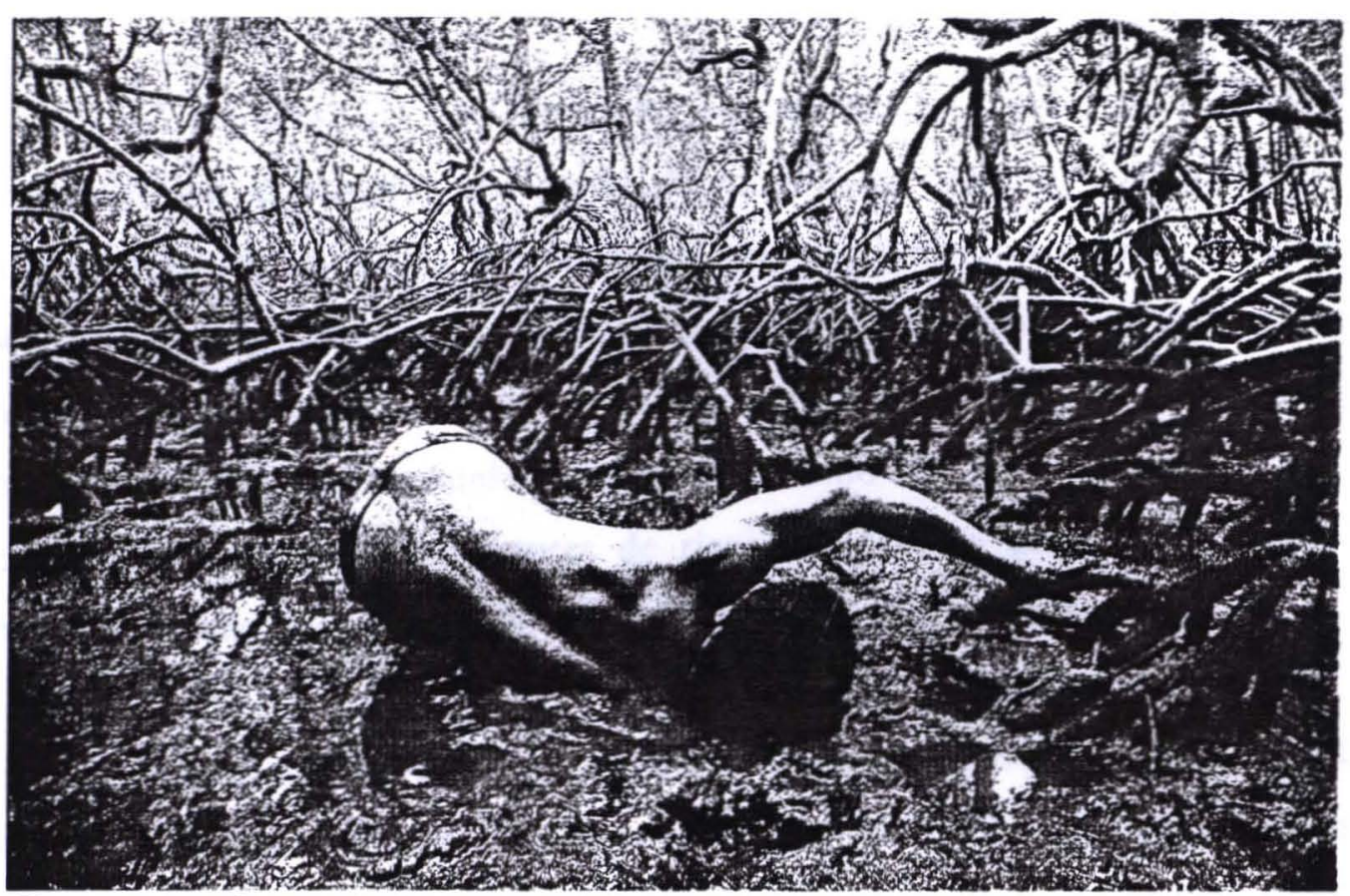

Figura 11 - Captura do caranguejo "no braço" (Acervo: André Alves)

As abordagens no campo da saúde e trabalho trouxeram contribuições sobre a distribuição das doenças nas populações como reveladora das desigualdades sociais No século XIX, Villermé, na França, analisou as taxas de mortalidade mostrando relações entre as condições de vida das classes sociais em diferentes bairros de Paris e o perfil de adoecimento desses extratos sociais. Egles, também no século XIX, fez uma descrição detalhada das condições de vida da classe operaria na Inglaterra, associando o perfil de morbi-mortalidade da população aos efeitos da industrialização naquele pais. Esses dois estudos marcaram o nascimento da epidemiologia social, embora os antigos já tivessem elaborado modelos clínicos que frisavam a importância da investigação, entre outros, dos modos de vida dos seus pacientes, a fim de compreender as suas queixas (GORNY 1991). 
Critican-se os modelos anteriores que colocam no mesmo plano o agente, 0 hospedeiro e o ambiente (quando ele é considerado), duas vias aparecem com força no cenário científico: a epidemiología social e o espaço geográfico. Essas vias surgem para "tentar integrar o biológico ao não biológico" (PAIM 1997, apud, SILVA 1985), esboçando recentemente a operacionalização da categoria espaço geográfico, nos estudos de condições de vida e saúde.

Os profissionais se deparam, freqüentemente, com as suas tentativas frustradas em estabelecer um perfil de morbidade coerente com as queixas dos trabalhadores relacionadas, por exemplo, ao desconforto ao posto de trabalho, a sensação de esgotamento ou as perturbações na vida familiar. Ou seja, o estudo da relação risco-doença é frutífero quando se trata de fatores específicos, mas grande parte dos problemas de saúde ligados ao trabalho não são específicos. Não sendo claramente associadas aos fatores de risco, as queixas geradas nas situações de hipersolicitação dos corpos e da iniciativa são pouco valorizadas.

O cenário do dia-a-dia dos catadores de caranguejos não era diferente. $\mathrm{O}$ local de trabalho era insalubre e a sensação de esgotamento físico era visível na face dos catadores, além das perturbações da vida familiar que também faziam parte do contexto diário. (Figura 12).

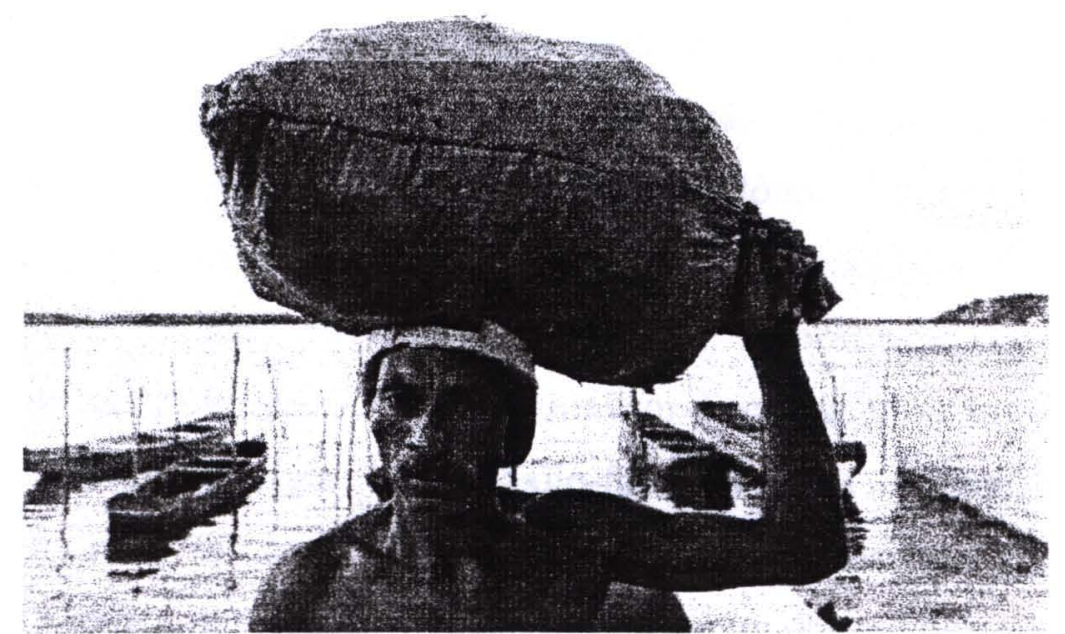

Figura 12 - Transporte dos caranguejos (Acervo: André Alves) 
A amarração do caranguejo para a comercialização era executada por uma ou duas pessoas. Os movimentos tinham que ser precisos para que não se perdesse um só caranguejo. Era uma atividade que requeria muito esforço fisico do catador de caranguejos, em função da posição incômoda e pela utilização ao mesmo tempo dos pés e das mãos (Figura 13).

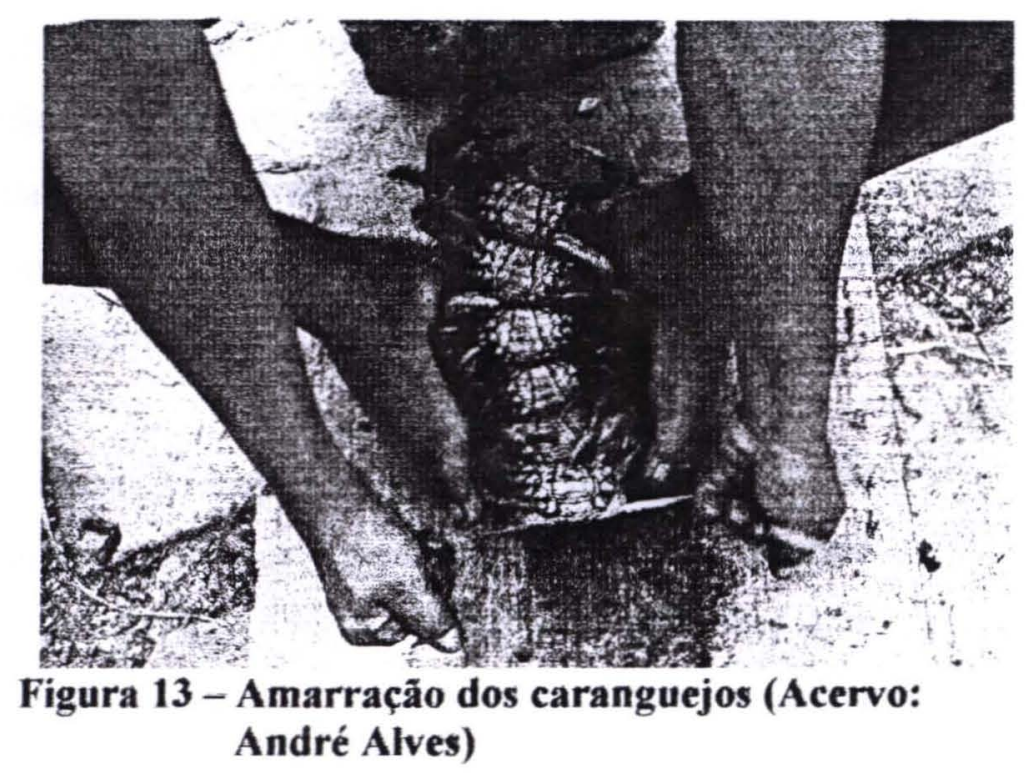

\section{Levantamento das necessidades odontológicas}

No contexto da população de estudo foi possivel verificar que o desconhecimento sobre os cuidados básicos da higiene bucal é preocupante, quando se deparam com os dados levantados de necessidades de tratamentos odontológicos. Dos 40 catadores que participaram da pesquisa, 95\% apresentaram doença periodontal; $65 \%$ necessitavam de tratamento endodôntico; $52,5 \%$ precisavam de próteses removiveis parciais ou totais; $52,5 \%$ necessitavam de reconstrução de dentes com restaurações diretas; $30 \%$ necessitavam de reconstrução de dentes com restaurações diretas e indiretas; $30 \%$ necessitavam de coroas unitarias ou ponte fixa; $30 \%$ necessitam de cirurgia buco-maxilo-facial I e II (remoção de dentes erupcionados, raizes residuais, dentes comprometidos periodontalmente, cistos, hiperplasias teciduais, infecções odontogênicas e tumores); $12,5 \%$ investigação de lesões de mucosa bucal; $5 \%$ cirurgia buco- maxilo-facial 111 (cirurgias periodontais, remoção de $3^{\circ}$ molares impactados ou inclusões erupcionados e traumatismo dento- 
alvolar) e $5 \%$ ortodontia e ortopedia (interceptação das más oclusões de origem esquelética e/ou dentária).

Em saúde bucal, a situação epidemiológica brasileira ainda é grave devido às condições sociais e econômicas da população à pequena parcela de investimentos que a área recebe em relação ao total do SUS e à falta de informação sobre os cuidados básicos de saúde. Embora a odontologia se mostre muito desenvolvida em tecnologia, não responde em níveis significativos às demandas dos problemas de saúde bucal da população. Nesse contexto, a educação em saúde bucal tem sido cada vez mais requisitada, considerando o baixo custo e as possibilidades de impacto odontológico no âmbito público e coletivo.

A saúde bucal, implícita na saúde integral, está relacionada às condições socioeconômicas e culturais da população, isto é, às condições de alimentação, moradia, trabalho, renda, meio ambiente, transporte, lazer, liberdade, acesso a serviços de saúde e à informação. Nesse sentido, a luta pela saúde bucal está, fundamentalmente, ligada à luta pela melhoria dos determinantes sociais, políticos e econômicos.

A educação e a informação sobre os cuidados com a saúde bucal são ressaltadas por diversos pesquisadores. $\mathrm{O}$ desconhecimento sobre cuidados necessários de higiene bucal representa um fator a ser considerado, uma vez que a informação, embora disponivel nas grandes mídias, não chega a todas as camadas da população da mesma forma e, dificilmente, é apreendida de modo a produzir conhecimento e autonomia em relação aos cuidados com a saúde. A importância de programas odontológicos educativos, que levantem e interpretem as necessidades das populações de menor acesso aos serviços de saúde odontológicos precisa ser valorizada.

As crises econômicas, os desajustes sociais e uma inadequação do sistema de atenção clínica e preventiva à população, figuravam entre as mais notórias razões que explicavam os contrastes observados na realidade brasileira, além do limitado acesso 
da população aos serviços disponiveis e do isolamento entre si das entidades que atuam nessa área (BRASIL 1989).

Procurando dar uma resposta correta a essa situação, a Divisão Nacional de Saúde Bucal, órgão da Divisão Nacional de Saúde Bucal, órgão da Secretaria Nacional e Coordenadoria de Supervisão e Autoria de Odontologia do Inamps elaboraram, em 1989, a Política Nacional de Saúde Bucal. As prioridades dessa política são definidas segundo os grupos populacionais, tipos de serviços, danos, recursos humanos, modalidades de organização e financiamento do setor (BRASIL 1989).

O texto constitucional que formula o Sistema Único de Saúde (SUS), sua regulamentação, e outros textos normativos constituem as bases legais para as ações de saúde bucal no SUS, propondo seguir os mesmos princípios que regem a dimensão macro da saúde, ou seja, um direito básico acessível a todos os cidadãos, pautado na universalidade, na eqüidade, na integralidade, compondo um sistema descentralizado, hierarquizado em diferentes níveis de complexidade, e que esteja regulado através do controle social (SILVEIRA F 2002).

As políticas de saúde bucal do SUS buscam favorecer a transformação da prática odontológica por meio da incorporação de pessoal auxiliar, novas tecnologias e ações coletivas de saúde, visando alterar suas características epidemiológicas e obter impacto na cobertura da população e na construção da cidadania. Para atingir essas metas, é imprescindivel criar e incentivar práticas comunitárias que possibilitem o crescimento da consciência sanitária e a mobilização da sociedade civil em torno das questões de saúde.

Apesar de as conquistas do movimento sanitário brasileiro terem sido consolidadas parcialmente na atual Constituição, na prática, essas conquistas não têm sido concretizadas em melhoria da qualidade de vida da população brasileira. No Brasil, um dos desafios que se coloca para a prática profissional da odontologia (produção do conhecimento, produção de serviços e desenvolvimento de recursos 
humanos) está baseado no relacionamento de uma atuação responsável na luta pela conquista dos objetivos que incluem a liberdade, os direitos e deveres individuais e coletivos, tendo em vista alcançar a máxima plenitude de qualidade de vida (BRASIL 1993).

Dentro desse modelo, também, PINTO (2000), observou que aproximadamente $2 / 3$ dos trabalhadores não tinham no Brasil condições reais de serem atendidos em clínicas privadas, nas quais se concentravam $3 / 4$ do tempo de trabalho ofertado pelos cirurgiões-dentistas.

São propostas que visam à maior aproximação com os determinantes do processo saúde-doença bucal, considerando as políticas econômicas e sociais, especialmente as de saúde e educação, e manifestam implícita vinculação a projetos sociais em que a saúde tem relevância pública, com prioridade pelo Estado e pela sociedade (NARVAI 1994)

Propostas com o foco no coletivo ainda representam um desafio ao campo da odontologia, tanto pelo fato de a formação na área dirigir-se para o individual, quanto pelo fato de apenas uma pequena parte do investimento feito em ciência e tecnologia dirigir-se aos problemas de saúde bucal com relevância para a saúde publica.

Nesse contexto, a educação em saúde, como prática social voltada para o coletivo, representa uma importante possibilidade de ampliar a atuação das práticas de promoção de saúde bucal no espaço público. SOARES (1988), refere que muitas medidas preventivas permitem combater a cárie e a doença periodontal. A higiene bucal, fluoração e alimentação não-cariogênica constituem medidas eficazes para fazer frente aos problemas bucais. Mas, para que tenham êxito, precisam fundamentar-se em programas educativos. 


\section{Avaliação audiométrica}

Neste estudo foram obtidos os seguintes dados: 33 catadores, ou seja, 82,5\% da população não apresentaram alteração digna de comentário, 3 catadores $(7,5 \%)$ apresentaram uma perda auditiva significante e os demais 5 catadores $(12,5 \%)$ apresentaram uma intercorrência e foram encaminhados para um especialista (Policlínica do Bairro São Pedro, próximo a FAESA) para retirada de cerume, e posterior retorno para a realização da audiometria.

Alguns ambientes de trabalho possuem uma série de agentes físicos e químicos que, combinados com extressores psicossociais e organizacionais, podem representar efeitos à saúde dos expostos. Estudos sobre ambientes de trabalho relataram que nas indústrias podem ser encontradas até nove agentes nocivos simultâneos, com uma média de 2,7 agentes (RENTZSCH 1992).

Levando em consideração apenas os agentes químicos, o número de agentes usados e de combinações possíveis é substancial. Propriedades tóxicas foram identificadas para pelo menos três classes de produtos químicos industriais: metais, solventes e asfixiantes (FECHTER 1989; HAIDER 1990; JOHNSON 1994; RYBAK 1992).

É possível afirmar que se a exposição a estes produtos atingir altos níveis, esta poderá representar um risco à audição, mesmo se não houver exposição a níveis excessivos de ruídos, como sugerido por vários autores (ATSDR 1993; BARREGARD 1984; BENCKO 1977; DISCALZI 1992; DISCALZI 1993; JACOBSEN 1993).

MORATA (1990), estudou os efeitos da exposição simultânea a ruído e tolueno (solvente aromático) sobre a audição e equilibrio de trabalhadores. Os resultados dessa investigação sugerem que a exposição a altas concentrações de tolueno num ambiente ruidoso pode aumentar de maneira significativa o risco de 
adquirir uma deficiência auditiva ocupacional e que o ruído ocupacional não pode mais ser considerado como a única ameaça á audição dos trabalhadores.

SOUZA (1994), analisou do ponto de vista preventivo, os efeitos auditivos provocados pela interação entre ruido e solvente, fatores reconhecidamente nocivos nos ambientes de trabalho.

Os solventes podem afetar a audição por meio da lesão provocada no Sistema Nervoso Central e Periférico, pois quando é absorvido pelo organismo tende a ligarse a outros lipídios. Os estudos sobre interação de fatores nocivos, especialmente ruídos e solventes, têm-se desenvolvido signitivamente, embora ainda não exista consenso sobre essa questão.

As pesquisas citadas, demonstram a importância da continuidade de estudos na área, principalmente no sentido de desenvolver um programa de controle que previna a ocorrência de perdas auditivas em trabalhadores expostos a produtos químicos.

Os catadores de caranguejos utilizavam o óleo diesel (solvente) como repelente aos maruins e as mutucas, insetos encontrados em grande quantidade no manguezal, para se defender de sua picada que é bastante dolorida. $\mathrm{O}$ transporte do óleo era feito em frascos plásticos normalmente amarrados a cintura (Figura 14). 


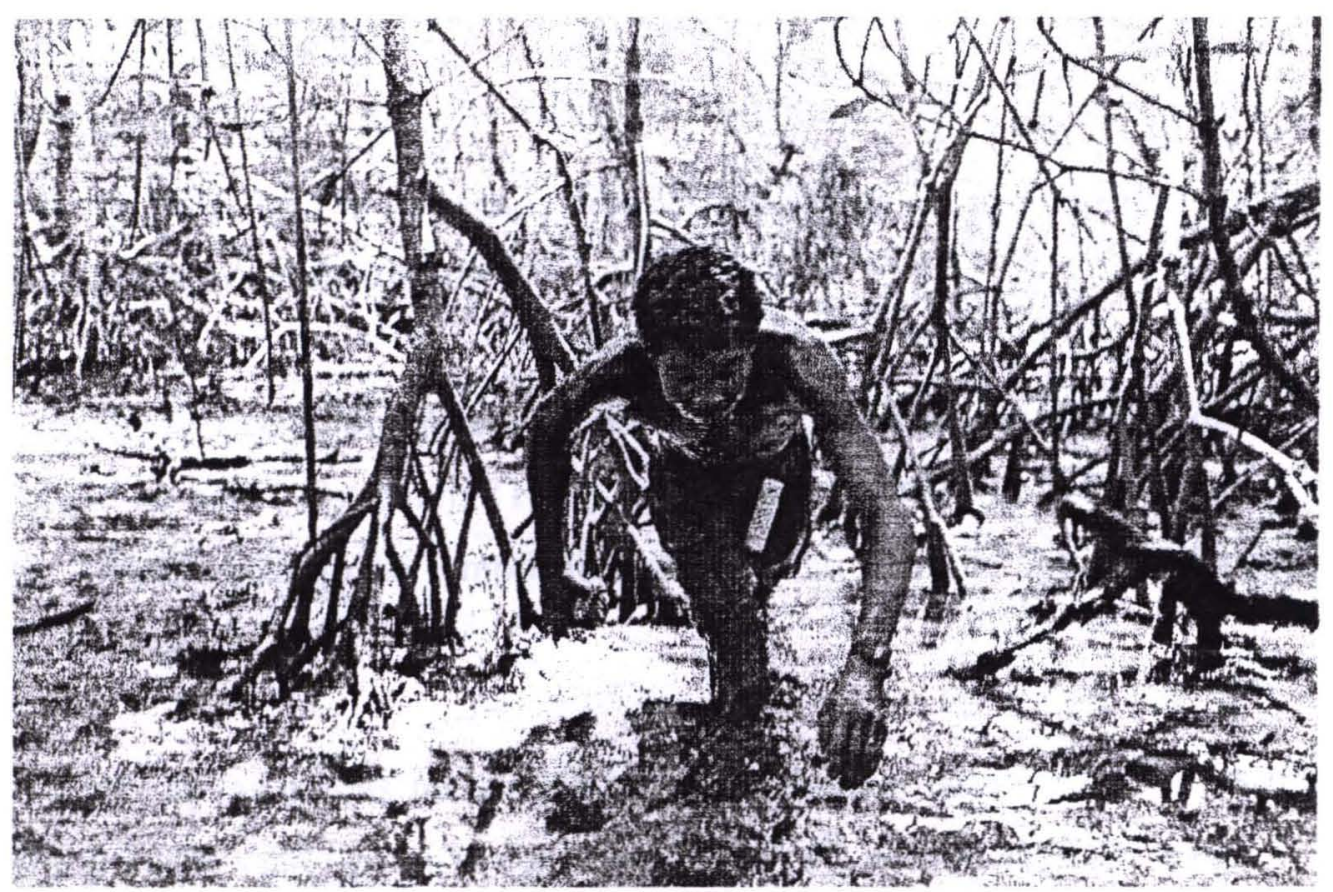

Figura 14 - Catador com o frasco para transporte do b́leo diesel amarrado à cintura (arquivo André Alves).

Visando analisar os efeitos da exposição simultânea a ruído e a óleo diesel sobre a saúde dos catadores, foram realizadas entrevistas, testes audiométricos e vestibulares na população de estudo. 


\section{CONCLUSÕES}

A presente investigação, com catadores de caranguejos do município de Vitória, permitiu concluir que:

Tratava-se de um grupo composto exclusivamente por homens que residiam no bairro Estrelinha (16\%) seguido dos bairros Maria Ortiz (15\%) e Jabour com $15 \%$.Em relação ao tempo de residência no local de estudo $38 \%$ estavam no local há 44 anos.

As faixas etárias mais significativas de catadores foram entre 28 e 38 anos, ( $38 \%$ do total) sendo este o grupo responsável pela perpetuação da cultura do catador de caranguejo. Eram também os que detiam a experiência, "o saber popular" e, portanto, sob este aspecto podem ser considerados como a "população tradicional dos manguezais".

Cinqüenta e oito porcento dos entrevistados são solteiros, $42 \%(32 \%+6 \%+$ $2 \%$ ) são casados, separados ou viúvos. A relação entre os casais costuma ser informal.

Em relação às condições de trabalho das esposas/companheiras, verificou-se que $26 \%$ estavam trabalhando como doméstica, faxineira, atendente de cantina e desfiadeira de crustáceos e mariscos. $\mathrm{O}$ trabalho no mangue é predominantemente executado por homens $\mathrm{e}$ as mulheres são consideradas como auxiliares. Os dados levantados a respeito do número de filhos demonstraram uma grande mudança na formação das familias quando comparados com estudos anteriores. A maioria das famílias é composta por até seis filhos.

Quanto ao grau de escolaridade, o grupo revelou-se homogêneo, 90\% dos catadores entrevistados freqüentaram a escola, sendo que $62 \%$ possuem o $1^{\circ}$ grau incompleto. Dos catadores que declararam ter feito o $2^{\circ}$ grau completo, a maioria não conseguiu inserção no mercado de trabalho remunerado, conseqüência do 
descaso do ensino público. O nível de instrução é baixo, reproduzindo, uma característica da classe, como nas demais regiões brasileiras.

A maioria dos entrevistados, 55\% residiam em casas próprias, o que lhes conferia relativa estabilidade. As construções eram de alvenaria e o padrão das residências vem se modernizando, configurando as alterações culturais em processos.

A renda média obtida pelos catadores variava entre um e cinco salários mínimos, sendo que $56 \%$ recebiam entre um e dois salários mínimos.

Embora a associação dos catadores de caranguejos tivesse o reconhecimento da maioria, como entidade agregada da classe, os conflitos e interferências de ordem política dificultavam o processo de organização social da classe, impedindo o fortalecimento da instituição como sua representante legal, capaz de encaminhar as lutas da classe.

Em relação aos aspectos ambientais, os catadores de caranguejos percebiam os processos de interferência da comunidade de catadores sobre o meio físico natural, o manguezal, e a exploração de seus recursos.

Neste estudo, pode-se, portanto, concluir que os catadores de caranguejo que atuaram por longos anos no espaço do manguezal, conseguiram estabelecer um grande vínculo com a área e manter com o ecossistema uma relação que extrapola a questão de subsistência. Registrou-se catadores com até 40 anos de trabalho no mangue. Entre os entrevistados predominava a idéia da importância da proteção do ecossistema como fonte de recursos.

Do total dos catadores de caranguejos que participaram da pesquisa, somente $40(40 \%)$ compareceram para a realização da anamnese, levantamento e fichamento dos dados sobre a sua saúde. Verificou-se que existe uma resistência cultural por parte dos catadores em relação à prevenção da saúde, que talvez esteja relacionada na abordagem inadequada que muitas vezes tem sido utilizada nos serviços de saúde 
Em relação aos hábitos de vida, $47,5 \%$ dos participantes fumavam regularmente e $87,5 \%$ afirmaram beber socialmente. Os dados são preocupantes, pois além de trabalharem em local insalubre, têm seus problemas respiratórios agravados pelo fumo. A bebida alcoólica (cachaça) é ingerida diariamente, faz parte do "arsenal de trabalho" para espantar o frio das águas do mangue. Provavelmente, a maioria das desavenças entre familiares é decorrente do uso da bebida alcoólica.

Grande parte das queixas verificadas durante a avaliação física (dores de coluna, nos rins, nas varizes, câimbra, insônia, estresse, na cabeça, no tórax, nos braços, no quadril, nos ombros e mãos inchadas) estavam diretamente relacionadas com o esforço despendido na locomoção, captura e transporte dos caranguejos dentro do manguezal.

Em relação ao levantamento do diagnóstico odontológico, 95\% apresentaram doença periodontal, estes dados foram justificados pelo grande desconhecimento sobre os cuidados básicos da higiene bucal pela população de estudo. A utilização de técnicas preventivas para a promoção de saúde individual e coletiva, utilizando recursos epidemiológicos relacionados à doença periodontal, ao prognóstico, ao plano de tratamento, à terapêutica aplicada, à reavaliação periodontal, à terapia básica e aos tratamentos cirúrgicos, provavelmente, possibilitarão melhores condições de saúde bucal para os catadores.

Dos que sesubmeteram ao exame audiométrico 3, (7,5\%) apresentaram uma perda auditiva significante que pode estar associada à utilização de óleo diesel (solvente) no corpo para se defender das mutucas e do frio.

A atividade de coleta do caranguejo, exercida de forma inconseqüente, gera prejuízos a toda comunidade de catadores de caranguejos. Notou-se que falta ao grupo um pouco de organização, espirito de coletividade, com força para intervir em beneficio próprio, impedindo o privilégio para alguns. Existe uma tendência crescente de pessoas envolvidas com a coleta do caranguejo. Vale ressaltar a relevância do trabalho em equipe, na medida em que os conhecimentos são 
enriquecidos pelo de outros e é geralmente no grupo que o indivíduo toma consciência do trabalho coletivo, o que contribui para compreensão da essência da ação democrática.

A maioria, (82\%) dos catadores de caranguejos entrevistados, afirmou que a fiscalização do governo na área do manguezal tem sido efetiva, pois os fiscais estão mais atentos aos problemas do mangue, o controle está mais eficaz e conseqüentemente o ambiente do mangue tem melhorado para as comunidades que vivem dele.

Em relação às mudanças percebidas pelos catadores referentes à cata do caranguejo, constatou-se a diminuição das áreas de mangue, o aumento do número de pessoas sobrevivendo da captura dos caranguejos e a utilização da redinha, classificada pelos próprios catadores de caranguejo como predatória. Constatou-se que o conjunto dessas mudanças acarretou o declínio da quantidade de caranguejos existentes nos manguezais de Vitória.Entre os entrevistados, $40 \%$ perceberam diferença na qualidade da água da baía de Vitória, enquanto $60 \%$ relataram não sentir nenhuma diferença. No entanto, o problema levantado pelos catadores foi em relação ao lixo que é depositado pelos próprios moradores, aumentando a poluição da água.

Em resumo, a cata do caranguejo enquanto atividade de subsistência econômica, no manguezal é uma atividade geradora de renda expressiva para os caranguejeiros. Constatou-se que a maioria dos catadores de caranguejos vivia exclusivamente da cata do caranguejo-uçá, ou seja, retirava sua subsistência e a da familia da captura desse crustáceo.

Concluiu-se que os catadores de caranguejos detinham a compreensão de que a solução para os problemas ambientais exige a participação de todos, incluindo os usuários dos recursos, embora entendam ser de responsabilidade do governo promover ações de natureza assistencialista e de fiscalização. 
O contato com os diversos problemas ambientais do entorno do manguezal parece que motivou os catadores para o exercício criativo de buscar soluções para os problemas ambientais que interferem na qualidade de vida dos catadores.

Buscou-se com a pesquisa causar implicações sociais, politicas e culturais na consolidação do grupo participante de catadores de caranguejos e na mudança de percepção de seus membros, em torno de suas práticas cotidianas. Mudanças essas que foram percebidas no decorrer da pesquisa, como a promoção de saúde e a organização do grupo em busca de soluções para os problemas referentes à legalização da profissão. 


\section{CONSIDERAÇÕES FINAIS}

Como observou AYRES (2002), em estudo crítico sobre as práticas educativas no âmbito das doenças sexualmente transmissíveis, especialmente do HIV/Aids, as estratégias educativas em saúde ainda não passam da superficie do problema, observando que, mais uma vez, precisamos recorrer às teorias de Paulo Freire para avançar no trabalho educativo, abrindo espaço para a discussão dos temas de saúde e não apenas transmitir informação. É preciso ultrapassar o paradigma comportamentalista, ancorado na abordagem higienista e individualista da prevenção para construir métodos mais dialógicos e construtivistas, que substituam a atitude normativa e modeladora de comportamento pela atitude emancipatória, valorizando a interação entre pares, a reflexão, o protagonismo dos alunos e a busca de parcerias (escola, universidade, serviços de saúde, ONGs) para viabilizar a continuidade dos programas implantados.

Grande parte das opiniões dos catadores de caranguejos, baseadas na simples experiência de trabalho no mangue, coincide com informações geradas, a partir de estudos cientificos, o que confirma a importância de se investir na preservação e no resgate da cultura deste grupo, detentores de uma sabedoria empírica, que pode se constituir num importante elo do conhecimento humano.

Um Programa de Educação Ambiental para as comunidades pesquisadas, elaborado a partir dos indicadores identificados pelo estudo, poderá favorecer a implementação de ações coletivas, mobilizando as comunidades de catadores de caranguejos da região, sociedade civil organizada e Poder Público, agindo como ferramenta de orientação, apoio e integração das partes, constituindo-se numa providência de fundamental importância, na viabilização de propostas de gestão compartilhada, com vistas à gestão ambiental dos ecossistemas costeiros. 
A Educação Ambiental influencia a percepção ambiental, na medida em que procura elucidar e interpretar as preocupações e os valores éticos e econômicos dos indivíduos e da coletividade, intervenientes na relação societária.

Outra questão a se considerar é que para a eficácia de qualquer programa de Educação Ambiental, os aspectos efetivos da aprendizagem também devem ser priorizados. A Educação Ambiental não se reduz à transmissão de conceitos ecológicos, trabalha $\mathrm{o}$ aspecto emocional do desenvolvimento do educando, ajudando-o a esclarecer e a expressar as suas impressões e os valores pelos quais Orealiza a sua interpretação do meio que o envolve.

A avaliação das modificações necessárias no ambiente de trabalho e a seleção das medidas preventivas a serem tomadas, deveria, obrigatoriamente, contar com a participação dos catadores de caranguejos, que são os maiores interessados na conservação de sua saúde física e psíquica. 


\section{RECOMENDAÇÕES}

Em função do baixo nível de escolaridade, sugere-se a inclusão dos catadores de caranguejos no projeto São Pedro na Ponta do Lápis, resultando na melhoria da qualidade de vida dessa comunidade.

A análise de estudos anteriores e a pesquisa realizada demonstram importância da continuidade de estudos na área, principalmente, no sentido de desenvolver um programa de controle que previna a ocorrência de perdas auditivas em trabalhadores expostos a solventes. A autora sugere que estudos similares ao que foi realizado sejam desenvolvidos junto ao restante do grupo de catadores de caranguejos, a fim de conhecer melhor as perdas auditivas de origem profissional (na cata de caranguejo de manguezais) e contribuir para a implementação de medidas de saúde e de segurança necessárias no desenvolvimento das atividades no mangue.

Pela ausência de conhecimento em relação a contaminação do meio ambiente pelas tintas anti-incrustantes, utilizadas para a pintura das embarcações, pelo mercúrio há a necessidade da criação de um Programa de Educação Ambiental na região que opere junto ao grupo de catadores, com o objetivo de sensibilizá-lo quanto ao risco da manutenção dessas atividades sem o correto procedimento de recolhimento dos resíduos e seu depósito em local apropriado.

Os prejuízos sociais resultantes do consumo de álcool, como gastos com tratamento das dependências e suas complicações, horas de trabalho perdidas, evasão escolar e criminalidade, constatados na população de estudo, levam a sugerir que a pesquisa possa ser aprofundada e que os participantes e seus familiares passem a usufruir de acompanhamento psicológico.

Entre os alimentos consumidos pelos catadores de caranguejos, praticamente não foi citado a carne de caranguejo, fonte de proteina de alta qualidade, utilizada quase que exclusivamente como valor de troca. Sugere-se que essa comunidade possa ser incluída nos projetos do curso de nutrição, para que possam ser orientados 
em relação à alimentação com o objetivo de lhes proporcionar uma melhor qualidade de vida. 


\section{REFERÊNCIAS}

Agneu R. The individual and adaptative process. Sociological Quaterly. 1981. p. 105-117.

Alcântara Filho P de. Biologia e ecologia do caranguejo-uça, Ucides Cordatus (Linnaeus, 1769) (Crustácea Decápoda - Brachyura), no manguezal do rio Ceará (Brasil). São Paulo; 1978. [Dissertação de Mestrado Instituto Oceanográfico da Universidade de São Paulo].

Almeida F. Negócios. In: Trigueiro A, coordenador. Meio Ambiente no Século 21: 21 especialistas falam da questão ambiental nas suas áreas de conhecimento. Rio de Janeiro: Sextante; 2003. p. 123-142.

Alves A. Os Argonautas do Mangue. Campinas (SP): Editora Unicamp; 2004.

Anchieta V. de. Cartas - correspondência ativa e passiva (1554 - 1596): XI cartas sobre as coisas naturais de São Vicente (1560). São Paulo: Loyola; 1984. p. 121-143.

Andrade J de. Folclore na Região do Salgado, Pará: teredos na alimentação profissões ribeirinhas. $2^{\mathrm{a}}$ ed. São Paulo: Escola de Folclore; 1984.

Andrade MC de. Geografia econômica do Nordeste. $2^{a}$ ed. São Paulo: Atlas S.A; 1974.

Andreatta G. Na lama prometida à redenção. São Paulo: O recado; 1987.

Araújo DSD de, Maciel NC. Os manguezais do recôncavo da baía de guanabara. Caderno FEEMA 1979; (10): 1-113. 
Assunção AA. De la déficience à la gestion collective du travial: lês troubles músculo-squelettiques dans la restauration collective. Paris; 1998. [Tese de doutorado em ergonomia - EcolePratique dês hautes Etudes].

ATSDR, Agency for Toxic Substances and Disease registry/ division of health studies. National Exposure Registry-Trichloroethylene (TCE) SubregistryBaseline Technical Report - 1993. Washington DC: U S Department of Health and Human Services; 1993.

Aveline LC. A fauna dos manguezais brasileiros. Revista brasileira de Geografia. $1980 ; 42$ (4): 786-821.

Ayres JRCM. Práticas educativas e prevenção de HIV/Aids: lições aprendidas e desafios atuais. Interface - Comunicação Saúde, Educação. 2002; 6 (1): 63-72.

Barbieri E. Desenvolver ou preservar o ambiente?. São Paulo: Cidade Nova; 1996.

Barbieri JC, LAGE AC. Avaliação de Projetos para o Desenvolvimento Sustentável: Uma análise do Projeto de Energia Eólica do Estado do Ceará com base nas dimensões da sustentabilidade. Federação das Indústrias do Estado do Ceará - FIEC [página online] 2001. Disponível em: «URL: http://www.sfiec.org.br/artigos» [2003 mar 15].

Barregard L, Axelsson A. Is there na ototraumatic interactionbetween noise and solvents? Scand Audiol; 1984.

Begossi A. Linguagem, conhecimento e mudança social: alguns aspectos ecológicos. In: Encontro de Ciências Sociais e o Mar, 3º, 1989, São Paulo. Anais. São Paulo: Programa de Pesquisa e Conservação de Áreas Úmidas no Brasil, IOUSP, F. FORD, UICN, 1989. p.322, p. 247-251. 
Begossi A. Os pescadores e intermediários da Ilha de Búzios: Laços familiares e modelos de produção. Journal of the Brazilian Association for the Advancement of Science. 1996; 48 (3): 141-147.

Besserman S, indicadores. In: Trigueiro A, coordenador. Meio Ambiente no Século 21: 21 especialistas falam da questão ambiental nas suas áreas de conhecimento. Rio de Janeiro: Sextante; 2003. p. 91-106.

Bencko V, Symon K. Test of environmental exposure to arsenic and hearing changes in exposed children. Environ Health Perspect. 1977;19: 95-101.

Bonduki N. Habitat - As práticas bem-sucedidas em habitação, meio ambiente e gestão urbana nas cidades brasileiras. São Paulo: Studo Nobel; 1996.

Borgo IA. UFES 40 anos de historia. Vitória: Lastro; 1995

Brasil.Constituição 1988; Constituição da República Federativa do Brasil. São Paulo; IMESC; 1988.

Brasil. Lei n. 7661, de 16 de maio de 1988. Define a Zona Costeira. Plano Nacional de Gerenciamento Costeiro, Brasília.

Brasil. Lei n. 6.938/81, de 21 de novembro de 1990. Instituiu a Política Nacional do meio Ambiente. Plano Nacional de Gerenciamento Costeiro, Brasilia.

Brasil. art $225 \S 4^{\circ}$. Considera a Zona Costeira como Patrimônio Nacional. Plano Nacional de Gerenciamento Costeiro, Brasília.

Brasil. art 511. Lei do Trabalho - CLT. 
Brasil. Política Nacional de Saúde Bucal. Divisão Nacional de Saúde Bucal. [página online] 1989; Disponível em: «URL:http://dr2001.saude.gov.br/sps/areastecnicas/bucal/ publicacoes/». [24 de Outubro de 2002].

Brasil. Ministério da Saúde. Secretaria Nacional de Programas Especiais de Saúde. I Conferência Nacional de Saúde Bucal Relatório Final [página online] 1993; Disponível em: «URL:http:/drt2001.saude.gov.br/sps/areastecnicas/bucal/publicacoes/publicacoe s/.htm».[ 24 de Outubro de 2002].

Capra F. Educação. In: Trigueiro A, coordenador. Meio Ambiente no Século 21: 21 especialistas falam da questão ambiental nas suas áreas de conhecimento. Rio de Janeiro: Sextante; 2003. p.19-34.

Cardim F. Tratados da terra e gente do Brasil. São Paulo: Itatiaia/ EDUSP; 1980

Carmo TMS e col. Os Manguezais da baía de Vitória, Espírito Santo: um ecossistema ameaçado. Revista Brasileira de Biologia. 1995; 4: 801-818.

Carmo TMS do. Os manguezais ao norte da baía de Vitória (ES). In: Simpósio sobre Ecossistemas da Costa Sul e Sudeste Brasileira; 1987; Cananéia, (SP). São Paulo: Síntese dos Conhecimentos, Academia de Ciências do Estado de São Paulo; 1987. p. 173 - 194.

Carrera CJ. Efectos históricos de la interacción entre los sistemas sócioeconômicos y los manglares: el caso de Puerto Rico. In: Simpósio Latinoamericano sobre oceanografia Biológica; 1975; Venezuela. Venezuela: Memórias; 1977. p. 151-161. 
Cascaes F. A pesca da tainha na ilha de Santa Catarina. Florianópolis: Museu de Antropologia, Universidade Federal de Santa Catarina; 1978.

Castells M. A sociedade em rede: a era da informação: economia, sociedade e cultura. São Paulo: Paz e Terra; 1999. v.1.

Castro V de. Homens e Caranguejos. São Paulo: Brasiliense; 1983.

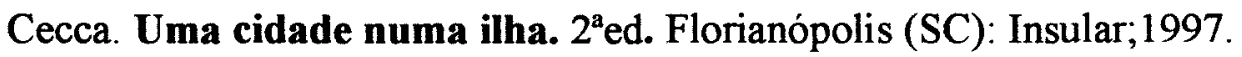

Clark CW. Mathematical Bioeconomics: the optimal management of renewable resources. New York: Wiley; 1990.

Clay JW. Parks and people in cultural survival quaterly. 1985; 9 (1).

Comissão Mundial para meio ambiente e desenvolvimento. Nosso futuro comum. Rio de Janeiro (RJ), Fundação Getúlio Vargas, 1991.

Costa S. Uma Cidade Ocupada. Revista Espírito Santo Agora. Setembro de 1981.

Crespo S, Novags E. O que o brasileiro pensa do meio ambiente e do consumo sustentável. Revista Eco 21. 2002; 63: 29-40.

Crespo S. Opinião Pública. In: Trigueiro A, coordenador. Meio Ambiente no Século 21: 21 especialistas falam da questão ambiental nas suas áreas de conhecimento. Rio de Janeiro: Sextante; 2003. p. 59-74.

Cunha LH de O. Espaço e territorialidade no universo da pesca artesanal. In: Anais do $3^{\circ}$ Encontro de Ciências Sociais e o Mar; 1989; São Paulo. São Paulo: Programa de Pesquisa e Conservação de áreas úmidas no Brasil, IOUSP/F. FORD, UICN; 1989. 
Daniellou F, Laville A e Teiger C. Ficção e realidade do trabalho operário. Revista Brasileira de Saúde Ocupacional. 1989; 17 (68):7-13.

Del Rio e Oliveira, organizadores. Percepção Ambiental: A experiência brasileira. São Carlos (SP) Universidade Federal de São Carlos: Studio Nobel; 1998.

Dias GF. Os quinze anos da Educação Ambiental no Brasil. In: Em aberto. 1991; 10 (49): 3 - 14.

Dias GF. Educação Ambiental princípios e práticas. $6^{\mathrm{a}}$ ed. São Paulo: Gaia; 2000.

Dias GF, Tavares A. São Pedro 6. Vitória: Secretaria Municipal de Vitória; 2001.

Diegues AC. Pescadores camponeses e trabalhadores do Mar. São Paulo: Ática; 1983.

Diegues AC. Conservação e Desenvolvimento sustentado de ecossistemas litorâneos no Brasil. In: Simpósio Ecoss. Sul-Sudeste brasileira. ACIEP, 3; 1987. p. 196-143.

Diegues AC, Sales RS, editores. Coletânia de trabalhos apresentados no II Encontro de Ciências Sociais e o Mar no Brasil. São Paulo: IOUSP/F. FORD/ UICN; 1988.

Diegues AC. Comunidades litorâneas e os manguezais no Brasil. In: Simpósio sobre Ecossistemas da costa Sul e Sudeste Brasileiro; 1990; Águas Lindóia, (SP). São Paulo: Academia de Ciências do Estado de São Paulo; 1990. p.124146. 
Diegues AC. Ilhas e mares: simbolismo e imaginário. São Paulo: Série Geografia: teoria e realidade $n^{\circ}$ 44. São Paulo: Editorial Hucitec; 1998. p. 272.

Discalzi GL, Capellaro F, Bottalo L, Fabbro D, Mocellini A. Auditory brainstem evoked potentials (BAEPs) in lead-exposed workers. Neurotoxicol; 1992.

Discalzi G, Fabbro D, Meliga F, Mocellini A, Capellaro F. Effects of occupational exposure to mercury and lead on brainstem auditory evoked potentials. Int J Psychophysiol; 1993.

Fechter LD. A mechanistic basis for interactions between noise and chenical exposure, Arch complex Environ Studies. 1989; 1(1): 15-22.

Feldmann F. Consumismo. In: Trigueiro A, coordenador. Meio Ambiente no Século 21: 21 especialistas falam da questão ambiental nas suas áreas de conhecimento. Rio de Janeiro: Sextante; 2003. p. 143-158.

Ferreira RD. Os Manguezais da baía de Vitória (ES). Um estudo de geografia física integrada. Vitória (ES). São Paulo; 1989. [Tese de Doutorado Universidade de São Paulo].

Forman S. The raft fisherman. Ed. Bloomington \& London: Indiana University Press; 1970.

Gadgil M, Berkes F, Folke C. Indigenous Knowledge for biodiversity conservation. Ambio; 1993. p. 151-156.

Garcia AA. Diagnóstico ambiental da Lagoa da Conceição e do Canal da Barra através de indicadores físico-químicos dos sedimentos de fundo e dos indicadores sócio-ambientais. Florianópolis (SC); 1999. [Dissertação de 
mestrado apresentada ao Programa de Pós-Graduação em Engenharia Ambiental da Universidade Federal de Santa Catarina - UFSC.]

Gil AC. Técnicas de pesquisa em economia e elaboração de monografias. $3^{\text {a }}$.ed. São Paulo: Atlas; 2000.

Godelier M.Territory and property in primitive society. Soc. Sci. Inf. 1978;17(3): 399-426.

Gordon HS. The economic theory of a common propperty resource: the fisery. Journal Political Economy; 1954. 124-142.

Gorny P. L'aventure de la médicine. Lattès, Paris; 1991.

Gouveia N. Saúde e Meio Ambiente nas cidades: os desafios da saúde ambiental. Saúde e Sociedade. 1999; 8 (1): p.49-61.

Haider M, Kundi M, Groll-Knapp, Koller M. Interactions between noise and air pollution. Environ Intern, 1990; 16: 593-601.

Hill AF. Economic Botany. $2^{\circ}$ ed. New Delhi: Mc Graw-Hill; 1974.

Ito LM e col. Terapia cognitivo-comportamental para transtornos psiquiátricos. Porto Alegre: Artmed; 1998.

Jacobsen P, Hein HO, Suadicani P, Parving A, Gyntelberg F. Mixed solvent exposure and hearing impairment: an epidemiological study of $3284 \mathrm{men}$. The Copenhagen male study. J Occup. 1993; Med 43 (4): 180-184.

Johnson AC. The ototoxic effect of toluene and the influence of noise, acetylsalicylic acid or genotype. A study in rats and mice. Scand Audiol Suppl. 1994; 39: 1-40. 
Kater KV, Kater MGL. As pescadeiras de crustáceos e o problema dos manguezais dos municípios de Igarassu e Itapissuma, em Pernambuco. In: Encontro Nacional de Estudos Sobre o Meio Ambiente; 1991; Londrina, (PR). Londrina: Comunicações UEL/NEMA; 1991. p.198-206.

Lago MC de S. Modos de vida e identidade: "Sujeitos no processo de urbanização da Itha de Santa Catarina". Florianópolis: Editora da Universidade federal de Santa Catarina; 1996.

Lima MJA . Ecologia Humana Realidade e Pesquisa. Petrópolis: Vozes; 1984.

Lucena M. Paraiba-os homens do caranguejo. Revista Horizonte Geográfico, 1991; 18: 28-36.

Luerderwaldt H. Os Manguezais de Santos. Revista do Museu Paulista, 1919; 11: 309-408.

Machado GEM. A pesca tradicional em Marica (RJ) sob uma Perspectiva de Ecologia Cultural. São Paulo; 1995. [Tese de Doutorado do Programa de PósGraduação em Ecologia e Recursos Naturais da Universidade Federal de São Carlos.]

Machado PAL. Direito Ambiental Brasileiro. Malheiros Editoras; 1992.

Maldonado, SC. Pescadores do mar. São Paulo, Ática S/A, 1986. p.75.

Marconi EM e Lakatos MA de. Metodologia científica. São Paulo: Atlas; 1996.

Marius C e col. Les sols de mangrove de la baia de Vitória (Brésil). Paris: Copédith; 1987. v. 23. 
Mello JAG. Diálogos das grandezas do Brasil. $2^{\mathrm{a}}$ ed. Recife: Imprensa Universitária; 1966.

Minayo MC de S. O conceito de representações sociais dentro da sociologia clássica. In: Guareschi PA e Jovichelovicht $S$, org. Textos em representações sociais. $5^{\text {a }}$ ed. Petrópolis; Vozes, 1999, 89-111.

Morata TC. An epidemiological study of effects of exposure to noise and organic solvents on workers hearing and balance. USA; 1990. [Tese de doutorado Universidade de Cincinnati].

Munhoz. Desenvolvimento sustentável e Educação ambiental. Em aberto Brasilia, v.10, n 49, p.63-64, Janeiro/Março; 1991.

Narvai PC. Odontologia e saúde bucal coletiva. Hucitec, São Paulo; 1994

Nascimento AS. Biologia do caranguejo-uçá (Ucides cordatus). Aracajú: Adema; 1993.

Nascimento AS e col. Estudo bio-ecológico do caranguejo-uça e das características dos manguezais do Estado do Sergipe. Sergipe: Adema; 1984.

Neiva GS. Subsídios para a política pesqueira nacional. IBAMA, Documento técnico único 1990; 55-67.

Nogueira J.Viver sobre o lixo e sobreviver do lixo: um estudo com catadores de lixo em Vitória - ES. Espírito Santo;1996. [Dissertação de Mestrado UFES Universidade Federal do Espírito Santo].

Nordi N. Os catadores de caranguejo-uçá (Ucides cordatus) da Região de Várzea Nova (PB): uma abordagem ecológica e social. São Paulo; 1992. [Dissertação de Mestrado Universidade Federal de São Carlos]. 
Novaes W. Agenda 21. In: Trigueiro A, coordenador. Meio Ambiente no Século 21: 21 especialistas falam da questão ambiental nas suas áreas de conhecimento. Rio de Janeiro: Sextante; 2003. p. 323-332.

Paim JS. Abordagens teórico-conceituais em estudos de condições de vida e saúde: notas para reflexão e ação. In: RB Barata (org.). Condições de vida e saúde. Rio de Janeiro: Abrasco; 1997. p.7-30.

Pelicioni MCF. Educação ambiental, qualidade de vida e sustentabilidade Saúde e Sociedade; 1998; 7 (2): p. 19-31.

Philippi Jr. A, Pelicioni MCF, editores. Educação Ambiental: Desenvolvimento de Cursos e Projetos. 2a São Paulo: Signus; 2002.

Pinto VG. Saúde bucal coletiva. $4^{\mathrm{a} e d . ~ S a n t o s ~(S P) ; ~} 2000$.

Plano Nacional de gerenciamento Costeiro $n^{\circ} 01$ de 21 de Novembro de 1990 da comissão interministerial para os recursos do mar (CIRN) e pelo CONAMA Conselho Nacional do meio ambiente.

Portaria para a região Sudeste e Sul $n^{\circ} 104$, de 27 de Julho de 1998. IBAMA (Instituto Brasileiro do Meio Ambiente e dos Recursos naturais renováveis).

Pomeroy R.S. A Process for community - based fisheries co-management. NAGA/CLARM Quaterly, 21 (1);1998. p. 71-76.

Pomeroy RS e Williams MJ. Fisheries co-management and small - scale fisheries: a policy brief. Clarm, Manilla, Philippines; 1994.

Porto VCM. Saúde bucal e condições de vida: uma contribuição do estudo epidemiológico para a inserção de atenção à saúde bucal no SUS. São Paulo; 
2002. [Dissertação de mestrado. Universidade Estadual Paulista Júlio de Mesquita Filho, Faculdade de Medicina de Botucatu].

Reigota M. Fundamentos teóricos para a realização da educação ambiental popular. Brasília: Em aberto; 1991. v.11.

Reigota M. Educação Ambiental: Compromisso Político e Competência Técnica. In: Philippi Jr. A, Pelicioni MCF, editores. Educação Ambiental: Desenvolvimento de Cursos e Projetos. $2^{2}$ ed. São Paulo: Signus; 2002. p. 33-35

Rentzsch M, Prescher W, Tolksdore M. New models, methods of evaluation and design solutions for combined load and strain. Arch Compl Environ Studies 4 (3): p.55-63; 1992.

Resolução 004/85, sobre Reservas Ecológicas Art. $2^{\mathrm{a}}$ da Lei $\mathrm{n}^{\circ} 4771$, de 15 de setembro de 1965 "Resolução do Conama”.

Reveret J.P. La pratique des pêches. Comment gérer une ressource renouvable. Paris: L'Harmattan; 1991.

Richardson R V. Pesquisa social - métodos e técnicas. $3^{\text {a }}$ ed. São Paulo: Atlas; 1999.

Robins LN, Regier DA. Psychiatric Disorders in América. New York: Mac Millan, 1991.

Rodrigues AMT. Diagnóstico Sócio-Econômico e a Percepção ambiental das comunidades de Pescadores Artesanais do Entorno da Baía da Babitonga (SC): Um subsídio ao gerenciamento costeiro. Santa Catarina; 2000 [Dissertação de Mestrado - UFSC]. 
Rosa FCF. A baía de Vitória na história econômica do Brasil. Revista do Instituto Histórico e Geográfico do Espírito santo. 1957; 17: 16-27

Rossi EA, Goldstein GB, Tabibzadeh I. Urbanization and health in developing countries: a challenge for health fol all. World Health Stat 1991; 44 (4): 186244.

Ruschi A. Fitogeografia do Estado do espírito santo: condições gerais sobre a distribuição geral da flora no espírito santo. Boletim do Museu de Biologia professor Mello Leitão. 1950; (1): 1-353.

Ruschi A. O mapa fitogeográfico atual do Estado do Espírito Santo. Boletim do Museu de Biologia professor Mello Leitão. 1969; (30): 1-49.

Ruschi A. As restingas do Estado do Espírito Santo. Boletim do Museu de Biologia professor Mello Leitão. 1979; (91): 1-41.

Ruschi A. Orquídeas do Estado do Espírito Santo. Rio de Janeiro, Expressão e Cultura. 1986; p. 278.

Rybak LP. "Hearing". The effects of chemicals. Otolaryngol Head Neck Surg. 1992. 106: p.677-686.

Sajise P. Community-based resource management in the Philippines: perspectives and experiences. Hirtshals (Denmark); 1995 [A paper presented at the fisheres co-management workshop at the North See Center].

Schaeffer MB. Some considerations of population dynamics and economics in relation to the management of the commercial marine fishers. Journal of Fisheries Research Board of Canada, Canadá, 1957; 14: 5. 
Silva AG. A cobertura vegetal do Estado do Espírito Santo: preservação e renovação. Revista Cult. UFES. 1986; 11(36): 21-34.

Silva EV, Brandão SF. Estudo de um campo semântico da linguagem do pescador norte-fluminense. In: Encontro de Ciências Sociais e o Mar. São Paulo: Programa de Pesquisa e Conservação de Áreas Úmidas no Brasil, IOUSP, FORD, UICN, 1988. p.226-235.

Silva SJ, coordenador. Saberes e Fazeres: a pesca tradicional na tha das Caieiras. FAESA; 2004.

Silveira Filho ADA. A saúde bucal no PSF: o desafio de mudar a prática. Brasil, Programa Saúde da Família; 2002.

Smith IA. Mismanagement of England fisheries and same correcti measures. CLARM, Manila, 1982.

Soares EL. Educação em saúde bucal nas escolas estaduais do $1^{\circ}$ grau do município de São Paulo. Tese de doutorado. Universidade de São Paulo, Faculdade de Saúde Pública, São Paulo; 1988.

Souza CR. Dinâmica e Gestão Ambiental em Agroindústria: uma análise sos a ótica da Teoria das representações sociais.Lavras (MG); 2003 [Dissertação de mestrado apresentada à Universidade Federal de Lavras como parte das exigências do Curso de Mestrado em administração, área de concentração em Gestão Social, Ambiente e Desenvolvimento].

Souza G.S de. Tratados descritivos do Brasil em 1587. $4^{a}$ ed. São Paulo: Companhia Editora Nacional/ EDUSP; 1971

Souza MT de. Efeitos auditivos provocados pela interação entre ruído e solventes - uma alternativa em audiologia, voltada a saúde do trabalhador. 
São Paulo; 1994 [Dissertação de mestrado Pontificia Universidade Católica de São Paulo].

Stebbins RA. Fitting in: the researcher as learned and participant. Quality and Quantity; 1987. v.21.

Trigueiro A, coordenador. Meio Ambiente no Século 21: 21 especialistas falam da questão ambiental nas suas áreas de conhecimento. Rio de Janeiro: Sextante; 2003.

Tristão M. Pedagogia Ambiental: uma proposta baseada na interação. Vitória (ES); 1992. [Dissertação de Mestrado - Universidade Federal do Espírito Santo].

Vale CC. Homens e caranguejos: uma contribuição geográfica ao estudo dos manguezais da baía de Vitória (ES). In: Simpósio sobre Ecossistemas da Costa Brasileira; 1993; Serra Negra, (BR). São Paulo: ACIESP; 1994. p.269-273.

Varoveska $\mathrm{O}$, Verçosa C. Ocorrência, aspectos bioecológicos e concentração de metais pesados em Portunidae (Crustácea, decapoda) da praia Imbuca, Ilha de Paquetá, Rio de Janeiro. VII COLACMAR. Congresso Latino Americano de Ciências do Mar. Santos, Sp, 1997.

Vergara WF. Manguezal em Cordéis. Rio de Janeiro: Universidade do Estado do Rio de Janeiro, Sub-reitoria passa assuntos comunitários;1994.

Vieira PF, Ribeiro MA, Franco RM, Cordeiro RC, organizadores. Porto Alegre Desenvolvimento e Meio Ambiente: A contribuição de Ignacy Sachs. Florianópolis: Pallott/Aped; 1998.

World Health Organizations. Creating health cities in the $21^{\text {st }}$ century. Geneva; 1996 (Who-OES,9). 
ANEXOS 


\title{
Catadores de Caranguejos no Município de Vitória (ES) \\ Roteiro de entrevista
}

$1^{2}$ Parte: Dados sociais

1) Nome:

2) Endereço:

3) Localidade:

4) Idade:

5) Estado civil:

( ) solteiro(a)

( ) casado(a) (de fato e de direito)

( ) separado(a)

( ) viúvo(a)

6) Seu esposo(a)/companheiro(a) está empregado(a)? ( )Sim ( ) Não

6.1 Se sim, em que ele/ela trabalha?

6.2 Se não, por quê?

7) $\mathrm{O} \mathrm{Sr} / \mathrm{Sra}$ tem filhos?

7.1 Se sim, quantos?

8) $\mathrm{O} \mathrm{Sr} / \mathrm{Sra}$ freqüentou alguma escola? Município: Vitória UF: ES

$8.1 \mathrm{Em}$ caso positivo até que ano o $\mathrm{Sr} / \mathrm{Sra}$ freqüentou a escola?
( ) não foi alfabetizado
( ) $2^{\circ}$ Grau completo
( ) $1^{\circ}$ Grau completo
( ) $1^{\circ} \mathrm{Grau}$ incompleto
( ) $2^{\circ}$ Grau incompleto
( ) Outro. Qual?

9) Há quanto tempo o $\mathrm{Sr} / \mathrm{Sra}$ reside nesse local?

10) A moradia do $\mathrm{Sr} / \mathrm{Sra}$ é:
( ) própria
( ) alugada
( ) emprestada
( ) outro Qual?

11) Quantas pessoas moram com o $\mathrm{Sr} / \mathrm{Sra}$ nesta casa ?

$2^{\mathbf{a}}$ Parte: Serviço de infra-estrutura

12) A casa do $\mathrm{Sr} / \mathrm{Sra}$ possui água encanada?

12.1 Se não, a água é coletada em:

ANEXO 1

\author{
(n)
}




\section{$3^{2}$ Parte: Aspectos econômicos/ profissionais}

16) Qual é a principal fonte de renda da família?

17) $\mathrm{O} \mathrm{Sr} / \mathrm{Sra}$ tem outro trabalho além da cata de caranguejo? ( ) Sim ( )Não

17.1 Se sim, qual?

17.2 Se não, por quê?

18) O Sr/Sra Já trabalhou como empregado (a)?

19) Por quanto tempo $\mathrm{Sr} / \mathrm{Sra}$. trabalhou empregado (a)?

20) $\mathrm{O} \mathrm{Sr} / \mathrm{Sra}$ prefere trabalhar no mangue ou como empregado (a)?

21) Com a cata de caranguejo a família do $\mathrm{Sr} / \mathrm{Sra}$ recebe:

( ) 1 salário mínimo

( ) entre 1 e 2 salários mínimos

( ) entre 2 e 3 salários mínimos

( ) entre 3 e 5 salários mínimos

( ) mais de 5 salários minimos

22) $\mathrm{O} \mathrm{Sr} / \mathrm{Sra}$ recebe alguma outra renda?

22.1 Se sim, de onde?

( ) Sim ( ) Não
( ) pensão
( ) aposentadoria
( ) aluguel
( ) outro. Qual?

23) Quanto tempo faz que o $\mathrm{Sr} / \mathrm{Sra}$ trabalha no mangue?

24) Quantos dias por semana o $\mathrm{Sr} / \mathrm{Sra}$ trabalha no mangue?

24.1 Quais dias da semana?

25) Que tipo de caranguejo o $\mathrm{Sr} / \mathrm{Sra}$ costuma catar?

26) Qual a técnica que o Sr/Sra utiliza para pegar o caranguejo?
( ) braço
( ) tapando
( ) cavadeira
( ) com redinha;
( ) Outro. Qual?

26.1 Por que o $\mathrm{Sr} / \mathrm{Sra}$ prefere essa(s) técnica(s)

27) Quantas dúzias de caranguejo o $\mathrm{Sr} / \mathrm{Sra}$ pega por semana:

28) O Sr/Sra costuma comer caranguejo? () Sim () Não. Por quê?

29) Além do caranguejo o Sr/Sra pega outros produtos do mangue?

29.1 Se sim, quais?

30) $\mathrm{O}$ que o $\mathrm{Sr} / \mathrm{Sra}$ costuma fazer com esses produtos?

\section{$4^{\mathrm{a}}$ Parte: Organização social}

31)O Sr/Sra faz parte de alguma associação?

( ) Sim ( ) Não.

31.1 Se sim,Por quê?

31.2 Se não,Por quê?

32) $\mathrm{Na}$ comunidade do $\mathrm{Sr} / \mathrm{Sra}$ existem:
( ) colônias
( ) associação de moradores
( ) sindicato
( ) cooperativa
( ) outro. Qual?

33) $\mathrm{O} \mathrm{Sr} / \mathrm{Sra}$ acha que essas organizações auxiliam na solução de problemas da comunidade?
( ) $\mathrm{Sim}$
( ) Não

33.1 ( ) Se sim, por quê?

33.2 ( ) Se não, por quê? 
34) O Sr/Sra acha que a fiscalização do governo na área do mangue têm sido efetiva na sua área? ( ) $\operatorname{Sim}$ ( ) Não

34.1 ( ) Se sim, por quê?

34.2 ( ) Se não, por quê?

$5^{2}$ Parte: Aspectos ecológicos

35) Quais são as mudanças que o $\mathrm{Sr} / \mathrm{Sra}$ tem notado na cata do caranguejo?

36) O Sr/Sra notou diferença na qualidade da água na baía? ( ) Sim

( ) Não

36.1 Se sim, qual?

37) Quanto ao número de catadores atuando na região:

( ) aumentou

( ) diminuiu

( ) ficou igual

( ) não sabe

37.1 Caso tenham aumentado. Quem está trabalhando na cata do caranguejo da região?

38) Quem deveria cuidar do manguezal?

39) Como o Sr/Sra vê o local onde trabalha?

A participação do $\mathrm{Sr} / \mathrm{Sra}$ foi muito importante.

Data da entrevista:

Aplicado por: 
Prontuário:

Data: ......................

FICHA CLÍNICA INTERDISCIPLINAR

ANEXO 2

Nome do paciente:

Aluno responsóvel pelo preenchimento desta ficho:

Professor responsóvel pelo preenchimento desta ficha:

Curso(s):

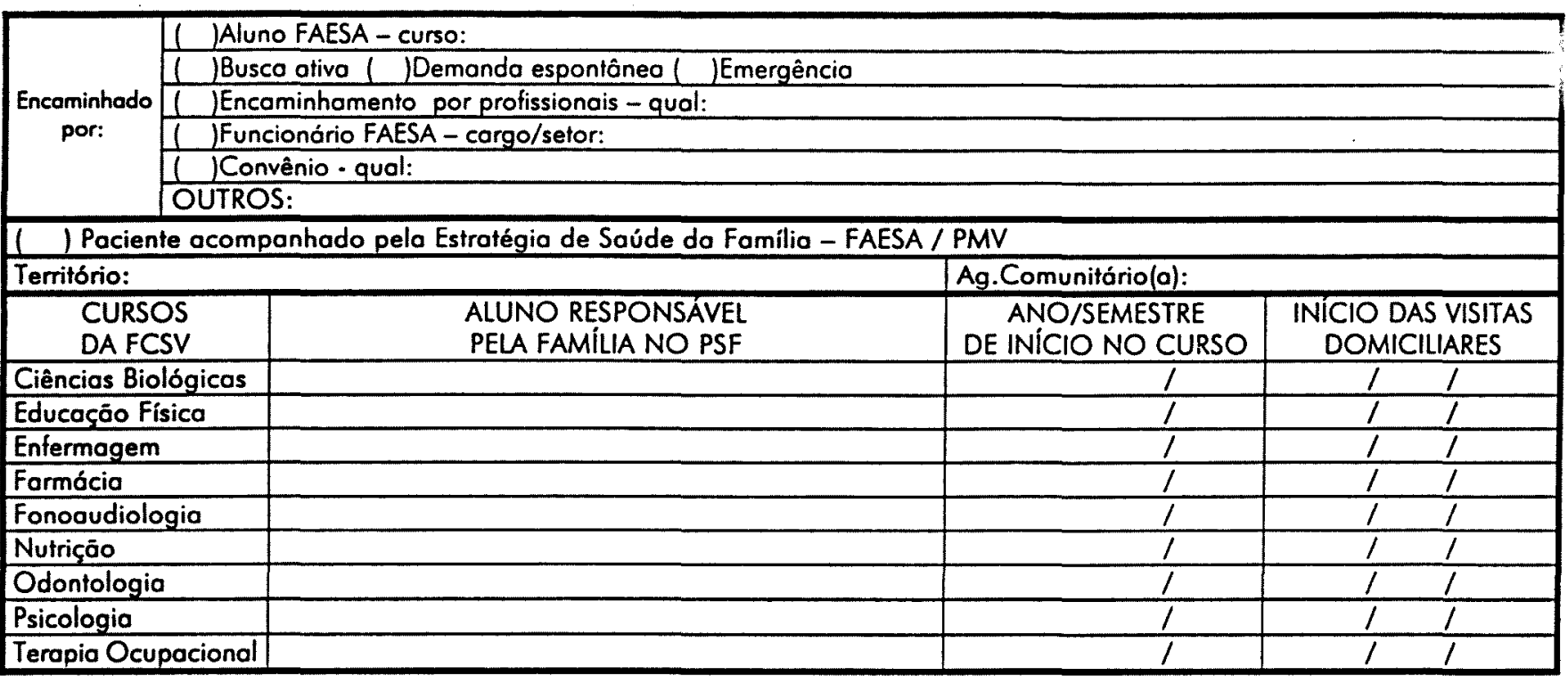

\section{ALERTA}

JALERGIA - Substôncio:

LHIPERTENSĀO ARTERIAL - Pressäo Arterial (mmHg):

PNE: \ ISIM I NNÃO

JAPRESENTANDO ENFERMIDADE - TipO:

U USANDO MEDICAMENTO - OBSERVAR NO QUADRO CONSTANTE DESTA FICHA

JÁFOI HOSPITALIZADO(A): ( ISIM U UNÁO

APRESENTA OU JÁ APRESENTOU:

\begin{tabular}{|c|c|c|c|c|}
\hline ALTERAÇOES HORMONAIS & CÁNCER & CARDIOPATIA & CHOQUE ANAFILÁTICO & CONVULSAOO \\
\hline DEPRESSAO & DIABETES & EPILEPSIA & FEBRE REUMÁTICA & HEMOFILIA \\
\hline HEPATITE & HEERPES & HIPERTIREOIDISMO & HIPOTIREOIDISMO & HIV POSITIVO \\
\hline $\begin{array}{l}\text { PROBLEMAS COM } \\
\text { CICATRIZACÃO }\end{array}$ & $\begin{array}{l}\text { PROBLEMAS NAS } \\
\text { ARTICULACCOES }\end{array}$ & PROBLEMAS RENAIS & REAÇAO POS-ANESTESIA & TUBERCULOSE \\
\hline
\end{tabular}

OUTROS:

Doador de órgãos: ( / SIM / / NAO Grupo sangüineo-ABO/Fator Rh:

En caso de emergência procurar:

Telefone:

Pociente

Aluno 
Prontuário:

Data: .......................

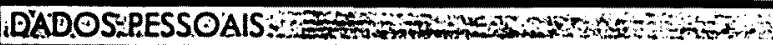

Documento de Identificaçāo:R.G:

Outro documento- Eategoria:

\begin{tabular}{|l|l|l|l|l|}
\hline Data de Nascimento: $/$ & Idade: & anos & Sexo: $(M)(F)$ & Estado Civil: \\
\hline Nacionalidade: & & Naturalidade:
\end{tabular}

Cor: ( Branco ( Moreno ( INegro |Procedência: ( ) zona urbano ( ) zona rural Religiōo:

Endereço residencial: Av./Rua:

\begin{tabular}{|l|l|l|l|}
\hline & $N^{0}:$ & Complemento: \\
\hline Bairro: & Cidade: & Estodo: & C.E.P.: \\
\hline Ponto de referéncia:
\end{tabular}

Endereço comercial: Av./Rua:

\begin{tabular}{|l|l|l|l|l}
\hline \multicolumn{2}{l|}{} & $\mathrm{N}^{\circ}:$ & Complemento: \\
\hline Bairro: & Cidade: & Estado:. & C.E.P.: \\
\hline Telefones: Res.: & Com.: & Cel.: & \\
\hline
\end{tabular}

Telefones para recado - acrescentar nome(s):

Protissāo:

Ocupoçăo onterior:

Possui algum tipo de assistência ò saúde particular? ( ) NÁ ( ISIM Qual(is)?

\begin{tabular}{|l|l|}
\hline Cirurgiōo-Dentista: & Telefone: \\
\hline Médico: & Telefone: \\
\hline Outros profissionais: & Telefone: \\
\hline
\end{tabular}

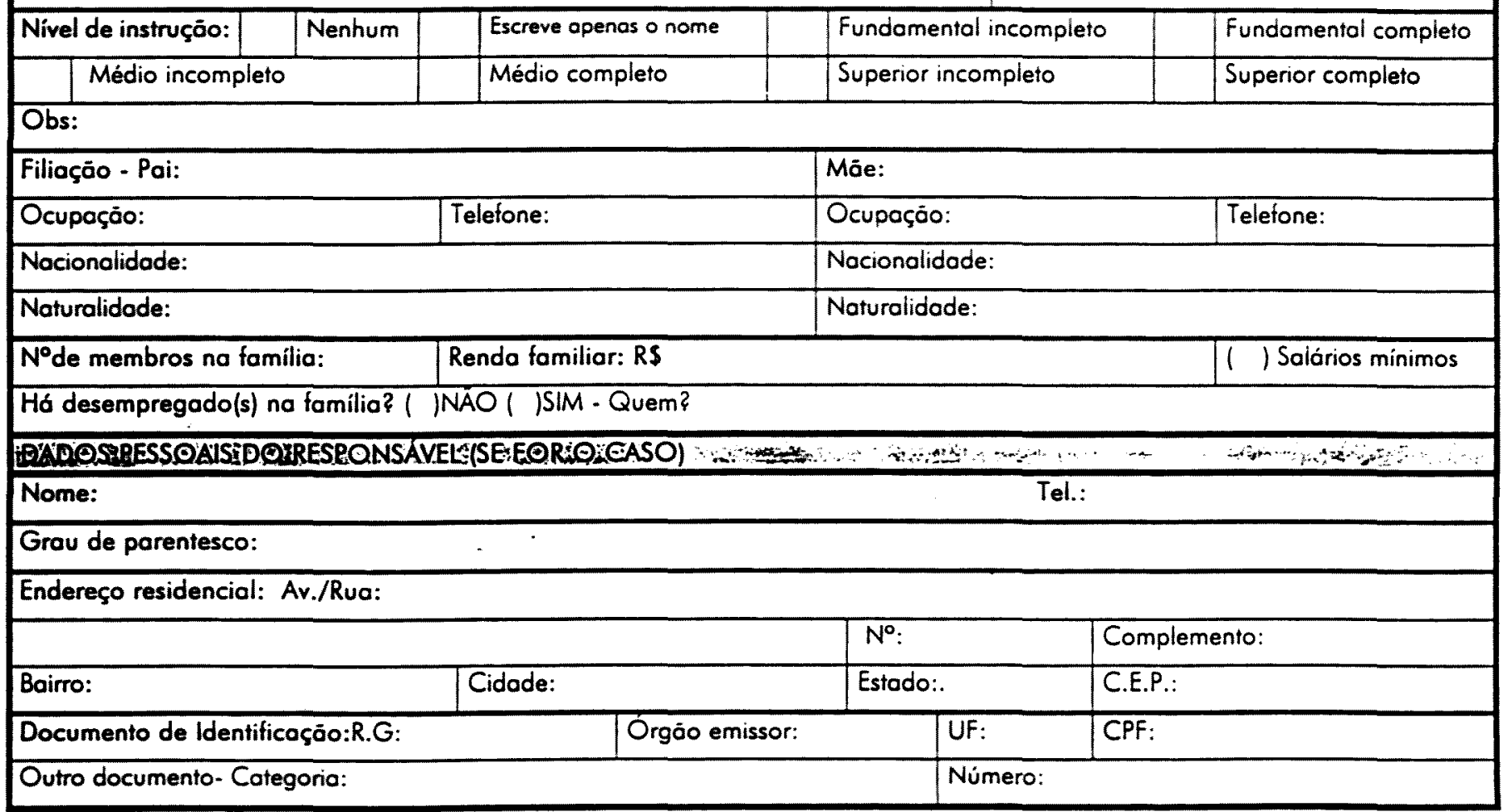


Data:........................

CONSENTIMENTO INFORMADO E TERMO DE COMPROMISSO (AUTORIZACÄA)

Através desta autorização por mim assinada, afirmo que fui informado que o atendimento feito pela Associação Educacional de Vitória, FAESA, à minha pessoa ou às pessoas pelas quais sou responsável, tem como objetivo principal o ensino e a pesquisa e, por isso, será feito por alunos, professores e outros membros que fazem parte de uma equipe de várias áreas especializadas da Faculdade de Saúde.

Concordo totalmente com o tratamento, realização de exames que forem necessários para 0 conhecimento de uma doença física ou mental, planejamento, tratamento e acompanhamento de tudo que for feito á minha pessoa, retenção das radiografias, fotografias e fichas que fazem parte do arquivo da instituição FAESA, além do uso de materiais para fins de ensino e pesquisa, como tornar público em revistas, jornais, internet, palestras e outras atividades, todas de cunho cientifico no Brasil e em outros paises, respeitando 0 código de ética.

A continuidade do meu tratamento dependerá da minha autorização e comparecimento para a realização dos exames pedidos, do meu interesse e participação, do comparecimento no dia e horário marcado e da observação e cumprimento das normas de funcionamento da Clínica e dos pedidos feitos pelos professores e alunos da Instituição. Caso eu falte às consultas marcadas por 2 (duas) vezes seguidas sem avisar, 24 horas antes da consulta, ou não concorde em submeter-me a todo 0 tratamento sugerido pelos profissionais da Faculdade de Ciências da Saúde, poderei ocasionar prejuizos ao tratamento a mim sugerido, podendo inclusive ser suspenso pela instituição.

Sei que o agendamento é feito por disciplina, ou seja, o tratamento realizado em uma disciplina clínica não garante $o$ atendimento em qualquer outra disciplina do mesmo curso ou de outro curso da Faculdade de Ciências da Saúde e que se for preciso passar por outra disciplina, o agendamento será feito se tiver vaga e respeitando a lista de espera.

Concordo que, por ser uma clínica escola, poderei ter meu tratamento paralisado durante as férias (nos meses de Janeiro e Julho) e que o término do meu tratamento estará sujeito à alteraçăo caso surja novas necessidades de atendimento.

Fui informado que talvez eu tenha a responsabilidade de pagar alguma quantia para o tratamento, e que nesse caso serei avisado dos valores e como posso pagar antes de fazer o tratamento sugerido, podendo assim aceitá-lo ou não. Sei que alguns exames deverão ser realizados fora da FAESA.

Estou ciente de que as perguntas feitas durante a entrevista serão utilizadas para a melhor compreensão do meu estado de saúde, e que as informaçōes necessárias para um bom atendimento serão guardadas em sigilo total e será de minha total responsabilidade a ocorrência de qualquer problema antes, durante ou após o meu tratamento, caso tenha sido causado por informações não mencionadas ou respostas que não são verdadeiras.

Vitória - ES. '

Nome e assinatura do responsável (se for o caso) 
Prontuário:

Data: .......................

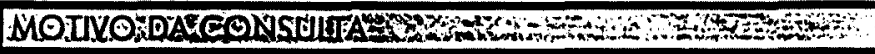

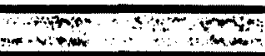

\section{GERAL} NÁO

OBSERVACŌES

Sente secura na boca durante o dia?

Sua gengiva sangra facilmente?

Costuma respirar pela boca?

Range os dentes à noite (bruxismo)?

Você faz "apertamento" dos dentes?

Usa prótese?

Está sob tratamento de saúde?

Já foi hospitalizado?

Consome bebida alcoólica?

Se SIM: ( ) Socialmente

Fumo?

() Näo socialmente

Se SIM: (1)cigarro (2)charuto (3)cachimbo (4)outros:

Consome drogas? (Se sim, listor tipos abaixo)

Faz uso de medicamentos regularmente?

Já foi submetido o (1)radioterapio

elou

(2)quimioterapia?

Pratica alguma atividade física?

Sente dor de cabeça e/ou pescoço?

Tipo:

Qual?

Por quê?

\begin{tabular}{l|l}
\hline Inicio? & Quantidade/Freqüência? \\
\hline
\end{tabular}

\begin{tabular}{|l|l}
\hline Início? & Quantidade/Freqüência?
\end{tabular}

11

$1)$

Inicio?

Quantidade/Freqüència?

OS MEDICAMANTOS DEVERĀO SER LISTADOS NA FICHA ESPECIFICA

\begin{tabular}{|l|l}
\hline Quando? & Regiōo do corpo afetada? \\
\hline
\end{tabular}

$1)$

1

Qual (is)?

Freqüência?

Freqüêncio?

Quanto ao seu peso nos últimos 03 meses:( ) Gonhou ( Perdeu ( Manteve MOTIVO:

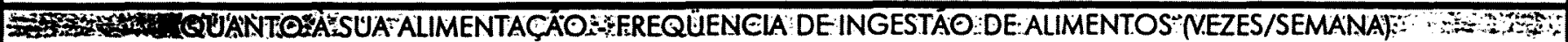

\begin{tabular}{|c|c|c|c|c|c|c|c|}
\hline & NUNCA & 102 & 3 ou MaIS & & NUNCA & 102 & 3 ou MAIS \\
\hline Massas & & & & Sucos de frutas & & & \\
\hline Biscoitos/bolos/pāes & & & & Frutas & & & \\
\hline Frituras & & & & Hortaliços & & & \\
\hline Refrigerantes & & & & Carne vermelha & & & \\
\hline Cofé & & & & Carne branca & & & \\
\hline Chó & & & & Leite e derivados & & & \\
\hline Doces & & & & Achocolatados & & & \\
\hline Outros: & & & & Outros: & & & \\
\hline & & & & & & & \\
\hline & & & & & & & \\
\hline & & & & & & & \\
\hline & & & & & & & \\
\hline
\end{tabular}


Prontuário:

Data: .......................

\begin{tabular}{|c|c|c|c|}
\hline ALERGIAS: & NAOO & $\operatorname{siM}$ & OBSERVAÇÓES .. \\
\hline E alérgico a algum medicamento? & & & ()Sulfo ()Penicilina ( )Outros medicamentos - \\
\hline \multirow[t]{3}{*}{ Já foi submetido a alguma onestesio? } & & & Tipo/motivo: \\
\hline & & & Tipo/motivo: \\
\hline & & & Tipo/motivo: \\
\hline Teve alguma reação anormal? & & & Qual(is): \\
\hline Jó teve algum choque anafilático? & & & Qual substância: \\
\hline
\end{tabular}

Outros:

DISTURBIOS:CARDIO-VASCULARES

Afere sua pressāo arterial com freqüêncio?

Sente falta de ar ou cansaço ao fazer exercicio leve?

Sente dores no peito?

Usa marcapasso ou prótese cardiaca?

Outros:

DISTURBIOS SANGUINEOS

Já recebeu transfusāo sangüinea?

Já se submeteu a alguma cirurgia?

Apresentou sangramento anormal?

Sente fadiga ou fraqueza?

Outros:

DISTURBIOS RESPIRATÓRIOS

Apresento dores de garganta treqüentemente?

Tem dificuldade de respirar?

Apresenta tosse persistente?

Outros:

\section{DISTURBIOS NEUROLOGICOS}

Já apresentou alguma lesảo ou trauma na cabeça?

Apresenta dores de cobeça freqüentemente?

Outros:

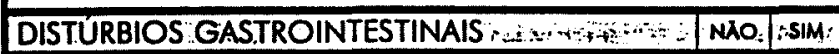

Já vomitou sangue?

Vomito freqüentemente?

Outros:

DISTURBIOSTRENAIS WAS

Faz hemodiólise?

Urina com frequêência? (mais de 5 vezes oo dia)

Sente dor durante a micçāo?

Costuma acordar para ir ao banheiro ?

Outros:

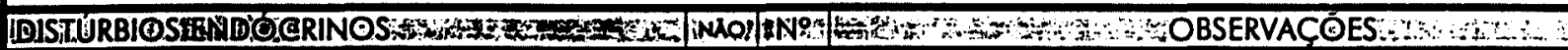

Sente (1)muita sede? (2) muita fome (polifagia)?

Outros:

) vez(es) por semona

\begin{tabular}{|l|l|l|l|l|}
\hline & & & Hó quanto tempo? & $($ ) vez(es) por semona \\
\hline & & & \\
\hline
\end{tabular}

OBSERVACOOES

\begin{tabular}{l|l|l|l|l|}
\hline & NAO & SIM & $\ldots \ldots$ & OBSERVACÓES \\
\hline & & & Qual a média? Sistólica: & Diaslólica: \\
\hline & & & & \\
\hline
\end{tabular}

NAO $\operatorname{SIM} \mid$

\begin{tabular}{|c|c|c|}
\hline & & Quando? \\
\hline & & Por quê? \\
\hline & & Qual(is)? \\
\hline & & Motivo: \\
\hline & & \\
\hline
\end{tabular}

OBSERVAÇÓES

OBSERVAÇŌES

\section{OBSERVAÇŌES}

Como?

OBSERVAÇŌES

For quê?

Por quê?

somente ao deitar-se

1otivo:

$4 x=5$ 
Prontuário:

Data: ........................

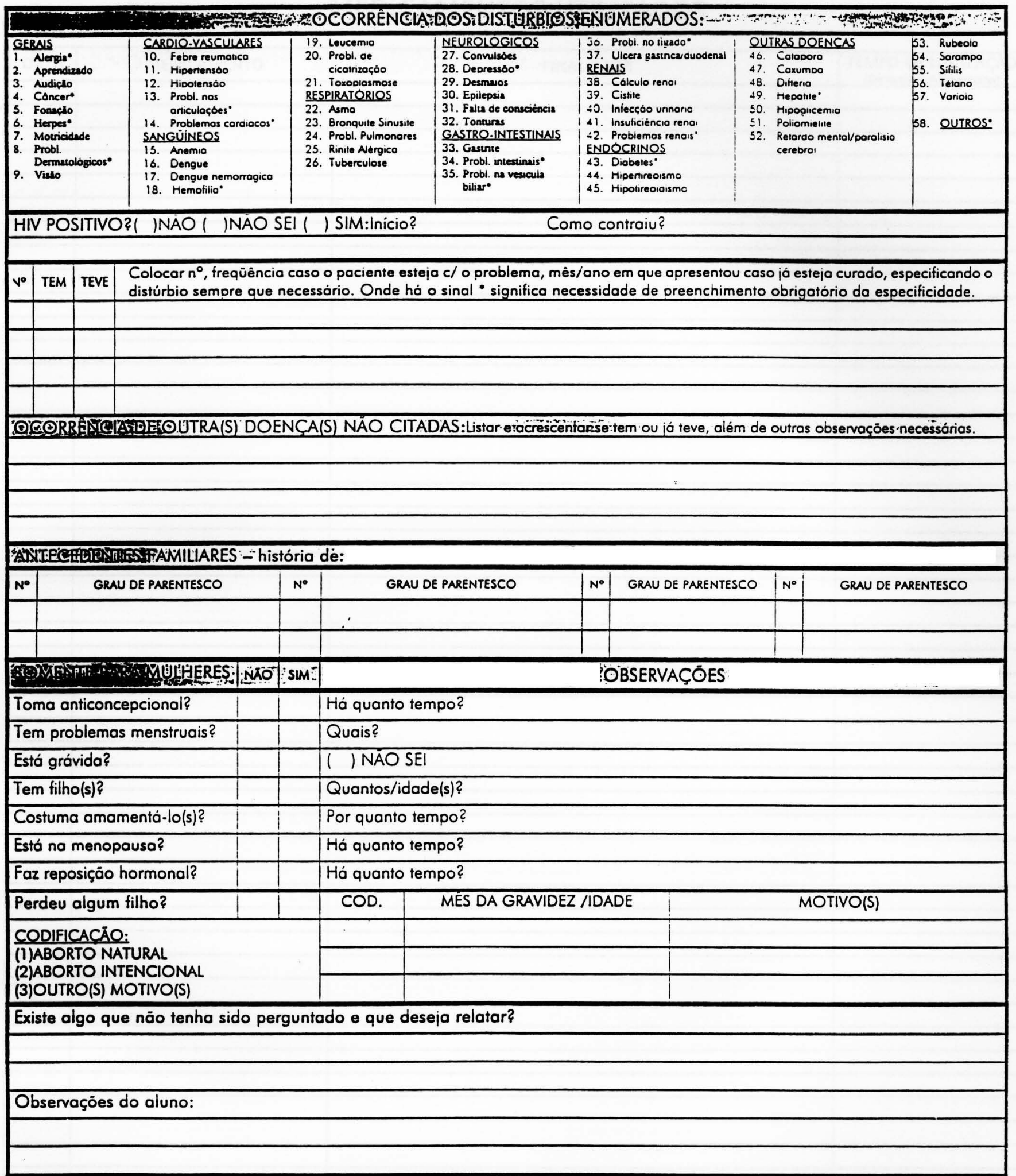

Declaro que os dados por mim informados sáo verdadeiros. Comprometo-me a informar quaiquer alteraçáo que posso ocorrer no meu quadro de saúde, bem como qualquer alteração cadastral.

Vitória, ES, __ de de 


\section{MEDICAMENTOS UTILIZADOS}

\begin{tabular}{|c|c|c|c|}
\hline DATA & MEDICAMENTO & FINALIDADE & 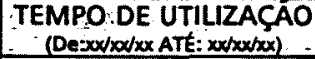 \\
\hline & & & \\
\hline & & & \\
\hline & & & \\
\hline & & & \\
\hline & & & \\
\hline & & & \\
\hline & & & \\
\hline & & & \\
\hline & & & \\
\hline & & & \\
\hline & & & \\
\hline & & & \\
\hline & & & \\
\hline & & & \\
\hline & & & \\
\hline & & & \\
\hline & & & \\
\hline & & & \\
\hline & & & \\
\hline & & & \\
\hline & & & \\
\hline & & & \\
\hline & & & \\
\hline & & & \\
\hline & & & \\
\hline & & & \\
\hline & & & \\
\hline & & & \\
\hline & & & \\
\hline & & & \\
\hline & & & \\
\hline & & & \\
\hline & & & \\
\hline & & & \\
\hline & & & \\
\hline & & & \\
\hline & & & \\
\hline & & & \\
\hline & & & \\
\hline
\end{tabular}




\section{FICHA DE HISTÓRICO ODONTOLÓGICO}

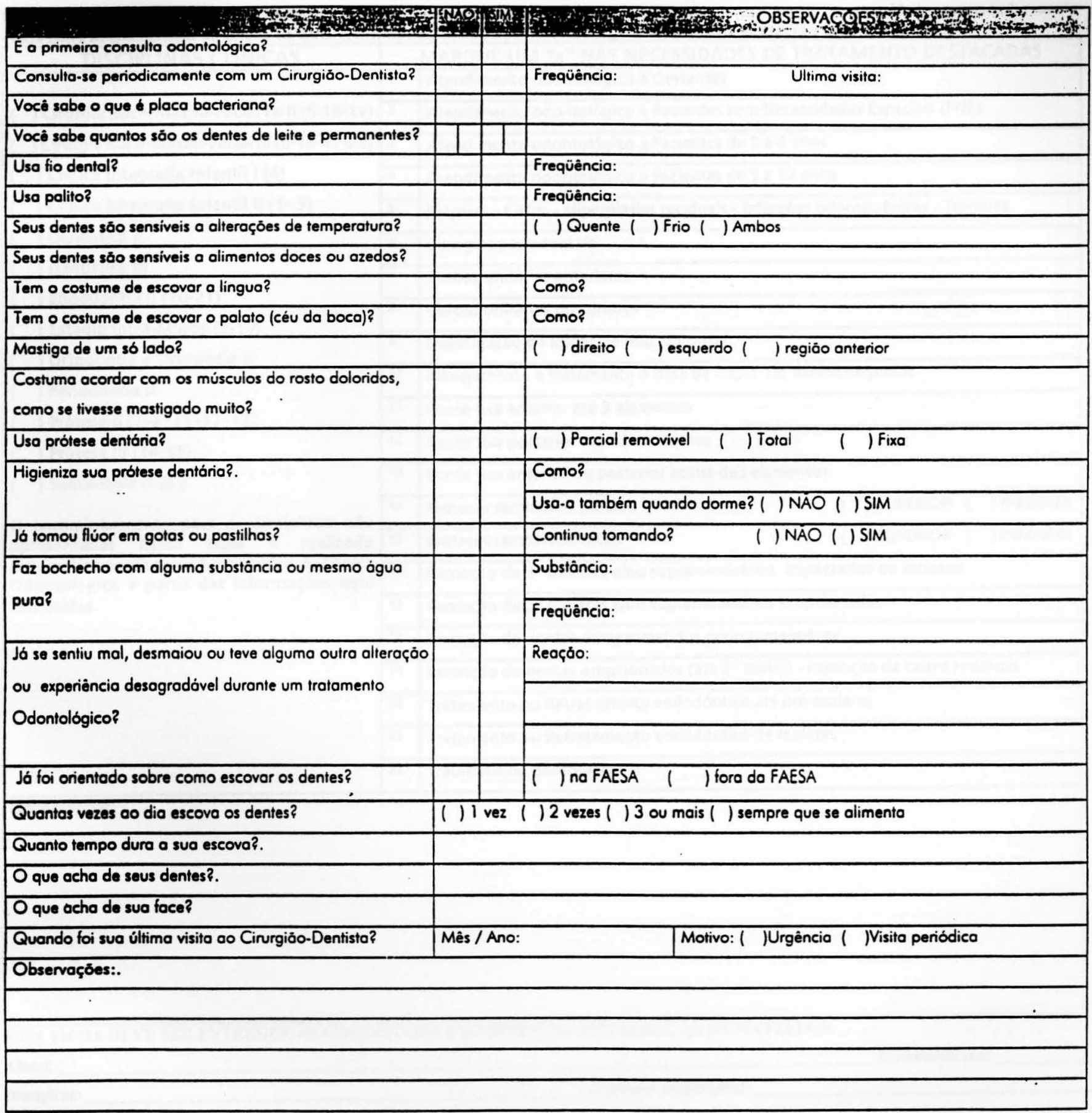

Declaro que os dados por mim informados são verdadeiros. Comprometo-me a informar qualquer alteração que possa ocorrer sobre os questionamentos acima.

Vitória, ES, de de 


\section{LEVANTAMENTO DE NECESSIDADES}

DATA:

1

PACIENTE:

DATA DE NASCINENTO

TELEFONE(S):

Marcar as disciplinas para as quais o paciente deverí ser encaminhado para tratamento, assinalando com um " $\mathrm{X}$ " a necessidade apresentada, caso esteja entre as enumeradas na coluna da direita, facilitando, assim, o processo de organizaça de lista de espera e encaminhamento.

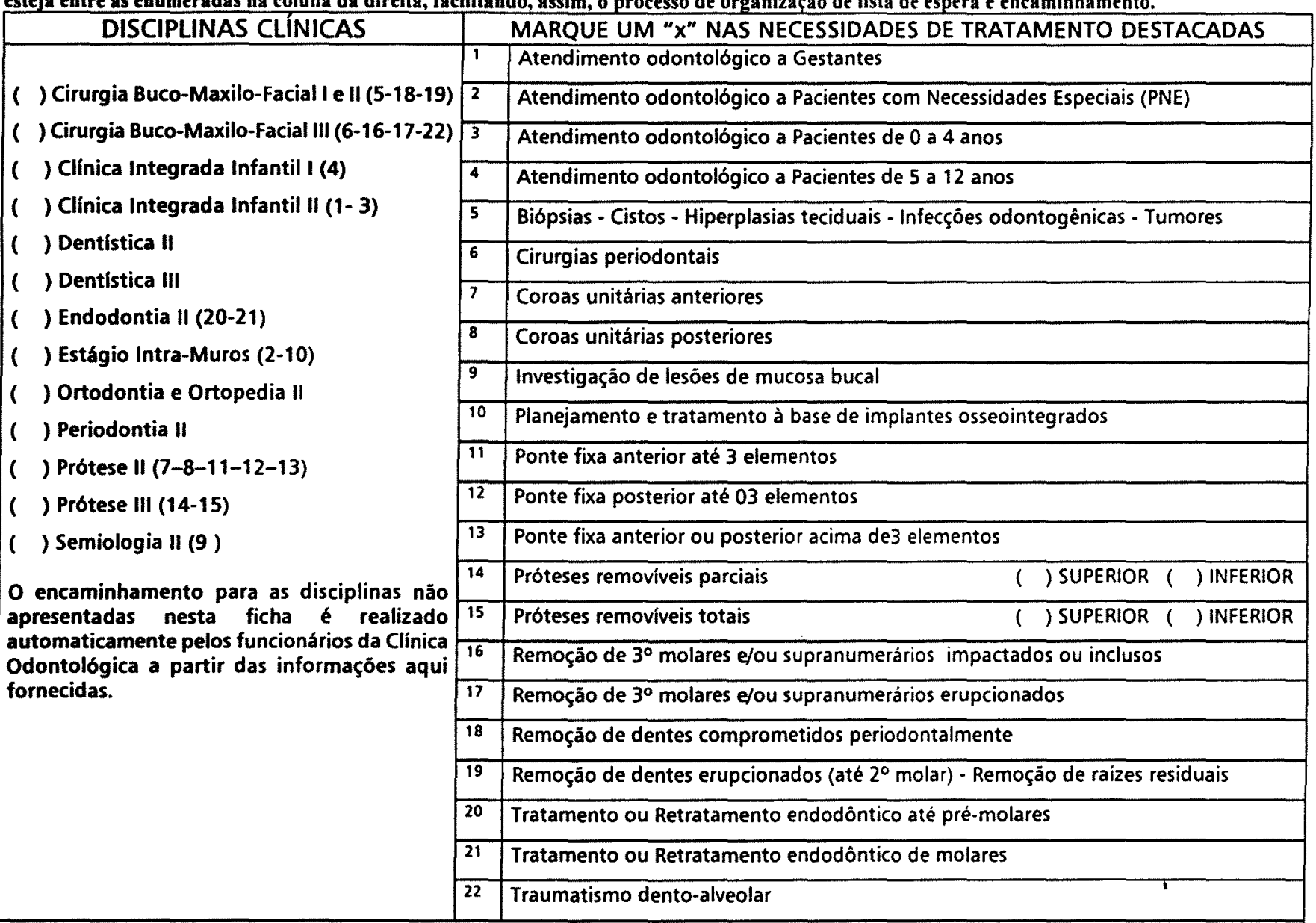

Observaçōes:

ESSA FICHA DEVE SER ENTREGUE ÁS FUNCIONÁRIAS DO SETOR DE DISTRIBCIÇĀO DE MIATERIAIS.

Aluno: Período/turma:

Disciplina: Professor responsável: 
Protocolo de Avaliação- Terapia Ocupacional

Alunos Responsáveis:

- Dados Gerais

Nome do paciente:

Idade:

anos Data de Nascimento:

Endereço:

Naturalidade:

L Telefone:

Escolaridade:

Sexo: ( )F ( )M

Filhos:

Estado Civil:

Profissāo:

- Familia

Nome do responsável:

Endereço:

Data de Nascimento:

$1+1$

Profissāo:

Escolaridade

Diagnóstico

Estado civil:

Profissionais envolvidos:

Medicamentos:

Motivo da consulta(Lazer, AVD's, sono, dificuldades, vida social, vida afetiva, alimentaçăo, outros ...):

Assinatura do responsável pela avaliação 
FICHA DE EXAME AUDIOLÓGICO OCUPACIONAL

\begin{tabular}{|l|}
\hline DEPENDENCIA \\
\hline EXAME MEDICO \\
\hline$\square$ PERIODICO \\
\hline RETORNO AO TRABALHO \\
\hline MUDANÇA DE FUNÇÃO \\
\hline$\square$ DEMISSIONAL \\
\hline
\end{tabular}

\begin{tabular}{|l|l|l|}
\hline DADOS PESSOAIS & \\
\hline NOME & MATRICULA \\
\hline DATADE AOMIISSRO & DATADE MASCIMENTO & COR \\
\hline CARGO & SIGLADALOTACAO & \\
\hline FUNCLAO & LOTACAO & \\
\hline
\end{tabular}

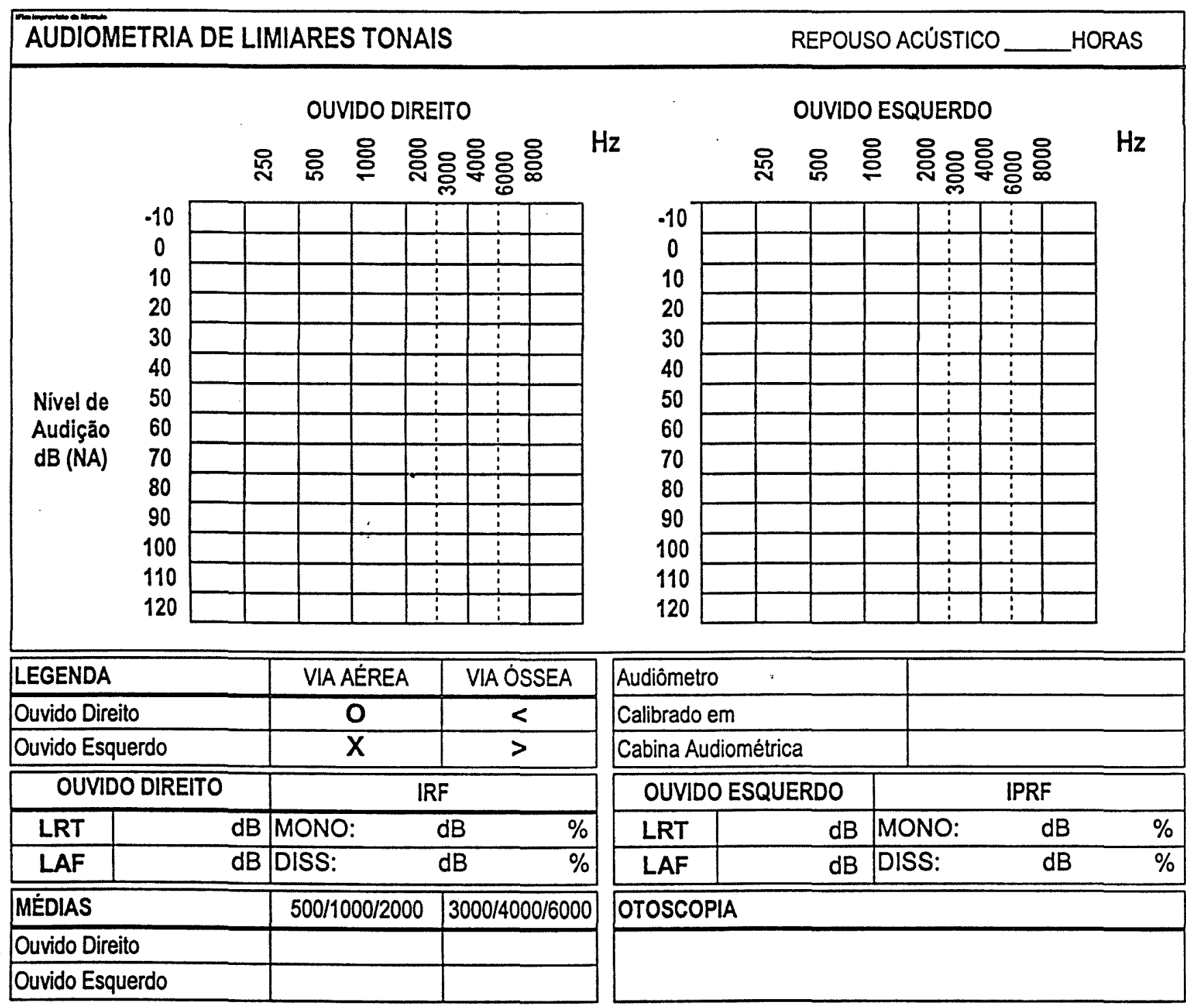

CONCLUSÕES

\section{OBSERVAÇÕES}


ANAMNESE AUDIOLÓGICA

1. Está em repouso auditivo ?

Quantas horas?

2. Alguém na familia tem problema de surdez?

Quem?

SIM NÃO

3. Teve problemas de audição?

Quais?

SIM

NÃO

4. Sente dores no ouvido, zumbido sensação de pressăo ou tontura freqüente?

SIM

5. Sofreu algum trauma no ouvido ou crânio?

SIM

NÃO

6. Fez ou faz uso de medicamentos com frequeência ou por longo periodo de tempo?

Qual medicamento?

Tempo de Uso

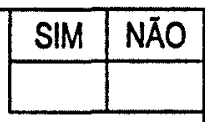

Finalidade

7. Trabalhou cm outras áreas da cmpresa?

Quals ?

Por quanto tempo ?

8. Tem contato com ruido no trabalho ?

Quanto tempo por dia?

9. Faz outras atividades ligadas ao ruido fora do trabalho?

SIM NAO

10. Tem contato com produtos quimicos tais como: solventes, vapores metálicos, gases asfixiantes, etc...

Quais ?

Esta exposto a vibraçōes ?

11. Usa protetor auricular? Qual?

Quando costuma usar?

SIM $N \bar{A} \bar{O}$

12. Acha que escuta bem?

OBSERVAÇÕES

Em empregos anteriores teve contato com: Ruido, Vibraçåo, Produlos qulmicos.... Trabalhou durante quanto tempo? 
TIMPANOGRAMA
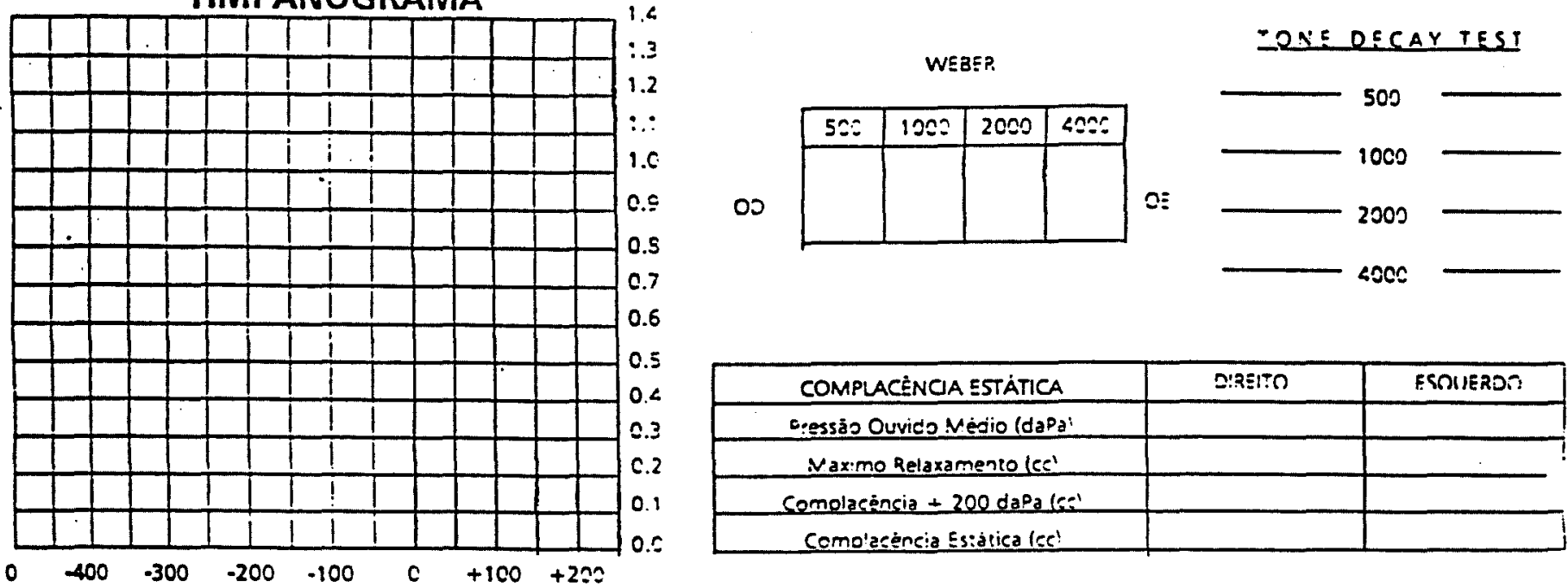

\begin{tabular}{|c|c|c|}
\hline COMPLACĖNCIA ESTÁTICA & S!REITO & ESOUERDA \\
\hline cuessāo Ouvido Nédio (dapa: & & \\
\hline Vax:mo Relaxamento les' & & \\
\hline Comolacencie +200 daPa $/ c=$ & & \\
\hline Como'ecéncia Es:ática lce! & & \\
\hline
\end{tabular}

\begin{tabular}{|c|c|c|c|c|c|c|c|c|c|c|}
\hline \multicolumn{11}{|c|}{ REFLLXO ESTAPEDIAVO } \\
\hline FREO. & $\begin{array}{l}\text { IMLAR } \\
\text { OD }\end{array}$ & $\begin{array}{l}\text { AF. D } \\
\text { CONTA }\end{array}$ & DIFE? & $A=C D$ & $D \equiv C^{2}$ & UNALA & $\begin{array}{c}A^{\prime}= \\
\cos { }^{2}=\end{array}$ & Q!:!:? & $\begin{array}{l}A=\ldots \\
\text { ADE. }\end{array}$ & DECAV \\
\hline 500 & & & & & & & & & & \\
\hline 1000 & & & & & & & & & & \\
\hline 2000 & & & & & & & & & & \\
\hline 4000 & & & & & & & & & & \\
\hline
\end{tabular}

Resulkado: 


\section{Termo de consentimento}

Pesquisa: "Condições de Vida dos Catadores de Caranguejo do Município de Vitória (ES)”. Pesquisadora: Rozangela Pereira Marins, administradora (CRA/ES 0806).

Objetivo: Identificar aspectos sócio-econômico e culturais dos catadores de caranguejo e de suas famílias e avaliar os agravos à saúde dos catadores de caranguejo, decorrentes do esforço despendido na locomoção, captura e transporte dos caranguejos dentro do manguezal e também das condições insalubres do ambiente de trabalho.

Procedimentos: A coleta de dados será realizada por meio de entrevistas com todos os catadores de caranguejo, que atuam diretamente nessa atividade.

A participação não será obrigatória.

Será garantido o anonimato do (a) entrevistado (a) e a confidencialidade das informações.

A pesquisadora compromete-se a esclarecer todas as dúvidas acerca da pesquisa, assim como divulgar os resultados para os participantes após o término da mesma.

Declaro que, após ter sido convenientemente esclarecido (a) pela pesquisadora, eu, , consinto em participar desta pesquisa,

estando ciente de que, com minha autorização, a entrevista será gravada.

Vitória, de de 2003.

Assinatura do participante

Assinatura da pesquisadora 


\section{- Entrevistas espontâneas:}

\begin{tabular}{|c|c|}
\hline 1) Qual o nome do senhor? & $\begin{array}{l}\text { 1- Jorge, } 40 \text { anos. } \\
\text { 2- Marcos, } 23 \text { anos. } \\
\text { 3- Sérgio, } 42 \text { anos. }\end{array}$ \\
\hline $\begin{array}{l}\text { 2) Há quanto tempo o } \\
\text { senhor esta na cata do } \\
\text { caranguejo? }\end{array}$ & $\begin{array}{l}\text { 1- Na cata do caranguejo ta com vai fazer } 30 \text { anos. } \\
\text { 2- Desde } 1996 . \\
\text { 3- Desde } 14 \text { anos, vou fazer } 43 \text { anos agora. }\end{array}$ \\
\hline $\begin{array}{l}\text { 3) Quanto tempo o senhor } \\
\text { fica no mangue? }\end{array}$ & $\begin{array}{l}\text { 1- Dependendo da maré, } 6 \text { horas à } 8 \text { horas, depende da maré, na } \\
\text { maré grande } 4 \text { horas, na maré morta dá pra ficar até } 8 \text { horas. } \\
2-6 \text { horas. } \\
\text { 3- } 5 \text { horas. }\end{array}$ \\
\hline $\begin{array}{l}\text { 4) Quando não } \\
\text { mangue esta no } \\
\text { atividade? Qual? }\end{array}$ & $\begin{array}{l}\text { 1- Sim, minha atividade é fazer um biscate, quando acho uma } \\
\text { mudança para fazer, é o que eu tenho que fazer. Ultimamente eu } \\
\text { não estou podendo fazer, que minha mulher faleceu e eu tenho que } \\
\text { cuidar dos meninos. Estou mais pescando de noite. } \\
\text { 2- O que tiver a disposição para mim, oficina de serralheria, } \\
\text { supermercado, qualquer coisa, ajudante de pedreiro. } \\
\text { 3- Não. }\end{array}$ \\
\hline $\begin{array}{l}\text { 5) Quando vai ao mangue, } \\
\text { costuma ir sozinho? }\end{array}$ & $\begin{array}{l}\text { 1- Não, os meus meninos me ajudam a vender, mas o meu eu } \\
\text { vendo sozinho em casa. Meu produto é bom e eu quase não tenho } \\
\text { que sair na rua. } \\
\text { 2- Sempre vou com um, nunca vou sozinho. } \\
\text { 3- Quando tem algum parceiro agente vai, mas geralmente vou } \\
\text { mais só. }\end{array}$ \\
\hline $\begin{array}{l}\text { 6) } 0 \text { senhor costuma } \\
\text { beber? }\end{array}$ & $\begin{array}{l}\text { 1- Bebo uma cervejinha, uma pinga. Quando chego da maré bebo } \\
\text { mesmo, não adianta mentir. } \\
\text { 2- Não. } \\
\text { 3- De vez em quando eu bebo. }\end{array}$ \\
\hline $\begin{array}{l}\text { 7) Na opinião do senhor o } \\
\text { que é beber socialmente? }\end{array}$ & $\begin{array}{l}\text { 1- É beber com comportamento, saber o que esta fazendo, erguer a } \\
\text { cabeça e fazer o que é certo. E não perder a cabeça, ter } \\
\text { responsabilidade naquilo que esta fazendo. } \\
\text { 2- Não respondeu. } \\
\text { 3- Quem bebe uma vez ou outra, fim de semana não todo dia. }\end{array}$ \\
\hline
\end{tabular}




\begin{tabular}{|c|c|}
\hline $\begin{array}{l}\text { 8) Quantas horas o senhor } \\
\text { dorme por dia? }\end{array}$ & $\begin{array}{l}\text { 1- O máximo que durmo é } 8 \text { horas. } \\
\text { 2- Umas } 8 \text { horas. } \\
\text { 3- } 8 \text { horas por aí. }\end{array}$ \\
\hline $\begin{array}{l}\text { 9) Como } \dot{e} \quad 0 \\
\text { relacionamento do senhor } \\
\text { com os outros catadores? }\end{array}$ & $\begin{array}{l}\text { 1- Pra mim é ótimo, todos são meus amigos, nós somos um irmão } \\
\text { pelo outro, quando eu posso ajudar a eles eu ajudo, quando eles } \\
\text { pode me ajudar, eles me ajuda também. } \\
\text { 2- A melhor possível, não tenho inimizade com ninguém, é } \\
\text { tranqüilo no meio da rapaziada. } \\
\text { 3- A gente tem uma amizade né, tem que ter amizade, não tem } \\
\text { como não ter. }\end{array}$ \\
\hline $\begin{array}{l}\text { 10) Qual a opinião do } \\
\text { senhor em relação à } \\
\text { associação dos catadores } \\
\text { de caranguejos? }\end{array}$ & $\begin{array}{l}\text { 1- A minha opinião sobre a associação seria uma coisa assim, para } \\
\text { um ajudar o outro, sem prejudicar o outro, mas quando eu cresci e } \\
\text { vi que já cresceram o olho em dinheiro, fiquei de sair fora, e sai } \\
\text { fora. Que eu queria fazer um trabalho pra um ajudar o outro, que } \\
\text { acho que associação é uma entidade humana pra um ajudar o } \\
\text { outro, mas quando eles começaram a crescer os olhos em dinheiro } \\
\text { eu peguei e saí fora disso ai. Meu objetivo era ajudar eles. } \\
\text { 2- Na minha opinião, não teve uma associação que teve firmeza } \\
\text { para ajudar os catadores, sempre só entrou ladrão, que pegava a } \\
\text { merrequinha que tinha lá dentro, até hoje não deu certo não. } \\
\text { 3- Tem que ter, é bom para organizar. }\end{array}$ \\
\hline $\begin{array}{llrr}11) & \text { Como } & \text { é } & \text { o } \\
\text { relacionamento do grupo } \\
\text { de catadores com } & \text { a } \\
\text { prefeitura Municipal de } & \text { Mitória? }\end{array}$ & $\begin{array}{l}\text { 1- Nós com a prefeitura muito bom, a prefeitura no meu tempo o } \\
\text { que pode ajudar nóis. Luiz Paulo, tudo que pedi a ele, me ajudou } \\
\text { em tudo, entendeu, muito bom, por mim ele não saía nunca, ele é } \\
\text { uma pessoa ótima. } \\
\text { 2- Tudo beleza, a prefeitura ajuda agente com essas limpezas. Só } \\
\text { tenho a falar bem dela. } \\
\text { 3- Rapaz, nenhuma. }\end{array}$ \\
\hline $\begin{array}{l}\text { 12) O projeto caranguejo } \\
\text { troure algum beneficio } \\
\text { para os catadores de } \\
\text { caranguejos? }\end{array}$ & $\begin{array}{l}\text { 1- Trouxe sim, porque eles sempre vem procurando, eles ajudam, } \\
\text { igual hoje a gente recebe a defesa, isso ai já faz parte do órgão } \\
\text { federal. } \\
\text { 2- Trouxe esse cadastro da gente que não era cadastrado nem nada, } \\
\text { a prefeitura foi e entrou para ajudar agente, a limpeza do } \\
\text { manguezal que é uma renda que nós não tínhamos. } \\
\text { 3- Não respondeu. }\end{array}$ \\
\hline
\end{tabular}

